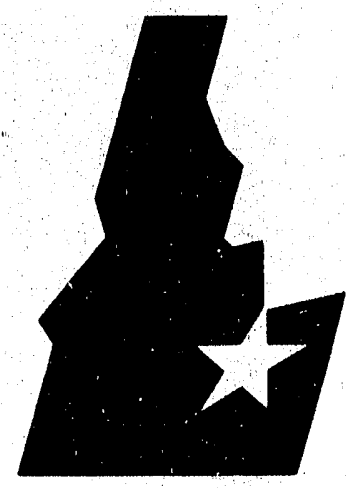

Idaho

National

Engineering

Laboratory

Managed

by the U.S.

Department

of Energy.
EGG-WTD-10035

February 1992

$$
\text { Appe? }
$$

\section{Assessment of Incineration and} Melting Treatment Technologies for RWMC Buried Waste

\author{
R. Gelmer \\ T. Hertzler \\ R. Gillins \\ G. L. Anderson
}

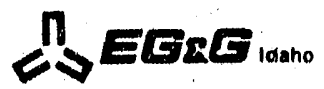

Work performed under DOE Contract No. DE-ACO7-761001570 
This document contains new concepts or the author(s) interpretation of new calculations and/or measurements; accordingly, EG\&G Idaho, Inc. is required by the United States Government to include the following disclaimer:

\section{DISCLAIMER}

This report was prepared as an account of work sponsored by an agency of the United States Government. Neither the United States Government nor any agency thereof, nor any of their employees, makes any warranty, express or implied, or assumes any legal liability or responsibility for the accuracy, completeness, or usefulness of any information, apparatus, product or process disclosed, or represents that its use would not infringe privately owned rights. Reterences herein to any specific coinmercial product, process, or service by trade name, trademark, manufacturer, or otherwise, does not necessarily constitute or imply its endorsement, recommendation, or favoring by the United States Government or any agency thereof. The views and opinions of authors expressed herein do not necessarily state or reflect those of the United States Government or any agency thereot. 


\title{
Assessment of Incineration and Melting Treatment Technologies for RWMC Buried Waste
}

\author{
R. Geimer ${ }^{\mathrm{a}}$ \\ T. Hertzler ${ }^{\mathrm{a}}$ \\ R. Gillins ${ }^{a}$ \\ G. L. Anderson \\ Published February 1992 \\ Idaho National Engineering Laboratory \\ EG\&G Idaho, Inc. \\ Idaho Falls, Idaho 83415

\begin{abstract}
Prepared for the
U.S. Department of Energy

Office of Environmental Restoration and Waste Management

Under DOE Idaho Field Office

Contract DE-AC07-76ID01570
\end{abstract}

a. Prepared for EG\&G Idaho, Inc., by Science Applications International Corporation, 2300 N. Yellowstone Highway, Idaho Falls, Idaho 83401. 
Assessment of Incineration and Melting Treatment Technologies for RWMC Buried Waste

Prepared by:

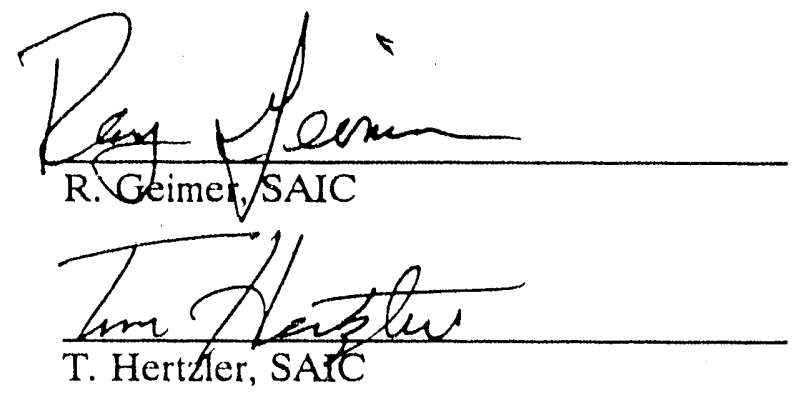

REFill

R. Gillins, SAIC

Reviewed by:

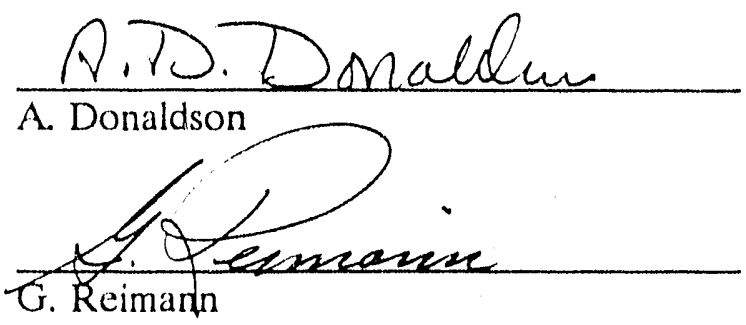

Reviewed and Approved by:

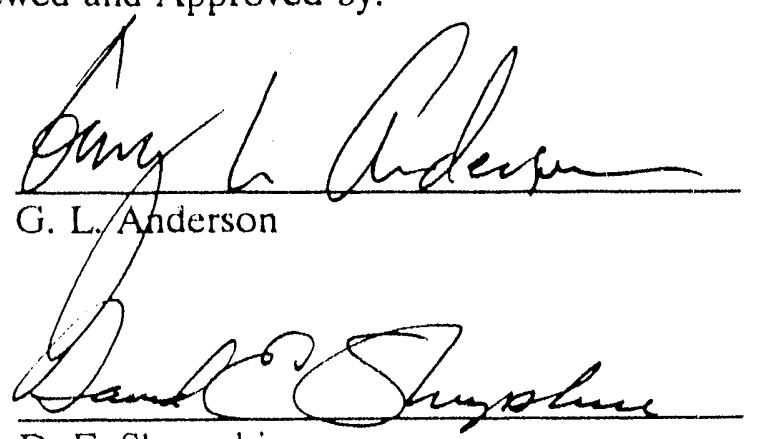

D. E. Shropshire $\frac{2 / 27 / 92}{\text { Date }}$

$2 / 27 / 92$

Date

$2 / 27 / 92$

Date $\frac{2 / 29 / 92}{\text { Date }}$
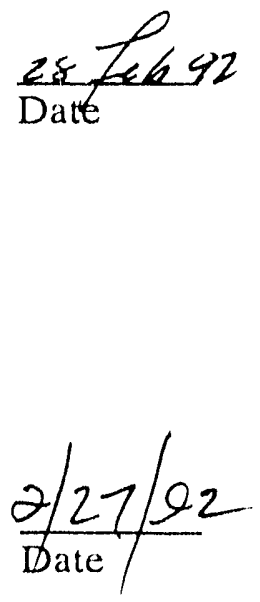

$2 / 27 / 52$

Date 


\begin{abstract}
This report provides an identification, description, and ranking evaluation of the available thermal treatment technologies potentially capable of treating the Idaho National Engineering Laboratory Radioactive Waste Management Complex (RWMC) buried mixed waste. The ranking evaluation focused separately upon incinerators for treatment of combustible wastes and meiters for noncombustible wastes. The highest ranked incinerators are rotary kilns and controlled air furnaces, while the highest ranked melters are the hearth configuration plasma torch, graphite electrode arc, and joule-heated melters.
\end{abstract}




\section{EXECUTIVE SUMMARY}

This study was completed as part of the Thermal Processing Technology project being conducted by the Waste Technology Development Department of EG\&G Idaho, Inc. It was conducted as a follow-up to a separate study conducted by EG\&G Idaho, referred to as the Preliminary Systems Design Study (SDS). ${ }^{1}$ The SDS provided an overall evaluation of a variety of remediation systems strategies for treatment of buried waste at the Radioactive Waste Management Complex (RWMC) of the Idaho National Engineering Laboratory (INEL). Many of the SDS higher rated process systems strategies were based on retrieving the waste material and processing it into a more stabie and acceptable state through some form of thermal treatment.

The SDS study identified an ex situ process strategy that would provide for separation of retrieved waste into a bulk soil waste stream, a bulk metals waste stream, a combustible waste stream, and a noncombustible waste stream. The SDS postulates that the combustible stream would be best treated in an incinerator technology and the noncombustible waste stream (and possibly the bulk soil stream) in a high temperature melter/vitrifer technology. The SDS further determined that this is one of the more desirable of the potential ex situ treatment options.

The purpose of the study reported here is to identify, describe, evaluate, and rank the potential thermal treatment technologies that could be employed in either the incineration of the RWMC combustible waste or the melt processing of noncombustible waste as separate waste streams. An earlier thermal technologies identification and screening study ${ }^{2}$ was used as a starting point. This earlier study had already identified and ranked available thermal technologies against application to bulk average mixed waste and soil streams representative of the RWMC buried wastes. Technologies identified in this earlier study as "not applicable to RWMC buried waste" were not considered further.

This study provides additional consideration of the likely composition of the separated combustible and noncombustible waste streams against which to separately rank the incinerators and melters, respectively. A technology evaluation (scoring) approach was used, similar to that in the earlier study, to score each technology on a list of attributes, then rank order the technologies by total score. Although the same list of attributes was used for both incinerators and melters, each attribute was made up of criteria (sub-attributes or contributing features) which were somewhat different for incinerators and melters (see Tables 3 and 4).

The results of the evaluation and ranking of the incinerators and melters relative to the separated RWMC combustible and noncombustible waste stream applications are shown in Table 1.

It should be noted that the ranking results simply indicate which types of incinerators and melters are likely the best suited for the RWMC waste applications. It is quite possible that any of these technologies could be made to satisfactorily perform the required combustion and melting stabilization functions to some degree given sufficient engineering investment. It is also true that 
Table 1. Technology rankings for incinerators and melters.

\begin{tabular}{llll}
\hline & \multicolumn{2}{c}{ Melters } \\
\hline Rotary Kiln & 74 & Plasma torch hearth & 75 \\
Controlled air & 73 & Graphite electrode hearth & 73 \\
Slagging kiln & 66 & Joule-heated & 68 \\
Fluidized bed & 62 & Molten metal & 60 \\
Multiple hearth & 53 & Fossil fueled hearth & 59 \\
Cyclone incinerator & 43 & Graphite electrode shaft & 45 \\
Cyclone melter & 33 & Slagging kiln & 41 \\
Molten salt & 24 & Microwave & 40 \\
& & Plasma torch shaft & 38 \\
& & Cyclone melter & 36
\end{tabular}


none of the technologies have been demonstrated fully on the transuranic (TRU)-contaminated wastes and soils which make up the RWMC remediation problem.

In general, it can be stated that commercial incineration technologies for combustible wastes have been well developed over the last two decades. Incinerators are well understood for the type of combustible waste materials applications being considered at RWMC, with the recognition that incineration of TRU-contaminated wastes will require special features to ensure proper contamination and criticality control. Many incineration systems have been constructed and are now operating in hazardous and low-level radioactive waste treatment applications throughout the world.

Melting technologies can be operated such that they pyrolyze or oxidize (combust) an organic waste fraction; however, incinerators have been designed and developed specifically for this purpose, and will function much more effectively than a melter in this regard. There are also other benefits to preprocessing organics in an incineration step and processing the residual inorganics in the melter process to achieve the final waste form. Such a strategy will maintain a minimum offgas volume from the melter process, thus allowing melter afterburners and offgas trains to be small and compact systems. This creates advantages in equipment and facility design, process complexity and controllability, and perhaps even in perception. These advantages disappear rapidly with increasing organic loading in the waste, as offgas system design will then be driven by the offgas products from the processing of the organics. In addition, elimination of organics allows a greater flexibility of operation of the melter process to control chemistry (redox conditions) in the melt.

The melter technology rankings are largely driven by the operating temperature capability, robustness to feedstock variations, limitations of offgas generators, and related industrial applications experience base. The melter technologies have a considerable experience base within the pyrometallurgical industry and the glass industry, which indicate they are generally time-proven technologies for related materials applications. The specific application of the melter technologies for stabilization of radioactive wastes has, however, largely been limited to a few well defined highlevel waste glass compositions (using lower temperature joule-heated melters). There are, therefore, many more open questions regarding the applications of melter technologies to the processing of RWMC TRU-contaminated wastes and soils. Other studies have been conducted by EG\&G Idaho to more thoroughly evaluate the leading melter technologies (see Reference 4). 


\section{CONTENTS}

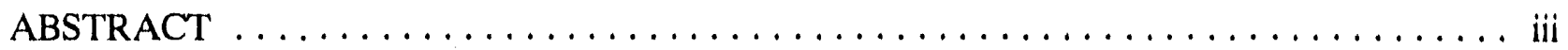

EXECUTIVE SUMMARY $\ldots \ldots \ldots \ldots \ldots \ldots \ldots \ldots \ldots \ldots \ldots \ldots \ldots$

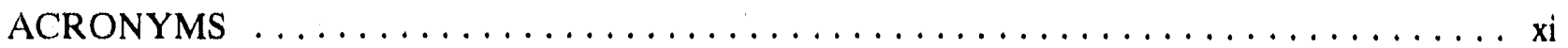

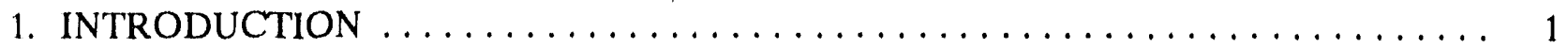

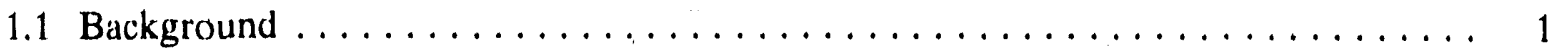

1.2 Categorization of Thermal Treatment Technologies $\ldots \ldots \ldots \ldots \ldots \ldots \ldots$

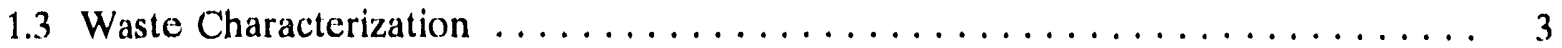

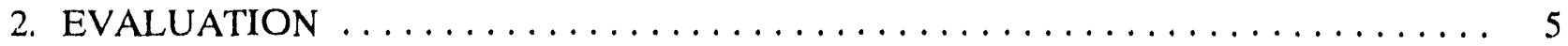

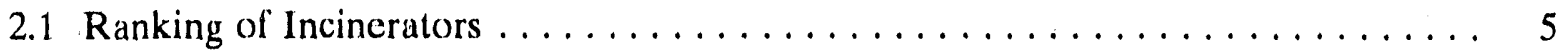

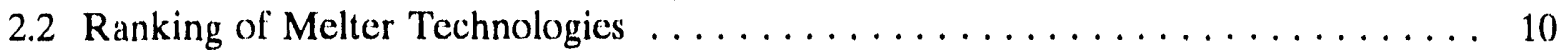

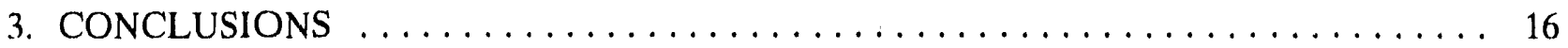

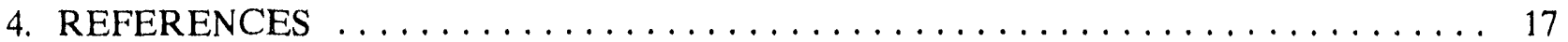

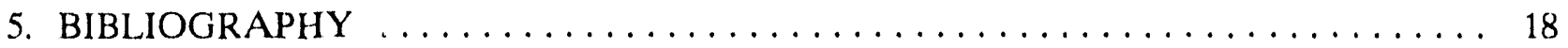

Appendix A--Basis for Determination of Waste Stream Components . . . . . . . . . . A-1

Appendix B--Evaluation Methodology $\ldots \ldots \ldots \ldots \ldots \ldots \ldots \ldots \ldots \ldots \ldots \ldots \ldots$

Appendix C-Evaluation of Technologies $\ldots \ldots \ldots \ldots \ldots \ldots \ldots \ldots \ldots \ldots \ldots \ldots$

Appendix D.-Technology Summary Descriptions $\ldots \ldots \ldots \ldots \ldots \ldots \ldots \ldots \ldots \ldots$

\section{TABLES}

1. Technology rankings for incinerators and melters $\ldots \ldots \ldots \ldots \ldots \ldots \ldots \ldots$ vi

2. Thermal treatment technologies being evaluated in this study $\ldots \ldots \ldots \ldots \ldots \ldots$

3. Scoring explanation for incinerators (combustible wastes) $\ldots \ldots \ldots \ldots \ldots \ldots$

4. Scoring explanation for melters (noncombustible wastes) $\ldots \ldots \ldots \ldots \ldots \ldots$

5. Results from the evaluation of incincration technologies $\ldots \ldots \ldots \ldots \ldots \ldots \ldots \ldots$

6. Results from the evaluation of melter technologics $\ldots \ldots \ldots \ldots \ldots \ldots \ldots \ldots \ldots \ldots$ 


\section{ACRONYMS}

CERCLA Comprehensive Environment Responses Compensation, and Liability Act

DOE Department of Energy

EPA Environmental Protection Agency

INEL Idaho National Engineering Laboratory

JHM joule-heated melter

RCRA : Resource Conservation and Recovery Act

RFP Rocky Flats Plant

RWMC Radioactive Waste iManagement Complex

SDS Systems Design Study

TRU transuranic

TSA Transuranic Storage Area 


\section{Assessment of Incineration and Melting Treatment Technologies for RWMC Buried Waste}

\section{INTRODUCTION}

\subsection{Background}

Beginning in 1952, low-level radioactive waste generated at the Idaho National Engineering Laboratory (INEL) was buried in the Subsurface Disposal Area (SDA) at the INEL's Radioactive Waste Management Complex (RWMC). In 1954 the INEL began receiving for burial low-level alpha emitting waste [refered to as alpha contaminated or transuranic (TRU) waste]. The low-level and transuranic wastes were disposed of in shallow pits and trenches until 1972. After this time the practice was stopped and TRU wastes were segregated and stored at the Transuranic Storage Area (TSA) of the RWMC.

Most of the transuranic-contaminated wastes were from the Rocky Flats Plant (RFP) nuclear weapons production/operation and also contained Resource Conservation and Recovery Act (RCRA) hazardous organics and toxic metals. Wastes containing both 'radioactive and hazardous constituents are designated as "mixed wastes."

In 1989 the INEL was placed on the National Priority List which mandates remediation of the SDA consistent with t? e Comprehensive Environmental Response, Compensation, and Liability Act (CERCLA) decision process.

A preliminary systems design study ${ }^{1}$ was recently completed by EG\&G Idaho, Inc., which provides an overall evaluation of remediation strategies for the RWMC. A large number of strategies were defined and their overall performance was evaluated. Many of the higher-rated strategies were based upon retrieving and processing the waste material into a more stable and acceptable form using thermal treatment process technologies.

One of the specific remediation strategies evaluated in the SDS involves treatment of the waste in the "as-received" condition, i.e., without any segregation of components. An earlier thermal technologies screening study ${ }^{2}$ was performed to rank the capability of various thermal treatment technologies in processing the "as-received" (bulk average) waste composition.

The purpose of the present study is to identify and evaluate potential thermal treatment technologies for the SDS strategy in which the waste materials are assumed to be separated into a bulk soil waste stream, a bulk metals waste stream, a combustibles waste stream, and a noncombustible waste stream. In particular, this study examines the available incineration 
technologies for the combustible waste stream, and the available melter/vitrifer technologies for the noncombustible waste stream (which may include some portion of the TRU-contaminated soils waste stream).

This study proceeds in a manner similar to the thermal technologies screening study (see Reference 2). Thermal technologies previously identified as "not applicable to RWMC buried waste" in that study are not considered further. A technology evaluation (scoring) approach is used similar to that of the earlier study, but modified appropriately for considering incinerators and melters for separate combustible and noncombustible waste streams, respectively.

\subsection{Categorization of Thermal Treatment Technologies}

Thermal treatment technologies are defined as processes that utilize heat energy to physically and/or chemically transform a waste material into a less hazardous form (less toxic, less ignitable, less reactive, less mobile, etc.). Thermal processes can be categorized by process temperature, primary waste types treated, configurations, etc. Low temperature thermal process technologies are typically referred to as thermal desorbers or roasters. They are in:ended to volatilize (evaporate) and, thus, "desorb" or separate the hazardous organics from the waste material. The desorbed organics may then be incinerated in a separate process step. Although the; may at some point be of interest in an overall thermal treatment system for RWMC wastes, the low temperature desorber will not be considered further in this study.

High temperature processes are typically aimed at pyrolization or combustion of hazardous organics, or melting/vitrification for stabilization of hazardous noncombustibles (toxic metals, etc.). For the purposes of this study, high temperature processes will be categorized either as incinerators or melters.

Incineration technologies will be defined as those technologies that were principally designed for the treatment of moderate to highly combustible wastes (and thus high heat release rates). Incineration provides substantial volume reduction through bulk organic material destruction, and provides for the chemical transformation of hazardous organic materials. Incinerators are devices that have been specifically designed to oxidize (combust) the organic fraction of the waste, leaving a largely inert residual (ash), generally without regard to the physical or chemical form of that residual. An incinerator can serve to prepare waste material for subsequent feed to a melter process.

Melter technologies will be defined as those high temperature furnaces that have been specifically designed to alter the chemical and/or physical form of the material by means of creating a molten intermediate product in order to change the waste form into a highly leachresistant final waste form for permanent disposal. Such technologies, while also being capable of pyrolization or combustion of some amounts of organic materials, are generally intended for use in treating (stabilizing) noncombustible materials as a glass/ceramic slag product. 
Table 2 displays the thermal technologies being evaluated in this study, grouped into categories based on the waste type they were primarily designed to process. The slagging kiln and cyclone melter technologies are two technologies that will be evaluated in both categories. These technologies are adaptations of an incineration process, and are thus designed primarily to accept and treat combustible waste material. They can, however, also create a molten product (slag or vitrified ash) to improve the stability of the residual solid material, and thus partially fit the melter definition as well. A description of each of the technologies considered is provided in Appendix B.

\subsection{Waste Characterization}

In order to evaluate a thermal process for treatment of RWMC buried waste, a description of the separate waste streams to be treated is required. Appendix A provides a description of the RWMC wastes and defines waste streams for the incincrator and melter evaluations consistent with the top-level screening nature of this study.

The waste feed stream for the evaluation of incinerator technologies is basically determined to consist of typical combustible waste materials (paper, plastic, wood, cloth, cardboard, rubber, and oil), but also possibly organically contaminated silicate and nitrate sludges, inorganic aqueous sludges for a dewatering step, any soil heavily contaminated with organic solvents, and some tramp metals. The bulk metals and soil will have been separated out for separate treatment.

The waste feed stream for evaluation of the melter technologies is determined to consist of the residual ash from the incinerator process (inciuding soils and tramp metals), the Rocky Flats Plant sludges, a fraction of the soils not sent to the incinerator, brick, concrete, and glass wastes. 
Table 2. Thermal treatment technologies being evaluated in this study.

\begin{tabular}{ll}
\hline Incinerators & \multicolumn{1}{c}{ Melters } \\
\hline & \\
Rotary kiln & Fossil fueled hearth \\
Controlled air & Plasma torch hearth \\
Fluidized bed & Graphite electrode hearth \\
Molten salt & Fossil fucled shaft \\
Cyclone & Plasma torch shaft \\
Multiple hearth & Graphite electrode shaft \\
Slagging kiln & Joule-heated melter \\
Cyclone melter & Molten metal bath \\
& Microwave \\
& Slagging kiln \\
& Cyclone melter \\
\hline
\end{tabular}




\section{EVALUATION}

In order to evaluate and rank order the different thermal technologies within each of their categories, a standard set of ranking criteria was defined. For the purpose of this study, the basic evaluation methodology advanced in Reference 2 was used and modified for the specific concerns of this study. That methodology involved the definition of a number of characteristics, or attributes, that are important when considering application of a particular thermal treatment process. The technologies were assessed on their performance with respect 10 these attributes, and a relative numerical score assigned. Individual attribute scores are further assigned a weighting factor based on the relative importance of that attribute. Total scores of the technologies were compared to rank order, highest being most suitable. Appendix B provides details on how this evaluation strategy was defined. A separate criteria matrix was established for each of the two technology categories to account for these differences. These matrices are displayed in Tables 3 and 4.

Appendix $\mathrm{C}$ provides a detailed discussion of the performance of each of the technologies as it was evaluated against the specific criteria which define each attribute. The performance rating of incinerators is presented first, followed by the rating of melter technologies. Within each treatment category, the evaluation discussion is organized by attribute. This allows a ready comparison of the performance of one technology relative to the others for a given particular attribute. The results of the ranking evaluations are presented in the remainder of this section.

\subsection{Ranking of Incinerators}

Table 5 is a summary of the scores assigned for each attribute for each of the incineration technologies. These results indicate a wide range of applicability of the various incineration processes that are available. Several of the technologies were rated as having a high potential for their use in treating the RWMC combustible waste. Since there appears to be a very close rating among the top four rated technologies, no one technology stands out as the obvious best choice.

The two incineration technologies that appear to have the highest potential for successful application to combustible waste streams at the RWMC are the rotary kiln and the controlled air incincrators. Each has advantages and disadvantages in differing areas.

The rotary kiln is by far the most versatile incineration technology, and will be able to accept virtually any material that can be introduced as a feed, including large fractions of noncombustibles. Whole intact drums of waste can be aceptable feed, as is routinely done in many large commercial rotary kiln applications. Rotary kilns have been used in many site restoration projects similar to the RWMC remediation, involving the incincration of organic 
Table 3. Scoring explanation for incinerators (combustible wastes).

\begin{tabular}{|c|c|c|c|c|}
\hline WI. & Altribute & Calegory & Score & Description \\
\hline \multirow[t]{4}{*}{15} & $\begin{array}{l}\text { Level of development and avallability } \\
\text { (LDA) }\end{array}$ & $\begin{array}{l}\text { Development } \\
\text { stage }\end{array}$ & $\begin{array}{l}1 \\
2\end{array}$ & $\begin{array}{l}\text { Demonstration phase } \\
\text { Operational phase }\end{array}$ \\
\hline & & $\begin{array}{l}\text { 'lested on } \\
\text { waste type }\end{array}$ & $\begin{array}{l}0 \\
1\end{array}$ & $\begin{array}{l}\text { No } \\
\text { Yes }\end{array}$ \\
\hline & & $\begin{array}{l}\text { Commercial } \\
\text { avallability }\end{array}$ & $\begin{array}{l}0 \\
1\end{array}$ & $\begin{array}{l}\text { Not commercially avallable } \\
\text { Commercially available }\end{array}$ \\
\hline & & lime proven & $\begin{array}{l}0 \\
1\end{array}$ & $\begin{array}{l}\text { Not lime proven } \\
\text { 'lime proven }\end{array}$ \\
\hline \multirow[t]{3}{*}{30} & Versatility (VRSL) & $\begin{array}{l}\text { Fraction } \\
\text { applicable }\end{array}$ & $\begin{array}{l}1 \\
2 \\
3\end{array}$ & $\begin{array}{l}\text { Limited applicability } \\
\text { Applicable to most of waste } \\
\text { applicable to all waste types }\end{array}$ \\
\hline & & $\begin{array}{l}\text { Screening } \\
\text { requirements }\end{array}$ & $\begin{array}{l}0 \\
1\end{array}$ & $\begin{array}{l}\text { High } \\
\text { Low }\end{array}$ \\
\hline & & $\begin{array}{l}\text { Pretreatment } \\
\text { requirements }\end{array}$ & $\begin{array}{l}0 \\
1\end{array}$ & $\begin{array}{l}\text { High } \\
\text { Low }\end{array}$ \\
\hline \multirow[t]{3}{*}{10} & Residual solid product (RSP) & Org destr. & $\begin{array}{l}1 \\
2\end{array}$ & $\begin{array}{l}\text { Low burnoul } \\
\text { High burnout }\end{array}$ \\
\hline & & Handling & $\begin{array}{l}0 \\
1 \\
2\end{array}$ & $\begin{array}{l}\text { Complex handling considerations } \\
\text { Moderate handling considerations } \\
\text { Minor handling considerations }\end{array}$ \\
\hline & & Volume reduction & $\begin{array}{l}0 \\
1\end{array}$ & $\begin{array}{l}\text { Low volume reduction potential } \\
\text { High volume reduction potential }\end{array}$ \\
\hline \multirow[t]{3}{*}{15} & Effluents (EFLI) & Volunse & $\begin{array}{l}1 \\
2\end{array}$ & $\begin{array}{l}\text { High volumes } \\
\text { Low volumes }\end{array}$ \\
\hline & & Particulate & $\begin{array}{l}0 \\
1\end{array}$ & $\begin{array}{l}\text { Iligh particulate generation } \\
\text { low particulate generation }\end{array}$ \\
\hline & & Other considerations & $\begin{array}{l}0 \\
1 \\
2\end{array}$ & $\begin{array}{l}\text { Extensive offyas considerations } \\
\text { Moderate offyas considerations } \\
\text { few offgas cronsiderations }\end{array}$ \\
\hline \multirow[t]{4}{*}{25} & $\begin{array}{l}\text { Operational considerations (OPS) } \\
\text { (Divide score by } 2 \text { ) }\end{array}$ & Complexity & $\begin{array}{l}1 \\
2 \\
3\end{array}$ & $\begin{array}{l}\text { Highly complex process } \\
\text { Moderately complex process } \\
\text { Simple process }\end{array}$ \\
\hline & & Health and safety & $\begin{array}{l}1 \\
2 \\
3\end{array}$ & $\begin{array}{l}\text { Extensive considerations } \\
\text { Moderate considerations } \\
\text { fiew considerations }\end{array}$ \\
\hline & & Maintenance & $\begin{array}{l}0 \\
1 \\
2\end{array}$ & $\begin{array}{l}\text { Iligh maintenance regs. } \\
\text { Moderate maintenance reqs. } \\
\text { I dow maintenance reqs. }\end{array}$ \\
\hline & & Throughput & $\begin{array}{l}0 \\
1 \\
2\end{array}$ & $\begin{array}{l}\text { Low potential } \\
\text { Moderale potential } \\
\text { lligh poltential }\end{array}$ \\
\hline 5 & $\cos t$ & Capital & $\begin{array}{l}1 \\
3 \\
5\end{array}$ & $\begin{array}{l}\text { High } \\
\text { Moderale } \\
\text { Low }\end{array}$ \\
\hline
\end{tabular}


Table 4. Scoring explanation for melters (noncombustible wastes).

\begin{tabular}{|c|c|c|c|c|}
\hline Wt. & Altribute & Calcgory & Score & Description \\
\hline \multirow[t]{5}{*}{10} & $\begin{array}{l}\text { Level of development and availability } \\
\text { (LDA) }\end{array}$ & $\begin{array}{l}\text { Development } \\
\text { stage }\end{array}$ & $\begin{array}{l}1 \\
2\end{array}$ & $\begin{array}{l}\text { Demonstration phase } \\
\text { Operational phase }\end{array}$ \\
\hline & & Demonstrated on & 0 & No \\
\hline & & waste & 1 & Yes \\
\hline & & $\begin{array}{l}\text { Commercial } \\
\text { availability }\end{array}$ & $\begin{array}{l}0 \\
1\end{array}$ & $\begin{array}{l}\text { Not commercially available } \\
\text { Commercially available }\end{array}$ \\
\hline & & 'lime: proven & $\begin{array}{l}0 \\
1\end{array}$ & $\begin{array}{l}\text { Not time proven } \\
\text { Time proven }\end{array}$ \\
\hline \multirow[t]{4}{*}{20} & Versality (VRSL) & Waste exclusion & $\begin{array}{l}1 \\
2\end{array}$ & $\begin{array}{l}\text { Some fraction of waste N/A } \\
\text { All waste acceptable }\end{array}$ \\
\hline & & $\begin{array}{l}\text { Pretreatment } \\
\text { requirements }\end{array}$ & $\begin{array}{l}0 \\
1\end{array}$ & $\begin{array}{l}\text { High } \\
\text { Low }\end{array}$ \\
\hline & & leed variability & $\begin{array}{l}0 \\
1\end{array}$ & $\begin{array}{l}\text { Presents a concern } \\
\text { No concern apparent }\end{array}$ \\
\hline & & $\begin{array}{l}\text { Upper temperature } \\
\text { range }\end{array}$ & $\begin{array}{l}0 \\
1\end{array}$ & $\begin{array}{l}\text { Relatively lower temperatures } \\
\text { Relatively higher temperatures }\end{array}$ \\
\hline \multirow[t]{4}{*}{30} & Residual solid prodict (RSP) & DRIi potential & $\begin{array}{l}1 \\
2\end{array}$ & $\begin{array}{l}\text { Low/unknown } \\
\text { High/demonstrated }\end{array}$ \\
\hline & & Chemistry control & $\begin{array}{l}0 \\
1\end{array}$ & $\begin{array}{l}\text { Tends to be difficult } \\
\text { Tends to be easy }\end{array}$ \\
\hline & & Favorable leach dala & $\begin{array}{l}0 \\
1\end{array}$ & $\begin{array}{l}\text { Doesn't exist } \\
\text { Lixists }\end{array}$ \\
\hline & & Volume reduction & $\begin{array}{l}0 \\
1\end{array}$ & $\begin{array}{l}\text { Low tendency } \\
\text { High tendency }\end{array}$ \\
\hline \multirow[t]{3}{*}{15} & Effluents (EFL'T) & Volume & $\begin{array}{l}1 \\
2\end{array}$ & $\begin{array}{l}\text { Iligh volumes } \\
\text { Low volumes }\end{array}$ \\
\hline & & Particulate & $\begin{array}{l}0 \\
1\end{array}$ & $\begin{array}{l}\text { High particulate generation } \\
\text { Low particulate generation }\end{array}$ \\
\hline & & Other considerations & $\begin{array}{l}0 \\
1 \\
2\end{array}$ & $\begin{array}{l}\text { Extensive offgas considerations } \\
\text { Moderate offgas considerations } \\
\text { Few offgas considerations }\end{array}$ \\
\hline \multirow[t]{4}{*}{20} & $\begin{array}{l}\text { Operational considerations (OPS) } \\
\text { (Divide score by } 2 \text { ) }\end{array}$ & Complexity & $\begin{array}{l}1 \\
2 \\
3\end{array}$ & $\begin{array}{l}\text { Highly complex process } \\
\text { Moderately complex process } \\
\text { Simple process }\end{array}$ \\
\hline & & Healthlsafely & $\begin{array}{l}1 \\
2 \\
3\end{array}$ & $\begin{array}{l}\text { Extensive considerations } \\
\text { Moderate considerations } \\
\text { lew considerations }\end{array}$ \\
\hline & & Maintenance & $\begin{array}{l}0 \\
1 \\
2\end{array}$ & $\begin{array}{l}\text { High maintenance reqs. } \\
\text { Moderate maintenance reqs. } \\
\text { Low maintenance reqs. }\end{array}$ \\
\hline & & Throughput & $\begin{array}{l}0 \\
1 \\
2\end{array}$ & $\begin{array}{l}\text { Low potential } \\
\text { Moderate polential } \\
\text { lligh potential }\end{array}$ \\
\hline 5 & Cost & Capital & $\begin{array}{l}1 \\
3 \\
5\end{array}$ & $\begin{array}{l}\text { High } \\
\text { Moderate } \\
\text { low }\end{array}$ \\
\hline
\end{tabular}




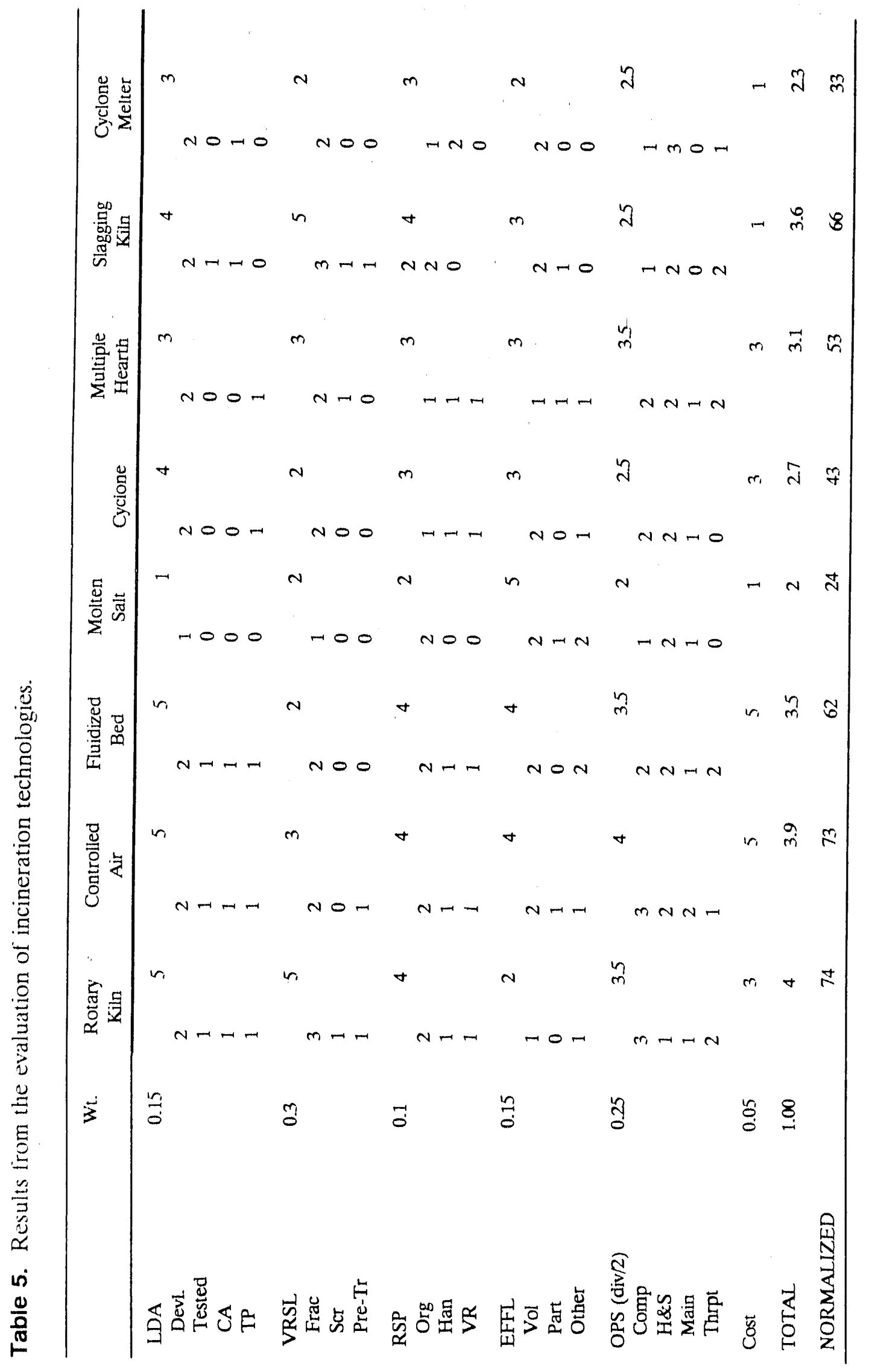


contaminated soils, sludges, and bulk combustible and inert materials. There are some drawbacks, however. Rotary kilns rate low in the area of effluent control, sinee they are high air-volume, high-particulate processes. Operationally, they are somewhat less desirable, mostly due to concerns with the rotating vessel and the special seals that are required. New seal designs are being developed to help minimize these concerns.

The controlled air incincrator addresses some of the concerns of the rotary kiln. Controlled air incinerators are designed specifically for the ability to use low air volumes and velocities in the primary chamber and, thus, are low-particulate generators. Controlled air incinerators rate well in the area of eflluent control and are the most predominant technology in use presently for radioactive waste processing. Their primary drawback is in the area of versatility and feed preparation. For a combustible waste feed of strictly bulk organic material, the controlled air incinerator is superior. However, little is known about their ability to process soils and sludges, as other incinerators are usually chosen for those types of applications. It should be technically feasible to process soils and sludges in a controlled air incinerator, particularly because of the more versatile ash handling designs that are now available. Because of the advantages in offgas concerns, process simplicity, and overall performance of the technology, the ability to aceept a more variable feed should be investigated more closely.

The slagging kiln rates somewhat lower than the rotary kiln and controlled air, but still rates relatively well. In fact, many of the advantages of the rotary kiln are obviously applicable to the slagging kiln as well, such as the versatility of feed aceeptance. The one additional advantage the slagging kiln has is that the solid residual it produces is a vitrified product. It is not likely that the slagging kiln will produce the quality of product that will be required for ultimate disposal (see the melter discussion below); but, there may be an intermediate handling advantage to be gained in providing a more stable feed material for a subsequent melter process. It needs to be determined whether this factor is significant enough to outweigh the additional operational concerns that use of this technology could bring about.

The lluidized bed is down-rated primarily based on its lack of versatility for the aceeptance of leed material. However, fluidized bed incinerators have some characteristics that may warrant further evaluation as a technology for this application. The high silica content of the INEL soil means that it should make an excellent fluid bed material. The thermal efficiency of the process and its turbulent mixing and abrading action will provide very high carbon burnout and promote homogeneity of the product, benefiting feed to the melter process. The residual product is a dispersible ash; however, the nature of the material, having been abraded to a fine, fluidizable state, will open the possibility of transport to the next proeess step via totally sealed, double walled, pneumatic transport systems, providing excellent containment. Unlike the rotary kiln and controlled air incinerators, which depend on maintaining a negative pressure inside the primary chamber to prevent out-leakage at seals, the fluidized bed process vessel is designed as a positive pressure-sealed deviee. The fludized bed may then be less susceptible to leakage due to positive pressure excursions caused by nonuniform rates of combustible feedstocks. Finally, the process thermal efliciency provides for operation at lower temperatures, minimizing NOx formation and melal volatilization. This, logether with the in-bed scrubbing of $\mathrm{HCl}$ and the reduced air 
volumes required, lead to some significant advantages in effluent control. Thus, the fluidized bed technology should be considered, focusing on methods and developments for overcoming feed versatility drawbacks.

The multiple hearth technology is not rated as a high contender for application, and appears to present no real advantages. The staged design of the multiple hearth technologies is most effective for drying large quantities of high moisture materials, such as the sewage sludges they were originally designed to treat. Its versatility is also somewhat limited by its feed requirements. The complex moving components of the rabble arm system will require frequent maintenance. The technology has never been applied for incinerating high heating value materials. Probably the most telling fact concerning the multiple hearth is that it is no longer being put into service, but is instead being replaced by other more versatile technologies. The multiple hearth should not be considered for application at the RWMC.

The cyclone melter and cyclone incinerator technologies rate moderately in most of the attributes, offering no real advantage in any category. The only real plus for the cyclone melter in this application is that it can, depending upon slagging temperature, produce a residual solid product that is partially vitrified, and thus easier to handle. However, this is not believed significant enough at this point to make up for the other disadvantages. The most restrictive problem is that the feed material pretreatment requirements will be restrictively high. In fact, it is questionable whether the bulk combustible components can be adequately prepared for feed, sinee the feed has to be size reduced to a material that is fluidizable by a gas stream. Certainly, tramp metals are a problem. These technologies are designed for use in treating gasses, liquids, and small particle size homogeneous solid streams, and thus are not readily applicable for the wide range of bulk heterogeneous solid materials they would have to process at the RWMC. A further more detailed evaluation of the cyclone melter is provided in Reference 3.

The molten salt furnace system is rated as the lowest overall incinerator/oxidation technology. While the molten salt process excelled in the gaseous effluent evaluation, there are a number of other concerns that cause its low rating. The molten salt technology is a relatively new technology in the waste treatment area, and little is known about its long-term effectiveness as a waste processing technology on an operational scale. The molten salt process also rated low in versatility, having significant waste pretreatment and screening requirements, and limited applicability for the waste being considered. Molten salt technology is being developed for combustible materials processing and does not handle high volumes of inerts well. Overall, the molten salt process does not appear to be an effertive technology for buried waste treatment. Further more detailed evaluation of the molten salt process is provided in Reference 3.

\subsection{Ranking of Melter Technologies}

The results of the evaluation of melters is presented in Table 6. The electro-technologies are more desirable than the fossil-fueled technologics for radioactive waste processing for several 


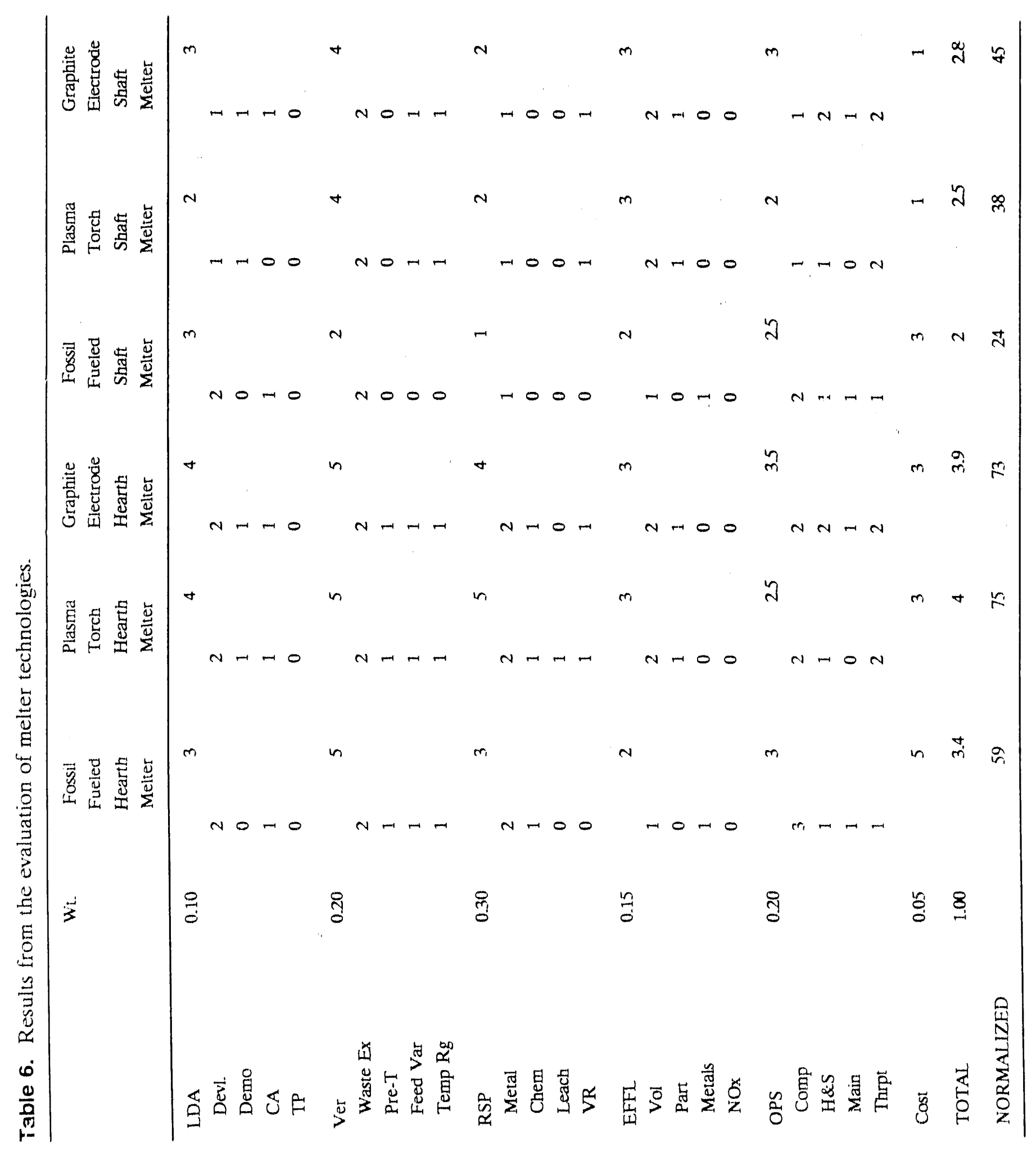




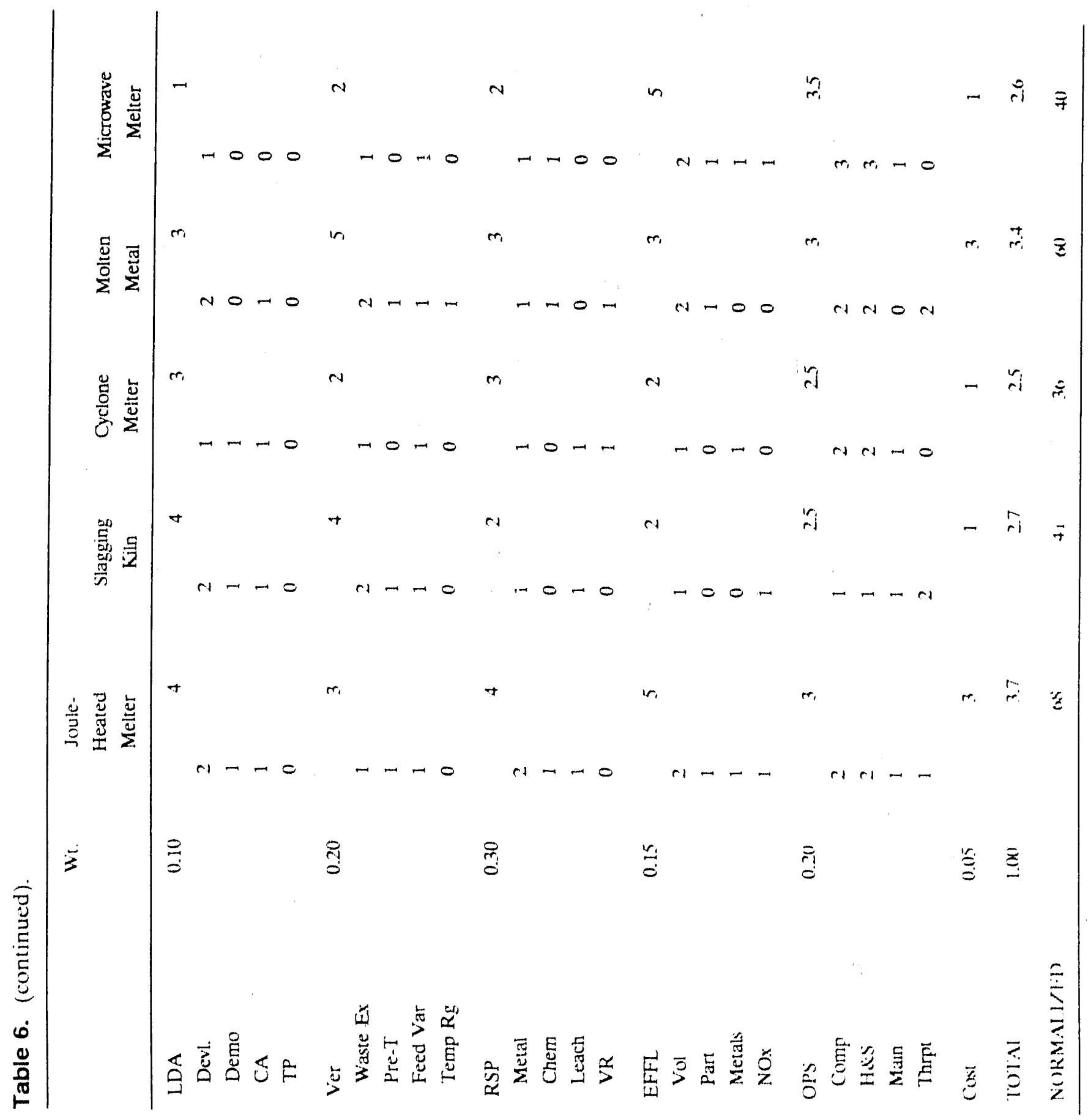


reasons. The small volume of offgas expected from processing inert waste is desirable. Using a fossil-fueled technology to provide process heat to the inert waste will generate a much larger volume of offgas than would otherwise have to be handled and treated. Based on this larger offigas volume and velocity, particulate entrainment and carryover can be expected to be much higher as well. Process equipment will also have to be sized much larger for given throughput. In addition, fossil-fueled technologies rely upon combustion to create heat and, therefore, are limited to the combustion flame temperature as the upper temperature they can attain. Fluxing agents must be used to lower melting temperatures and slag visesity characteristics. Oxygen enrichment could help obtain higher temperatures, but this creates additional operational complexity and additional cost.

Three of the technologies appear to be superior in the most important attributes, thus causing these technologies to achicve the highest overall ratings. These are the hearth configured electrotechnologies, both plasma torch and graphite electrode are melters, and the joule-heated melter technology.

There is little difference in the evaluation of the plasma/are heated hearth technologies, which is expected based on their similarities in concept, design, and operation. The only apparent differences are in the slightly higher desirability of the graphite electrode process from an operational reliability/availability standpoint, offset by its apparent lack of leachability data from testing. The former relates to the degree of frequency of maintenance required to replace electrodes in the plasma torch (every 100 to 200 hours of operation) and the operational concerns involving the potential release of the torch coolant into the molten bath. As for the latter, there appears to be a lack of reported leaching data to confirm the potential characteristics of the slag product from the graphite system. However, it is anticipated that leachability characteristics of the product should prove to be as favorable as those of the product from the plasma torch system. When demonstrated, this will increase the rating for the graphite electrode system. For the most part, at the level of detail of this study, there is little discernable differenee between the plasma torch and the graphite electrode hearth melter systems.

The third technology identified as having the highest potential for addressing the needs of a melter process for the RWMC inert waste is the joule-heated melter (JHM) process. This technology is probably the most mature melter technology with respect to radioactive waste processing, having been developed extensively as part of the high-level waste program. In addition, the effluent control inherent in the JHM process (minimal offgas, low particulate, and lower metals volatilization and NOx formation potential due to lower operating temperature) adds to the positive rating. The demonstrated ability of the system to produce a desirable end product is a plus.

On the downside, the relatively lower temperature capability of the existing JHM process detracts from its versatility. Higher melting point materials will present problems. For example, tramp metals are not readily processed in the melter, and are actually best left excluded from the feed. The lower temperature also requires the addition of a significant quantity of fluxing agents to 
reduce the melt temperature when a high quantity of silica and alumina is present, as is the case for the INEL soil. This will hamper the ability to control the process chemistry, and will significantly add to the overall final disposal volume. Finally, the lower operating temperature leads to redued throughput potential, as the rate of heat transfer to the feed material largely determines throughput potential. Currently planned developments will focus on some of these drawbacks.

The molten metal bath technology, which relies upon a molten metal pool to effect processing, represents a variation of the discussed hearth technologies, which intend to operate with slag as the molten pool rather than metal. Thus, many of the same advantages of these systems also apply to a molten metal process. The molten metal pool may have an advantage in providing a reservoir for tramp metals in the feed material and may provide a very effective system for transfer of heat to the feed materials. The potential for an accidental feed of noncombustible liquids, particularly water, below the molten surface raises the concern of a vapor explosion; the possibility for such an oceurrence, although small, would have to be evaluated. There appears to be a lack of reported leaching data to confirm the potential characteristics of the slag product from the molten metal system. However, it is anticipated that leachability characteristics should prove to be similarly favorable to those of the plasma torch system. In general, little information is available to provide a sufficient evaluation of this option, and perhaps some further study may be warranted.

Of the electro-technologies, the shaft (or cupola) configuration technologies rate low, with not a great deal of variation between the plasma torch or graphite electrode heated systems. One reason for their low rating is that their stage of development in waste treatment applications is not as advanced as other technologies. In addition, shaft based configuration melter technologies have proven to have some greater operational concerns than the other processes related to the difficulties in maintaining proper waste densities in the column, the potential for the offgas to "channel" as it progresses through the waste feed, and the inherent potential for the waste matcrial to "bridge" in the furnace. All of these create highly undesirable situations.

Most important, however, is that control of the residual solid product from the shaft melters is very difficult. The product is only controllable based on what is fed at the beginning of the travel of the waste down the shaft, which entails an approximation of the expected chemistry upon its entry into the process zone. The short residence time of the material in the process zone inhibits achieving homogeneity of the slag product. There is also little control of the fate of bulk metals in the feed matcrial. Since the production of an optimum residual product, which is the primary function of the melter process, is the most important consideration in this evaluation, this significantly affects the shaft furnace rating.

The slagging incinerator technologies, slagging kiln and cyclone melter, are also rated low when considered as melter technologies. The fact that they are fossil-fueled technologies leads to increased offgas system concerns, as discussed previously. The slagging ability of each process is limited to lower temperature melting by maximum flame temperatures and heat transfer efficiency. This also requires significant quantities of fluxing materials to achieve a molten product, thus limiting versatility 
and increasing waste volumes. In addition, slag chemistry is more difficult to control, again based on up-front estimation of the waste characteristics, prefeeding of estimated quantities of chemistry control material, and, particularly in the case of the cyclone melter, very short residence times to effect waste mixing and homogencity. In addition, feed pretreatment sizing requirements $(<1 / 4 \mathrm{in}$. dia) are further limiting in the case of the cyclone melter.

The microwave melter technology is also not rated readily applicable for the application being considered. The technology rated well in the areas of effluent control and operational considerations, based on the ability to totally enclose the process in a glovebox and control that environment. However, the technology is determined to be relatively inferior in several of the key evaluation ranking attributes. It is a relatively new process and little is yet determined about its long-term performance. It is not a versatile technology, having been designed specifically for treatment of sludges. Temperatures achievable are limited, which further limits versatility. Even more important, the residual product that results from the technology is inferior relative to the product from the other technologies. There is little driving force to promote mixing and homogeneity, leading to variability in the product. In fact, some data show that the process produces stratified layers having differing physical characterisitcs. Finally, there is no available data on the control of leachable metals from the residual product.

Further more detailed evaluation studies related to the plasma torch, arc melter, and joule heated melter technologies are in progress and will be reported in Reference 4. More detailed evaluations of the microwave melter, molten metal melter, and fuel fired torch melter are provided in Reference 3. 


\section{CONCLUSIONS}

A leading strategy for the remediation of the buried TRU waste at the RWMC is to retrieve the material and effect some form of segregation of the waste components to optimize treatment. A particularly attractive treatment strategy is to use an incinerator to process the hazardous and bulk organic fraction of the waste, and to use a melter process 10 provide the high quality final waste form that is required for noncombustible mixed TRU residuals. Both technologies have been designed for these specific purposes and should perform effectively with a high probability of success in these applications.

Melting technologies can' be operated such that they oxidize an organic waste fraction; however, incinerators have been designed and developed specifically for this purpose, and will function much more effectively than a melter in this regard. There are also other benefits to preprocessing organics in an incineration step and processing the residual inorganics in the melter process to achieve the final waste form. Such a strategy will maintain a minimum offigas volume from the melter process, thus allowing melter afterburners and offgas trains to be small and compact systems. This creates advantages in equipment and facility design, process complexity and controllability, and perhaps even in pereeption. These advantages disappear rapidly with increasing organic loading in the waste, as offgas system design will then be driven by the offgas products from the processing of the organics. In addition, elimination of organics allows a greater flexibility of operation of the melter process to control chemistry.

In general, incineration technologies have been well developed over the last two decades and are well understood technologies for the application being considered at the RWMC. Many incineration technologies have been construcled and are now operating in hazardous waste service throughout the U.S., and many are in use for remediating hazardous waste sites. Clearly, incineration is a remediation strategy that should be seriously considered as an alternative for the RWMC project. Several technologies, including the rotary kiln, controlled air, slagging kiln, and fluidized bed, are acceptable potential candidates for processing the materials being considered. The available data on these technologies should be evaluated in greater detail to determine which lechnology will provide the best alternative for application in the RWMC remediation project.

Of the melter technologies, the electrically-powered processes are the most desirable. Of these, the processes that appear to have the highest potential for sucesssul application are the graphite electrode plasma are technology, the plasma torch technology, and the joule-heated melter. Each of these technologies has a high potential to aceept a wide range of waste materials and process them into a residual vitrified solid product that will meet or exeed the stringent requirements for product quality, integrity, and control of leachability. Near-term efforts should focus on demonstrating the capabilities to ensure they will function as intended, and developing these lechnologies as necessary so they can be fully adaptable for treatment of TRU containing material. 


\section{REFERENCES}

1. J. L. Mayberry, F. Feizollahi, J. C. Del Signore, and W. J. Quapp, "Preliminary Systems Design Study Assessment Report," EGG-WTD-9594, July 1991.

2. "Thermal Processes Evaluation for RWMC Wastes," EGG-WTD-9449, January 1991.

3. J. Batdorf, R. Gillans, G. Anderson, "Selected Furnace Technology Assessments for RWMC Wastes," EGG-WTD-10036, February 1992.

4. A. Donaldson, R. Carpenedo, and G. Anderson, "Melter Development Needs Assessment for RWMC Buried Waste," EGG-WTD-9911, Fcbruary 1992. 


\section{BIBLIOGRAPHY}

"Arc Pyrolysis Technolngy," Electropyrolysis Inc., Waync, PA, 1990.

Armstrong, Katherine M. ct al., "Joule-Heated Glass Furnace System for the Incineration of Low-Level Radioactive Wastes," Monsanto Research Corp., Mound Laboratory, Report No. MLM-3018, 1987.

"Ausmelt Designers and Suppliers of Sinosmelt Smelters" Corporate brochure, Ausmclt Pty. Ltd., P. O. Box 1003, Dandenong, Victoria, 3175 Australia, 1990.

Babcock \& Wilcox, "Cyclone Furnace for Waste and Treatnent of Contaminated Soil Phase I," Final Report, U.S. Environmental Protection Agency Risk Reduction Engineering Laboratory, March 1991.

Benedict, R. W., and F. R. Weitz, "Thermal Oxidation of Hazardous Waste in a Fluidized Bed Combustor," Waste Tech Services Inc.

Breton, Mare et al., "Technical Resourec Document: Treatment Technologies for Solvent Containing Wastes," U.S. Environmental Protection Agency, EPA/60()/2-86/095, October 1986.

Brunner, C. R., "Incineration Systems-Selection and Design," Incincrator Consultants Incorporated, Reston, VA, 1988.

Buelt, James L., Contact, Battelle, Pacific Northwest Laboratory, P.O. Box 999, Richland, WA 99352, (509) 375.2927.

Camacho, S. L., "The F1 Manual: Application of Plasma Technology," Plasma Energy Corp., Raleigh, N. C., 1988.

Camacho, S. L., "Industrial-Worthy Plasma Torches: State-of-the-Art," Pure and Applied Chemistry, Vol. 60, No. 5, 1988, pp. 619-632.

Camacho, S. L., "Plasma Heating," Handbook of Applied Thermal Systems, McGraw-Hill, 1988.

Cotchen, J. K. and H. F. Davis, "A Successful Slag Vitrification Arc Furnace," Electric Furnace Procecdings, Vol. 48, New Orleans, 1990.

Cudahy, J. and T. Eicher, "Hazardous Waste Incineration Course," IT Corp., August 1988. 
Dighe, S. V., "Westinghouse Plasma-Fired Processes for Treatment of Industrial Wastes,"

Westinghouse Electric Corporation, Madison, PA, published in Iron \& Steel Engineer, January 1992.

Draper, A. B., R. E. Keith, and J. Gerin Sylvia, "The Cupola Furnace: State-of-the-Art," Department of Industrial and Management Systems Engineering and Center for Air Environment Studies, Pennsylvania State University, $199($ ).

Eschenbach, R. C., R. A. Hill, and J. W. Sears, "Process Description and Initial Test Results with the Plasma Centrifugal Reactor," Forum on Innovative Hazardous Waste Treatment Technologies, Atlanta, GA, June 19-22, 1989.

Falcone, P. W. and R. J. Buchanan, "Hazardous Waste Incineration by Slagging - Mode Rotary Kiln," 20th Annual Mid-Atlantic Industrial Waste Conference, Washington, D. C., June 1988.

"The Feasibility of Incinerating and Vitrifying Organic Resins in a Single Step," The Handling and Treatment of Radioactive Wastes, edited by A. G. Blasewitz et al., James L. Buelt, Pacific Northwest Laboratory, 1984.

Frankel, J., N. Sanders, and G. Vogel, "Profile of the Hazardous Waste Incincrator Industry," MITRE Corp., 1982.

Freeman, H. M., "Innovative Thermal Hazardous Waste Treatment Processes," PB85-192847, April 1985.

Frecman, Harry, Innovative Thermal Hazardous Organic Waste Treatment, Noyes Publications, Park Ridge, NJ, 1985.

Frecman, H. M. et al., "Thermal Destruction of Hazardous Waste - A Statc-of-the-Art Review," Journal of Hazardous Materials, Vol. 14 (1987), pp. 103-117.

Fruchan, R. J., "Plasma Processes for Metals Production - A Scoping Study," The Center for Metals Production, October 1985.

Gay, R. L. et al., "Destruction of Toxic Wastes Using Molten Salts," Technical Meeting of the American Institute of Chemical Engineers, Anaheim, CA, April 1981.

Goodwill, J. E., "Proceedings of the First International EPRF Plasma Symposium," CMP Report No, 90-9, May 1990, Chapters 11, 13, 14, and 16. 
Goodwill, J. E., Procedings of the First International EPRI Plasma Symposium, The EPRI Center for Matcrials Production, May 199().

Hnat, J. G., W. F. Olix, W. F. Talley, and L. M. Bartone, "A Cyclone Melting System for Processing Hazardous Waste Dusts," Vortec Corporation, Collegeville, PA, February 1991.

International Union for Electroheal, "Arc Plasma Processes; A Maturing Technology in Industry," UIE Arc Plasma Review, 1988.

Johanson, J. G. et al., "Destruction of Hazardous Wastes by the Molten Salt Destruction Process," Seminar of the American Society of Testing Materials Committee D-27, Nashville, TN, March 1982.

Klingler, Larry M. and Perry L. Abellera, "Joule-Heated Glass Furnace Processing of a Highly Aqueous Hazardous Waste Stream," EG\&G Mound Applied Technologies, ML.M-3577. March 1989.

Koenig, R. A., J. McFec, and J. S. Vauruska, "Incincration Systems," Incincration Conference 1990), San Diego, CA, May 1990.

Komatsu, F., et al., "Application of Microwave Treatment Technology to Radioactive Waste," Proceedings of the 1989 Incincration Conference, Knowille, TN.

Kujawa, S. T., "Plasma Arc Furnace Experiments HAZWRAP 1989 Annual Report," MSE Inc., Butle, MT, January 1990.

Lee, C. C., G. L. Huffman, and D. A. Oberacker, "An Overview of Hazardous/loxic Waste Incincration," Hazardous Waste Mamagement, Vol. 36, No. 8, August 1986, pp. 922-931.

Lewis, A. C., "Beyond Incineration and Landfills Photo-Electrokinetic Process for the Disposal of" Solid and Semi-Solid Waste," Scorpion Mining \& Manufacturing Company, Libby, MT, 1991.

MeCormick, R. J., et al., Costs for llazardous Waste Incineration, Noyes Publications, Park Ridge, N.J, 1985.

Medres, C. W., "Waste-to-Energy '87: Exploring the Total Market," Badger Engineers, Inc., 1987.

Penberthy Electromelt International, Inc, 6.31 South 96th Strect, Scattle, WA, 98108, "A Company" Description," February 1988. 
Penberthy, Larry, "Two Pathways to Action in Dealing with Sccondary Materials," Conference on the Leading Edge of Incineration and Thermal Destruction of Hazardous Wastes, Washington, DC, September 1987.

Petersen, R. D. et al., "Application of Microwave Energy for Solidification of TRU Waste," American Nuclear Society 1987 Winter Meeting, Los Angeles, CA, November 1987.

Petersen, R. D. "Microwave Vitrification of Rocky Flats TRU Sludge," American Nuclear Society 1989 Winter Meeting, San Francisco, CA, November 1989.

Peterson, Robert D., Contact, EG\&G Rocky Flats, Rocky Flats Plant, Denver, CO, (303) 966-4051.

Rath, G., T. Vlajcic, and O. Metelmann, "Lead Smclting in a Submerged Arc Furnace," Journal of Metals, June 1990.

Rich, G., and K. Cherry, Hazardous Waste Treatment Technologies, Pudvan Publishing Co., 1987.

Rich, G., and K. Cherry, Hazardous Waste Treatment Technologies, Pudvan Publishing Co., Northbrook, IL, 1987.

Rich, Gerald and Kenneth Cherry, Hazardous Waste Treatment Technologies, Pudvan Publishing Co., 1987.

Smith, Jeffrey D., "Molten Metal Technology," EI Digest, July 1991, pp. 8-13.

Sweet, W. E., R. D. Ross, and G. V. Velde, "Hazardous Waste Incineration: A Progress Report," Journal of the Air Pollution Control Association, Vol. 35, No. 2, February 1985.

"Technical Resource Document: Treatment Technologies for Solvent Containing Wastes," U.S. EPA, EPA/60)/2-86/095, October 1986.

"Thermal Destruction of Hazardous Waste - A State-of-the-Art Review," Journal of Hazardous Materials, Vol. 14, 1987, pp. 103-117, Elsevier Science Publishers B.V., Amsterdam, Netherlands.

Tillman, D. A. et al., "Rotary Incineration Systems for Solid Hazardous Wastes," Chemical Engineering Progress, July 1990.

Van de Voarde N. el al., "High Temperature Incincration of Radioactive Waste," Nuclear Science and Technology, Commission of the European Communities, 1986. 
Van de Voarde, N. et al., "High Temperature Slagging Incincration-Recent Operating Experience," Spectrum '86, American Naclear Society International Topic Meeting, Niagara Falls, NY, 1986.

Wshima, Hirofumi et al., "Continuous Penctration Test Equipment Using Microwave Heating," RFP-TRANS-462, Translated from Toshiba Revicw, 39(7), 1984, pp. 611-614.

Yates, Ian C. and J. E. Johnston, "Resource Recovery with Catalytic Extraction Processing," Environmental Waste Management, May 1991, pp. 30)-31. 


\section{Appendix A}

Basis for the Determination of Waste Stream Components 


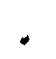

.

A. 2 


\section{Appendlx A}

\section{Basis for the Determination of Waste Stream Components}

The purpose of this study is to evaluale the anticipated performance of alternative thermal treatment technologies for the situation where the RWMC waste is segregated into a primarily combustible fraction and an inert fraction. It is necessary to deline basic physical and chemical properties of the feed material for both eategories. From the evaluation of existing data available on the RWMC waste characteristics, the following waste calcgories have been established.

\section{Combustible Waste}

T'he RWMC combustible waste is primarily composed of items that were generated in the daily operations of the RFP and the INEL. The most prevalent constituents in the buried waste are paper (c.g., blotting paper, computer paper), wood (c.g., lilter frames, building debris), cardboard (e.g., boxes, containers), plasties (e.g., polyethylene bags and boltles, PVC shoe covers), and rubber (e.g., latex gloves, rubber mats). Due to the nature of operations in a radioactive environment, plastic and rubber will comprise a larger perecntage of the combustible materials than would normally be expected from an industrial type of an operation. The combustible waste fraction will therefore have a higher heating value than would normally be expected.

\section{Sludge Waste}

Sludge wastes were also disposed of in the RWMC in significant quantity, and represent perhaps as much as $10 \%$ of the overall disposal volume. The vast majority of the sludge waste disposed was from the Rocky Flats Plant (RFP). RFP sludges consisted of five basic types of sludge. A general description of each sludge type along with an estimale of its quantity is presented in Table 1.

The current physical state of the disposed sludges is not known at this time. Their state will likely depend to a large extent on the condition of the disposal container that the material was disposed in, and, for breached eontainers, if it was chemically altered in any way by its surroundings. Originally, several of the sludges eontained a large quantity of water by weight; however, sinee the sludges disposed were the product of a filtration dewatering process, this water is not likely to be free licyuid, but rather water of hydration lor the sludge. 


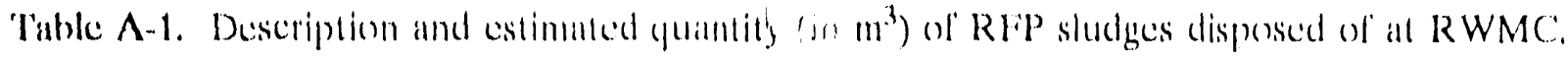

Series 741 siludge

Series 742 sludyo

Series 743 sludge

Serles 744 sludge

Series 745 sludge
Flrst stage sluelge: Obtalned from treating aqueous process waste; preclpliate of hydrated oxides of Iron, magresilum, alumiman, silicon, plutonlum, ard anericlua is filtered to produce oludoe that is 50 to $70 x$ water by weight.

Second stage sludge: proctuced from the treatment of all other plant radloactive and/or chemical coritaminated wastes and further treatment of 741 Sludge; may also contsin nercury and lithlum batieries and small amounits of contuminated mercury In pint bottles; flltered to proctuce. sludge 50 to $70 x$ water by Helutit.

Organle set-Ups : produced from treatment of llquid organlc wastes; organle wastes vere inixed with calcium slllcate to form a paste-like material; consists mainly of trichloroetharie, iexaco Regal oll, and carbon tetrachlorlde, hrdraulle olls; other organles include trichloroethylene, cetrachloroethylene, gearbax and spirdle olls; also some unkrown volune of oils containing PCB's.

Special set-Ups: Resulted from processing liquid wasto not compatible with the 741 and 742 processes because of their plutonlun complexing nature Includes alcohols, orgonlc acids, EDTA. Solldifled with Portland cerment

Evaporation salts : orlginated from evaporation of liquid waste lmpounded In solar evaporation pords: est imated to coritain 60X sodiun nitrate, $30 x$ potassiua nitrate, and $10 x$ miscellareous matertal.
1983.87

3280,33

2014.95

338.78

1831.32

\section{Brickiconcrele}

Brick, concrete, and other similar construction malerials represent a significant portion of the RWMC waste. These materials, obviously non-combustible in nature, will be retrieved, size reduced as neceled, and are assumed to be processed in the melter system to produce their final waste form.

\section{Ciliss Wiske}

There is a relatively small percentage of the RWMC waste that is comsidered to be glass. (ilass waste was often managed as a separale category ol waste and was packaged separately for dispessal. Glass waste was generated primerily liom laboratory operations, and is assumed on be processed in the meller process.

\section{Drummed Bulk Melal Waste and I arge Bulk Motal ()bjects}

A large enmpenent of the RWMC waste is bulk metal waste. Aluch of this waste wats sired such that it was placed inte drums for shigment te the RWMC. Such bulk metal wiste will consist 
of primarily stecks (carbon, stainkess, cast); however, some aluminum, copper, and other melals will be present. Other bulk melals were dispesed of in their original form, and are very large. These will be almost exclusively stects, and comsist of such items as gloveboxes, vesseds, lathes and other large tools. Such items will present a special problem in their retriceval and processing.

For the purpose of this study, it is assumed that, in general, these drummed bulk melals will be trealed in a separate metals decontamination process, and not in the thermal processes being considered here. Therefore, large quantitics ol bulk metal are not addressed in this study. However, there will undoubtedly be smaller sized pieces of bulk metal objects that will be present within the waste malrix that will not be readily segregated out for separate processing. Thus, some quantity of tramp metals will be considered as a likely component in each of the two waste streams.

$\underline{\text { Soil }}$

Retrieval of the buricel waste will produce a very large quantity of peripheral soil that will potentially be contaminated with radionuclides and hazardsus materials. For the segregation scenario being evaluated, it is assumed that the bulk of the soil can be separated from the waste materials for separate handling. The actual volume of soil that will need to be treated will likely be reduced through either characterization and reclassilication of the soil as clean or low-level waste, or through treatment in a unit eperation referred to as soil washing. (Mayberry, 1991) Soil washing a process that is pestulated to concentrale radionuclides and hazardous materials into a smaller volume of soil that will then be treated thus minimizing treatment and disposal volume. The larger fraction of washed soil can be reclassified as clean or low-level, and handled without need of thermal treatment. This soil may serve as glass forming material to the melter process if desirable. The remaining smaller fraction of soil will have on be processed through either the melter or the incinerator as discussed below.

\section{Delermination of the Combustible Waste Composition for Incincralors}

This combustible waste compenent, containing primarily paper, plastic, cloth, oil, and other highly combustible materials, is certainly applicable for treatment in an incincrator. This type of material has been and continues 10 be incinerated on a regular basis. For example, this type of malerial has been processed in the WERF incinerator to a large degree of sucesess since 1985. (Ref WERF report).

Many commercial incinerators are eperaled using sludge wastes as a watste feed material. There appears to be advantages to processing cach of the RFP sludges in an incineration process prior 10 leced to a melter. Treatment requirements for the silicale-stabilied sludge will he mostly driven by the hazaldous organic solvents it contains (e.g. carbon cetrachloride) and thus the requirement for proper destruction and removal elliciency (DRL). Incinerallors are often designed and operated specifically (o) achice this ohjective. This sludge may present a potentially difficult. siluation in that it has been stabiliaed inten a paste-like" materiat in stect drums prior to ditipessal. 
Retrieving this material from the drums for treatment in an incinerator may prove to be a formidable lask. It is possible that the sludge drums could be fed whole to the process chamber; however, this is probably not the best solution. Feeding whole drums of volatile organic material may lead to excessive release of velatiles, calusing a process upset that may lead to the release of products of incomplete combustion. It may be possible to use an organic solvent, such as diesel oil, to slurry the sludge material such that it can be removed from the eontainers and fed into the incinerator through a sludge lanee. Another possibility is to utilize the cryolfacture technique to produce a materiat that will be casier 10 shred and then treat. Since the ultimate method of handling the sludge is uncertain at this lime, it should be a consideration in evaluating the versatility of incincration processes.

Treatment of the nitrate sludge in an incinerator should be useful in thermally decomposing the sludge into sodium and potassium oxides and nitrogen oxides (NOx). The sodium and potassium oxides would remain in the incinerator as a solid ash product. The NOx lormed will be evolved as a gaseous product, and will be carried off with the olfgas. Generation of NOx in the incinerator will pose a concern from the standpoint of offgas control, and will have to be dealt with through proper olïgas system design; however, this should not represent a particularly diflicult situation.

The inorganic aqueous sludges woukd benefit from being fed to the incinerator as an initial dewatering step prior to feeding to a melter process. These sludges contain 60 - 70 \% water, principally in the hydrated form. An incinerator is probably a belter process for diving off this water than a melter process. For one thing, the offgas system will be better designed for large quantities of volatile product. In addition, if the hydrated sludge is fed into a molten melal pool, a steam explosion is possible. The incineration process should also prove to homogenize the feed to the melter process for smoother feeding operation. The other slightly organic, solidified sludge should also benefit from destruction of some of the organie material eontained; however, this malterial will likely hate to be crushed prior to leeding.

The final feed component to be considered for the incineration process will be that portion of soil matrix that is heavily contaminated with organic solvents or other organic liquids. It maly be much more beneficial to process soils containing high volatiles in an incincrator rather than a melter, due to the relative proportion of offgeas expected from each process. One reason is that the organics contained in the soils will largely be hazardous solvents, and proper destruction efficiency will be required. Incinerators have been used many times in the past for treatment ol organic contaminated soiis, and have beer widely accepted ats a proper means of treatment. That is not to saly other technologics, such as melters, cannot process this waste, rather that regulatory pressure may kad lo the use of previously proven and aceepted methods. Secondly, large quantities of volatiles relcase will be much more readily handled in the incinerator, as the sceondary combustion chamber and offgas system will be beller sized for this type of siluation. The sceondary combustion chamber (if even needed) and offigas system from the melter system will be much smaller in capacity, and maly not adapl well to the sudden and extreme fluctuations that would be experienced in leeding highly velatile components for processing. It will be assumed for purposes of this study that $25 \%$ of the soil 
that is destined for treatment will be highly contaminated with organics, with the rest destined for direct feed to the melter process.

The last item that will be eonsidered as being present in combustible waste is tramp metals. As discussed previously, it is assumed that metals are to be segregated from the waste for separate handling in the metals processing system. However, some amount of tramp metal will likely pass through the screening into the combustible waste matrix. It will be noted if this presents a problem for any of the incineration processes.

\section{Determination of Non-Combustible (Inert) Waste Matrix for Melters}

For the purposes of this evaluation, the inert waste stream will be considered to consist of, the residual ash from the incinerator process, the RFP sludges, the soil fraction that was not sent to the incinerator, the brick and concrete waste, and the glass waste.

The residual from the incinerator will be fed to the melter process to produce the final disposable waste form. The inert residual from the combustible trash portion of the combustible waste will be approximately $5 \%$ of its feed mass. It can be assumed that the organic sludge will consist of approximately $50 \%$ of its original weight in ash. The soil will essentially pass through the incinerator with little or no mass reduction. The incinerator residual composition will consist of a high concentration of silica and alumina compounds, residual tramp metal, and fixed carbon not burned out by the process.

It is possible that in...ne of the sludge waste types could be fed directly to the process rather than through the incineration process first. This evaluation will eonsider this as a possibility. The inorganic sludges are obvious candidates for the melter process, even though they have a high water content. Some of the sludge has been cement stabilized, and will have to be processed in some form of shredder or crusher prior to feed to the process. Those solidified drums when shredded will most likely kad to tramp metal (from the drum) that will not be able to be separated from the feed, and this will be considered in the evaluation.

The brick and concrete will be processed through the same shredder as the cemented sludges so that this waste form will be reduced in size for effective leceding to the process. This is very straight forward, and presents little apparent concern for any of the melter processes.

The glass waste will likely best be crushed to assure removal of containerized liquids prior to feed. The feeding of containerized liquid to a thermal process represents a situation where the container and its contents will heat up to the point that, when the container breeches, the liquid will be volatilized rapidly. Such a situation presents operational control difliculties, and should be avoided. Any liquid collected from the glass crushing operation will be prepared for feed to the incincrator process; however, this is assumed to represent a negligible quantity of waste. 
Appendix B

Evaluation Methodology

B! 
B-2 2 


\section{Appendix B}

\section{Evaluation Methodology}

In order to evaluate the different technologies within each of their eategories, a standard set of evaluation criteria was delined. For the purpose of this study, the basic evaluation methedology advanced in EGG-WT'D-9449 was usod and modified for the specilic concerns of this study. That methodology involved the definition of a number of characteristics, or attributes, that are important in considering a particular thermal treatment process. Technologies are assessed on their performance with respect to these altributes, and a relative numerical seore is assigned. Individual attribute scores are assigned a weighing based on the relative importance of that attribute.

Specilic criteria are defined within each of the individual attribute categories. These criteria are used to determine a technology's rating with respect to its performance for that attribute. The criteria are established in such a way that a technology will receive a score between 1 and 5 for each attribute. The individual attribute ratings are then adjusted by a relative weighing factor, and are summed to arrive at an overall "score" for each technology. The total scores are then normalized to a scale of 0 to $1(0)$ to provide better comparison of results. These normalized overall seores can then be compared among the similar technologies to provide a ranking of the technologies most likely to meet the requirements for processing $\mathrm{RWMC}$ wastes.

The general attribute categories remain the same for evaluating both the incinerators and the melters. However, some of the attributes have slightly different suberiteria for the melter and incinerator evaluation based on the specifie requirements of the technology category. The relative attribute weighting factors assigned must also be slightly different between incinerators and melters, as each is intended to provide different functions and meet different requirements. Therefore, a separate criteria matrix was established for each of the two technology calegories to account lor these differences. These matrices are displayed in Tables 3 and 4 . The following section describes the general attributes and specilic criteria used in each technology evaluation.

\section{Definition of Attributes and Evaluation Criteria}

\section{Level of Development and Availability (LDA)}

This attribute was established to evaluate the maturity and availability of the various lechnologies. Strict timeframes are being negotiated for the remediation of the RWMC, and the peried for technology development is relatively short. Therefore, technologies that are fully developed, operational, time-proven, and commercially available should be given somewhat higher consideration than emerging, unproven technologies. 
The I.DA allribute is compesed of lour criteria. The criteria are the same for both the incinerater echnologies and the melter technologies. An important consideration is the stage of development of a technology. Operational technologies pesent more ectainty in their pertormance over developing technologies; and are, therefore, alforded a betler raling. Another eonsideration is whether or not the technology has been demonstrated on waste types similar to those being considered in this study, which would remove uncertainty of a particular technology's applicability to the RWMC waste. A particular technology witl rate somewhat better if it is commercially available, rather than designed and built on a one-time only basis; commercially available technologies provide higher certainly of their probability of sucecsstul operation. Finally, a lechnology that has been time.proven in waste processing service should be alforded a higher eonsideration than a relatively newer ecchnology.

\section{Versalility (VRSL)}

There are a number of lactors that make up versatility with respect to the waste leced properties. Even though in the postulated scenario, where the waste to be treated will be segregated by trealment category, it is likely that the efficiency of the segregation will be limited by technology and/or safely considerations. In addition, waste within a treatment calegory can be expected lo vary a great deal. Finally, there were some simplifying assumption made in the characterization of waste calegories addressed in an earlicer section of this report. It is likely that these simplifying assumptions will not prove to be completely true when more information becomes known, most likely upon the actual retrieval of the waste. Thus, for the purposes of this evaluation of technologies, it will be important to know where limitations may exist in a given technology's ability to aceept a range of input malcrials.

The eriteria delined for each technology type will be slightly different. For incinerators, there are three basic criteria. A cletermination is made of the fraction of materials that will be treatable for that particular eategrory. The need to sereen restricted items is judged for each technology, as the need for screening tends to increase operating costs and personnel exposure standpoint. Lastly, echnologies are rated on their need to have the waste shredded or otherwise pretreated prior to feed. Such pretreatment introduces an extra operation in the overall process that should be avoided if pessible. Shredders can be maintenanee problems, and also tend to introduce particulate into the: air.

In the case of melters, the fraction applicable and pretreatment criteriat are also applied for the same reasons as discussed for incineraters. Two additional criteria are added for the melters: feed variability concerns and a measure of the upper temperature range. Since the inert waste feed will likely vary a greal deat, it is important to know what ellece this may have in the melter process. The upper temperature range is important in that technologies that can achieve higher temperatures will provide more versatility in handling a wide range of materials, particularly some of the higher melting temperature compounds that are anticipated in the inert waste. 


\section{Rosidual Solid Produce (RSP)}

The objective of waste trealment is to change the chemical and/or physical form of a waste to render it more sale and/or environmentally sound. In addition, because of the land disposal restrictions, treatment is necessary to meet delined standards prior to disposal. The requirements for the residual from the incincrator are diflerent from those of the melter since each lechnology is intended to provide a dilferent function. Theretore, the criteria used for the two technology calcgeries will be dillerent for this allribule.

The incinerater need not produce a final dispossable waste form, but rather is intended to destroy the hazardous organic lraction of the waste and to proesss the bulk organic to prepare the material for feed 10 the melter. Thus the criteria are defined to judge a technology's ability to accomplish these goals. 'The organic destruction elficiency of the incinerators is evaluated, with those providing lor high organic burnout rated as superior. Since it is a goal of the melter process to keep oflgas treatment requirements $t(0)$ minimum, large quantities of residual organies are not a desirable feed for the melter process. The handling complexilies of the residual ash from the incinerators is also evaluated, as handling this material prior to feed to the melter process will be a concern. Finally the volume reduction potential of the technology is evaluated to aceount for those technologies that may require additives that will increase the final amount of material that must be treated.

For the melter, the residual solid product is the most important attribute, as producing a high quality disposable waste form is the goal of the process. There may be some amount of material that is fed to the melter that has hazardous organic contaminants. Thus, lechnologies that have demonstrated or are judged to able to provide proper destruction and removal efficiency (DRE) from the feed are given higher consicleralion. The control of process chemistry is also an important criteria, as it is anticipaled that there will be a desire to provide the capability to add glass formers or lluxes 6 control the melt viscosity and potentially other additives to optimize the structural and leaching properties of the final preduct. Technologies that allow for better chemistry control of the mollen pool are more desirable. Since leachability of the residual product is an important consideration, those lechnologies that have been demonstraled to produce a leach-resistant final form will be juclged somewhat higher than those that have not. And as in the case of the incinerators, those technologies that will lend to increase the overall disposable volume of waste will be slightly downgraded, as volume reduction of the final disposed waste is an important consideration.

\section{Orlgas Elfluent (EFL'I')}

The EFLT altribute was used to evaluate and compare the process eflluents of the lechnologies. A very significant aspect in the treatment of mixed TRU waste is control of the perential for release of both radiondive and hazardous constituents. The more problems created in the oflgas elfluents from a particular process, the more diflicult offgas treatment becomes, and the: grealer the posential for an unplanned release. Therelore, the EFft Teriterion seoring was structured 
10 favor technologies with inherent contamination control leatures that produce olfgasses requiring minimal treatment before release.

The eriteria for both the incincrators and the melters is basically the same in this attribute. The volume of eflluent generaled by a particular proeess is important as cechnolegies that generale relatively higher volumes of offgas will require more complicated and expensive offigas control systems. The potential for technologies to generate and carryover particulate to the offigas is evalualed since technologies that generate signilicant particulate create a difficult control situation in the capture and control of contaminated fly ash. Other important considerations include the potential for volatilization of heavy metals and radionuclides, control and capture of acid gasses such as $\mathrm{Hel}$, and the potential gencration of NOx, a particularly difficult class of compound to scrub from the offgas.

\section{Operational Considerations (OPS)}

The OPS altribute was included to evaluate various operational aspects that should be considered in cvaluating various technologies. These include process complexity, including simplicity of design and ease of operation, health and safety considerations involved in the processes, maintenance requirements, and potential level of throughput. The criteria for this attribute are the same in each of the technology categorics.

Process equipment complexily is considered important because it is assumed that the simpler a technology is, the more reliable and sale it will be. Similarly, if a system is easy to operate, it is likely that operalional problems that may lead $t o$ an event will be minimized.

The salety considerations cvalualed in this criterion were related to the inherent safely of the echnology. Technologies that operate at relatively low temperatures and pressures, produce a nondispersable waste form, and ofler structural pressure excursion containment were considered most salle. Inherent design features or process features that contribute to the control of radioactive material release is also an important consideration. This is primarily evideneed in the treatment vessel seal, and thus the ability to control contamination releases during pressure excursions. Technologics designed with this inherent leature are more desirable.

Maintenance requirements were evaluated because technologies operating on TRU contaminaled waste will have to be operated remotely most likely in glovebox enclosures. This requirement makes maintenane dillicult and would likely resule in increased radioactivity exposure for mainkenance personncl.

Finally, the throughput capability of cach lechnology was cvalualed ats part of this attribute. The throughput of a given technology is very diflicult to evaluate quantitatively because it is highly dependant on a number of individual variables, any of which will lead to a diflerent consideration for separate ecchonologies. The result is that numerical comparison of throughpul will not provide a 
meaningful comparison, and can thus be taken out of concext. Thus, this evaluation entails a qualitative treatment of the throughput ol each technology, consickring with size range of equipment available, (kechnologics having larger available capacity will be more desirable) and potential throughput lor a given processs size:

\section{$\operatorname{cost}(\cos 1)$}

In the cost attribute, the capital cest ol each lechnology was evaluated. 'The capilal eosts were estimated and evaluated based on a $10 \mathrm{MBtu} / \mathrm{ht}$ system using a consistent set of simplifying assumptions for each technology. The cost ligures were decermined based primarily from contacts with venders and developers, and from data available in published reports where applicable. While the cost data used in the evaluation is believed to indicale relative cest, they should be considered to be gress approximations at best. In the end, the cost of a particular technology is tikely to be a minor consideration at best, as its cost will be insignilicant in comparison to alpha lacility costs and ESikH and administrative costs. Thus, cost should not be a major contributor to the overall score.

\section{Woighting lagctors}

Cortain of the evaluation attributes can be defensibly judged to be of greater importance than others. In order to account lor this, relative weighting lactors are assigned to each altribute to account lor their relative importance. Each of the individual attribute raw secores is adjusted by its relative weight through a simple multiplicative operation. The resulting weighted attribute scores are then summed to provide the overall weighted score lor cach lechnology. These weighted seores are then mormalized on a () to 100 scale 10 provide better comparison.

Each of the two technology categories is intended to provide a different lunction for the remediation scenario being evaluated in this study. Therefore, dillerent weights were assigned to the altribute categories for the melter and the incinerator process to aceount for these diflering process reyuirements. The rationale lor the weights assigned is discussed below.

\section{Weighting Lactors for Incincralor Evaluation}

The primary purpose of the incineration process is to destroy the hazardous organics and to reduce bulk organic material. In this regard, the incineralor could be considered to be a preprocessor of feed material to the melter. In fact, an argument could be advanced that perhaps all the waste material retricued should be processed through the incineration system prior to introduction to the melter to assure a more homogeneous and readily processable feed to the melter. In this respect, the versatility of the incineration process becomes the most signilicant allribute, since the input waste could elfectively encompass the range of material to be retrieved from the RWMC. In addition, because the RWMC waste is contaminaled with transuranic iscolopes and other hatardeus materials 
that present signilicant personnel saldely and environmental problems, handling must be minimized. Versaltile technologies will reguire minimal predreatment and handling, reducing these risks.

The next important eriteria for the incineration processes are the operational considerations involved in the kechnologies. The eriteria display the overall operability and meatsure of health and sallely inherent to the lechnologies which are signilicant considerations. The more complex the process in operation, maintenance, and health and saldety concerns, the more dillicult the process will be 1 (1) permit and operate.

Level of develepment and eflluent evaluations were considered the next important attributes. These are raled somewhat lower in importance mostly because there are only subtle differences between each of the lechnologies in these altributes, and therefore, only a modest weighting of importance should be allorded in this calegery. The residual solid product allribute lollows next in importance. Since the incincrator is really only a prepresessing step for leced preparation to the melter process, the quality of the residual product is not of a major consideration. Finally, esest is the lowest consicleration in this study, as technology performance is a much grealer eonsideration than the cost, and cosit strould only be used as a last comparison for two identical performance lechnologics.

\section{Weighting Faglors for Moller Evalualion}

The goval of the melter process is 10 produce a final waste product that has optimum qualities lor control of leachability and structural inlegrity. Thus, the residual solid product eategory will obviously be the most important attribute of the echnologies, and will thus be given the highest weighling.

The next most important attributes are the versatility and the operational considerations for the individual processes. Versalitity is not quite as important as in the case of the incineration process, since the feed will be prepresessed into a somewhat mese homogenous feed stock; however, it is still an important consideration. Operational considerations are importane for the same reasons as discussed lor the incinerators.

Effluent considerations, fevel of development, and cost follow in order of decreasing importinne. Elfluent considerations become important in that it will be important assure that oflgats from the process will be readily controllable. Level of development will not be considered a particularly important concern in that most of the melter lechnologices are adatplations of well understend nen-waste trealment precesses, and it should be possible to last-track their development into waste treatment technologics. Finally, as discussed above, cost should not be an overriding liactor in the covaluation of the echnologies. 


\section{Appendix C}

\section{Evaluation of Technologies}




\section{.}




\title{
Appendix C
}

\section{Evaluation of Technologies}

\author{
EVALUATION OF INCINERATIORS
}

Level of Development and Availability

Rotary Kiln

The rotary kiln is the basis lor a perlect seore in this attribute, as this technology is the most commonly built and operated incincrator lor waste treatment (excluding liquid injection incinerators, which are lat more used in waste treatment, but are excluded from this study). Al least 75 commercial hazardous waste lacilities and 2 DOE facilitics are currently using rolary kilns. Thus, it is operational, conmercially available, and time proven.

\section{Controlled Air}

Controlled air incineration became popular in the 1960) and clearly meets the top seore in this criterion being operational, time-proven, and available commercially. At least 50 commercial hazardous waste lacilities and 4 DOE lacilities are currently using CAls.

Fluidized Bed

Fludized bed incincrator technology is operational, commercially available, and time proven. There are at least 25 FBls in operation on hazardous waste, and at least two that have been designed and esesed lor radieative waske (Rocky Flats and ICPP). FBI lechnology can be considered one of the more mature echnologies of those evaluated.

\section{Molten Salt}

Mollen salt incineralor lechnology is considered an emerging lechnology that has been demonstrated all a lield sciale. While the echnology has been around for a while and has been demonstrated, it is not yet available in commercial models. It has not been in any waste processing service, and is thus not time proven eilher. 


\section{Cyclone Incinerater}

('yclonic incineralion has been used for many years 10 process sludge waskes and clearly mocess the top score in this criterion being operational, time-proven, and availabte connercially, However, not lested on a bulk combustible waste fiorm.

Multiple: Hearth

The multiple hearth incincrator (MHI) technology is operational having had several construcled. MHIs have been used extensively in the treatment of sludge wastes, and are therefore time proven as well. However, the use of this technology has been largely abandened in favor of more versatile incineraters such as the rolary kiln and the technology is essentially not commercially available now. It could perhaps be brought back. Also not tested for this lype of waste form.

\section{Slagging Kiln}

(ienerally, slagging kiln lechnology is operational and commercially available. At least I0) slagging kilns are in operation on hazardous waste in the United States and several more are in the planning or constructions phase. Slagging kiln technology is very similar in application and operation to a rotary kiln process, for which a great deal of operational experience exists. The technology is commercially available, but is should not be considered as time proven.

Cyclonc Melter

The eyclone melter is derived frem cyelone burner lechnology used in the coal fired electrical energy generation plants. It has been demonstrated at a lield scale for waste applications, but is not an operational technology. The cyclone melter is a derivative application of the cyclone incinerator. and is, therefore, commercially available. However, it is not a lime proven waste applicaltion lechnolegy, and has not been lested lor this waste. 
Summary of Level of Development and Availability Scoring

\begin{tabular}{|l|c|c|c|c|c|}
\cline { 2 - 5 } \multicolumn{1}{c|}{} & \multicolumn{4}{c|}{ Criteria Scros } & Total \\
\cline { 2 - 6 } \multicolumn{1}{c|}{} & $\begin{array}{c}\text { Dev stg } \\
(1,2)\end{array}$ & $\begin{array}{c}\text { Tested } \\
(0,1)\end{array}$ & $\begin{array}{c}\text { Comm } \\
(0,1)\end{array}$ & $\begin{array}{c}\text { Proven } \\
(0,1)\end{array}$ & $\begin{array}{c}\text { Score } \\
(1,5)\end{array}$ \\
\hline Rotary Kiln & 2 & 1 & 1 & 1 & 5 \\
\hline Controlled Air & 2 & 1 & 1 & 1 & 5 \\
\hline Fluidized Bed & 2 & 1 & 1 & 1 & 5 \\
\hline Molten Salt & 1 & 0 & 0 & 0 & 1 \\
\hline Cyclone & 2 & 0 & 1 & 1 & 4 \\
\hline Multiple Hearth & 2 & 0 & 0 & 1 & 3 \\
\hline Slagging Kiln & 2 & 1 & 1 & 0 & 4 \\
\hline Cyclone Melter & 2 & 0 & 1 & 0 & 3 \\
\hline
\end{tabular}

\section{Versatility}

\section{Rotary Kiln}

The rotary kiln is probably the most versatile of the conventional types of incinerators. Most commercial hazardous waste applications h.undle liquids, solids, and sludge wastes routinely without the need lor pretreatment. Whole 55 -gal drums of waste are typically fed to large applications of rotary kilns (i.e. units greater in thermal rating than approximately $50 \mathrm{MMBtu}$, a very large unit). Rotary kilns are also the technology of choice for many soil remediation applications, often without pretreatment. exeept for grinding large pieces into smaller size to increase surface area and thus mass transfer.

\section{Controlled Air}

The CAI is not an extremely versatile technology. They are applied primarily to combustible waste with low ash contents because of drawbacks in their ability to handle large quantities of residual ash. Soils could be treated in the CAI, but likely only in small quantities. Tramp metals are best exeluded. Pretreatment shredding is not extensive, only lor very large objects. Feed of whole drums is not leasible. 


\section{Fluidized Bed}

FBI technology is considered an omnivorous technology with the ability to handle most types of RWMC combustible waste. One exception would be high density materials such as metallic wastes, which would drop to the bottom of the bed where they may cause operational problems. This will present a problem if tramp metals are in the waste, requiring excessive screening and removal. Bulk combustible waste is readily processed in a fluidized bed; however, only with shredding prior to feeding. Contaminated soils are suitable for processing in a fluidized bed, but must be crushed to a relatively fine state.

\section{Molten Salt}

The molten salt incinerator is applicable only to low-moisture, low-ash wastes. Therefore, a molten salt incinerator would be applicable to only the bulk organic fraction of the combustible waste. Soils and high moisture sludges would not be readily processable. In addition, pretreatment would be required for the combustible wastes.

Cyclone Incincrator

The Cyl is not a versatile incinerator. They are applied primarily to sludges, liquids, and gaseous wastes because of their lack of ability to handle large quantities of residual ash. The technology is not suited to processing bulk organics. Soils and sludges could be treated, but would require extensive size reduction. Therefore, only a small fraction of combustible waste could be treated with this technology.

Multiple Hearth

The MHI technology wa: designed primarily for use on sludge waste. While it could also he used on other types of waste, its use is limited primarily to sludge type wastes. It could probably process a the soil component, and perhaps some of the bulk organies; however, pretreatment would be required. Tramp metals may pose a problem.

\section{Slagging Kiln}

The slagging kiln is considered to be an omnivorous technology. No pretreatment would be required for most lypes of RWMC wastes being considered in the combustible waste category. Items such as whole drums of the organic/calcium silicate sludge could feasibly be fed directly without pretreatment; however, increasing metal content in the feed has a direct impact on producing a molten product. It is better if metals are excluded from the feed. Slagging kilns are most often utilized when processing waste having a high inherent heating value, particularly organic sludge type wastes (e.g., from oil refincries). The RWMC combustible waste has only a moderate heating value, which will require much supplementary fuel and oxygen enriched operation. In general, a slagging 
kiln will not be used in applications involving signilicant quantilies of soil or other non-combustible malcrial.

\section{Cyclone Melter}

Larger tramp metallic objects and bulk organic materials will not be effectively processed based on the difficulty of introducing the materials to the process (via pneumatically conveyed feed stream), and short retention time in the chamber. Pretreatment requirements will be very high to condition feed stream. Feed of soils and sludges should be acceptable.

\section{Summary of Versatility Scoring}

\begin{tabular}{|l|c|c|c|c|}
\cline { 2 - 4 } \multicolumn{1}{c|}{} & \multicolumn{2}{c|}{ Criteria Scores } & Total \\
\cline { 2 - 5 } \multicolumn{1}{c|}{} & $\begin{array}{c}\text { Fraction } \\
(1-3)\end{array}$ & $\begin{array}{c}\text { Screen } \\
(0,1)\end{array}$ & $\begin{array}{c}\text { Pretreat } \\
(0,1)\end{array}$ & $\begin{array}{c}\text { Score } \\
(1,5)\end{array}$ \\
\hline Rotary Kiln & 3 & 1 & 1 & 5 \\
\hline Controlled Air & 2 & 0 & 1 & 3 \\
\hline Fluidized Bed & 2 & 0 & 0 & 2 \\
\hline Molten Salt & 1 & 0 & 0 & 1 \\
\hline Cyclone & 2 & 0 & 0 & 2 \\
\hline Multiple Hearth & 2 & 1 & 0 & 3 \\
\hline Slagging Kiln & 3 & 1 & 1 & 5 \\
\hline Cyclone Melter & 2 & 0 & 0 & 2 \\
\hline
\end{tabular}

\section{$\underline{\text { Residual Product Form }}$}

\section{Rotary Kiln}

The lurbulent action of the waste products moving through the kiln and the high combustion air rales in the kiln provide for excellent burnout and destruction of organics. Rotary kiln incincrators are BDAT for the organic constituents found in RWMC waste. However, they p: ciduce a dispersible ash that would present moderate considerations in handling to control migration. Volume reduction can be aceomplished by destruction of the organic materials and by the production of a more homogenous stream. 


\section{Controlled Air}

CAIs are BDAT for the organic constituents found in RWMC waste, and can be operated to achice a very high degree of organic burnout and destruction. CAls produce an ash that would tend to be dispersible, but often forms a somewhat hardened "elinker" material. Volume reduction is accomplished by destruction ol the organic materials and by the production of a more homogenous stream.

\section{Fluidized Bed}

The FBI is BDAT for the organic contaminants involved in RWMC waste, and the highly turbulent nature of the bed yield very high destruction efficiency. The abrading action of the lurbulent bed causes grinding of the residual ash into a fine state, creating potential handling coneerns; however, the fluidizable material should be readily conveyed by pneumatic methods using sealed transport mechanisms. The FBI may not aceomplish the same degree of volume reduction as other incinerator technologics because of bed material may have to be added to maintain adequate bed characteristics; however, sand is generally used as bed material, and the soil feed may adequately form sulficient bed material.

\section{Molten Salt}

The molten salt incincrator produces a spent salt final waste form, which contains the residual ash from the combustion. It is not elear whether burnout of organic material is very high, but probably is. Because the spent salt becomes part of the final waste, the final waste volume is increased. Extreme handling and treatment is required to bring the effluent into a state to prepare it for feed to the melter.

Cychone Incincrator

CYIs are BDAT for the organic constituents found in RWMC waste, but burnout of bulk organics may not be accomplished in the short solids residene time of the primary chamber. The CYI produces a dispersible ash that would require special handling. Volume reduction can be accomplished by destruction of the organic materials and by the production of a more homogenous stream.

Multiple Hearth

The MHI is BDAT for the organic contaminants involved in RWMC waste, and should provide sullicient solids residence time 10 ensure burnout of organics. Again, a dispersible ash is gencrated, which will require handling considerations. Volume reduction will be achicved similar to other incinerallors. 


\section{Slagging Kiln}

The slagging kiln should provide the proper destruction of organics that will be required. A slagging kiln may result in a waste form that is likely to meet the performanee standard for leachable metals, and would thus be directly disposable. The vitrification will help produce a stabilized and thus more easily handled ash product. Because of the loss of void space from vitrification, slightly higher volume reduction is also achicecd, but this is oflset by the addition of fluxing agents to reduce the melting point of the slag, potentially leading to greater volume that other non-vitrilying incinerators.

\section{Cyclone Melter}

The eyclone melter has a very short residene time of material in the process zone, and woukd not provide the time necessary to provide complete burnout of bulk organic material. Handling of the residual solidified material, however, will be optimal, with little dispersion potential. Final volume will not be minimized as additives are needed to assure product is brought to a molten state.

\section{Summary of Residual Solid Product Scoring}

\begin{tabular}{|l|c|c|c|c|}
\cline { 2 - 5 } \multicolumn{1}{c|}{} & \multicolumn{3}{c|}{ Criteria Scores } & Total \\
\cline { 2 - 5 } \multicolumn{1}{c|}{} & $\begin{array}{c}\text { Organic } \\
(1,2)\end{array}$ & $\begin{array}{c}\text { Handling } \\
(0-2)\end{array}$ & $\begin{array}{c}\text { Vol. Red. } \\
(0,1)\end{array}$ & $\begin{array}{c}\text { Score } \\
(1,5)\end{array}$ \\
\hline Rotary Kiln & 2 & 1 & 1 & 4 \\
\hline Controlled Air & 2 & 1 & 1 & 4 \\
\hline Fluidized Bed & 2 & 1 & 1 & 4 \\
\hline Molten SaIt & 2 & 0 & 1 & 2 \\
\hline Cyclone & 1 & 1 & 1 & 3 \\
\hline Multiple Hearth & 1 & 1 & 0 & 4 \\
\hline Slagging Kiln & 2 & 2 & 0 & 3 \\
\hline Cyclone Melter & 1 & 2 & 0 & 3 \\
\hline
\end{tabular}




\section{Ofligus Elfluonts}

\section{Rotary Kiln}

Rotary kilns are noted for high exeess air rates in order to ensure destruction. This results in large volumes of offgas and, combined with the tumbling of waste in the chamber, high carryover of particulate from the incinerator into the offgas system. This requirement results in the need for complex offgas systems to ensure removal consistent with radioactive material. Some amount of metal volatilization and Nox formation will oceur, but not extensive. Chlorine in the waste feed will preduce acid gas that will need to be scrubbed.

\section{Controlled Air}

CAls were designed to provide very good eontrol of particulate material generation and carryover. This is accomplished through low air rates in the primary and a relatively quiescent' burning bed. Hel will be formed and will need to be scrubbed. Lower temperatures lead to minimal formation of metals and Nox, and thus only moderate offgas system requirements. For these reasons, CAI has often been chosen as the preferred technology for combustible radioactive waste.

\section{Fluidized Bed}

The FBI does not produce a great volume of olfgas. However, the inherent design leads to relatively high gas velocities, which, combined with the abrasion of bed malerial, result in the high carryover of particulate contaminants into the oflgas system. Because of the high particulate carryover rate associaled with FBls, a high temperature cyclone is always employed at the exit. The cyclone is necessary to return bed material to the bed and in this capacity, is considered part of the FBBI. However, because cyclones are not effective on submieron particulate, the particulate removal requirements downstream are considered complex. In-bed chlorine scrubbing in FBIs is usually employed by adding a lime feed to the bed, reducing ofligas scrubbing requirements. In addition, the chlorine removal in the bed reduces the available chlorine to form metal chlorides, which are more volatile than metal oxides. This may reduce the carryover of heavy metals into the offgas and therefore, the offgas treatment requirement for this contaminant. Low operating temperatures produce little Nox.

\section{Molten Silt}

Because combustion takes place within a molten matrix, combustion efliciency is very high, and particulate control is very high. Combustion volumes are relatively low. In-bed scrubbing of chlorine is aceomplished, and because the salt forms complexes with heavy metals and radionuclides, they are retained in the salt. Low temperature eperation will minimize formation of $\mathrm{Nox}$ and motal volatilization. 
Cyclone Incineralor

CYIs are designed lo operate with a very high turbulence, leading to a very high destruction efficiency and thus requiring a minimal volume of combustion air. Cyls are noted lor very good control on particulate, due to the cyclenic turbulenee which centrilugally de-entrains particulate. CYls will produce a relatively high temperature combustion zone that will lead of formation of relatively higher quantities of metals and NOx. HCl scrubbing will be required. Olfgats considerations are moderate.

Multiple Hearth

The $\mathrm{MH}$ is operated with relatively moderate exeess air rates, which lead lo relatively small volumes of offigas. Particulate generation is not extreme dee lo low air rates and design of the system where olfgas from the combustion zone passes through a relatively cold feed material zonc. This should also help control metal volatilization and NOx. HCl will have to be scrubbed. Offgas considerations are judged to be low.

\section{Slagging Kiln}

Orlgas treatment for the slagging kiln is considered to relatively less complex than for a rotary kiln because of lower excess air rales which result smaller volumes of offgas. This and the slagging action of the waste result in less particulate generation and earryover. The offgas treatment reguirement of the slagging kiln is given a moderate because of the high temperature gas handling requirement, requiring special materials, consideration for metal volatilization and Nox generation. Again, HCl will have lo be scrubbed.

Cyclone Melter

Due 10 the efficiency of mixing and turbulence, the eyclone melter requires smaller yuantities of excess air. However, the high turbulence and small leed material size required will kad to particulate formation and entrainment. The relatively higher process zone temperatures will create some concerns in the formation of NOx and the volatilization of heavy metals. Offgas concerns would be moderale. 
Summary of Eflluene sooring

\begin{tabular}{|l|c|c|c|c|}
\cline { 2 - 5 } \multicolumn{1}{c|}{} & \multicolumn{3}{c|}{ Criter1a Scores } & Total \\
\cline { 2 - 5 } \multicolumn{1}{c|}{} & $\begin{array}{c}\text { Volume } \\
(1,2)\end{array}$ & $\begin{array}{c}\text { Part. } \\
(0,1)\end{array}$ & $\begin{array}{c}\text { Other } \\
(0-2)\end{array}$ & $\begin{array}{c}\text { Score } \\
(1,5)\end{array}$ \\
\hline Rotary Kiln & 1 & 0 & 1 & 2 \\
\hline Controlied Air & 2 & 1 & 1 & 4 \\
\hline Fluidized Bed & 2 & 0 & 2 & 4 \\
\hline Molten Salt & 2 & 1 & 1 & 5 \\
\hline Cyclone & 2 & 0 & 1 & 3 \\
\hline Multiple Hearth & 1 & 1 & 0 & 3 \\
\hline Slagging Kiln & 2 & 1 & 0 & 2 \\
\hline Cyclone Melter & 2 & 0 & & 3 \\
\hline
\end{tabular}

\section{Operational Considerations}

\section{Rotary Kiln}

Complexity: In comparison to other technologies, the rotary kiln is a relatively complex process, particularly the moving kiln system.

H\&S: Rad control is questioned on rotary kilns, particularly for the rotating scal. Potential pressure excursions may lead to releases through the seals.

Maintenance: Downgraded for higher than normal refractory maintenance requirements, maintenance of seals and moving parts.

Throughput: Rotary kiln will have a relatively high throughput capacity compared to other echnologics. Process unit sizes are available to very large capacities.

Controlled Air

Complexily: The CAl is a relatively simple process. Basically simple system to operate. Air leakage into the primary chamber is a common control problem.

H\&S: Downgraded for production of a dispersible ash. Potential for release an pressure excursions i.c. not a sealed vessel.

Maintenance: Generally a low maintenance devices, even if operaled with frequent themal cycling. 
Throughput: CAIs will have a moderate throughput level. Sizes range lange. Relatively long solids residence time is required for complete burnout.

Filudized Bed

Complexity: FBls are a very simple design, having few moving parts. Good thermal stability due (1) heat capacity of the bed is chatacteristic. Operation is somewhat difficult in transient conditions in maintaining fludization of bed. Bed can agglomerate and catuse a situalion of l'recze-up.

HaS: Low temperature but produces a readily dispersible ash. Units are better sealed than other processes, even designed to operated at slightly positive pressures without releases.

Mainlenance: Fludizing air inlel orifieses will deteriorate with time requiring replacement. Lower temperatures should reduce refractory were, but should be offsed by abrasive nature of the bed. No moving parts to process recpuiring service and repair.

Throughput: Since FBIs are very ellicient at transferring heat to the waste, they will provide a higher throughpul capability than other technologies. Sizes range to very large units.

Molten Sill

(omplexily: Handling of high temperature molten malerial is a consideration. Offgas unit operation will be very complex. Handling of residual solid product complicated. There is polential for bed frecez-up for some high melting compounds.

II\&S: Downgraded for mollen material handling. Scaled process vessel provides increased contamination control of ash

Maintenance: Will have materials compalibility problems with high temperature molten salt. long-term mainenance requirements are unknown.

'Throughpul: Effective means of transferring heat to waste should provide relative economy of throughpul for a given size. Unit sizes will not be very large; multiple units will be required for operolions.

('yclone Incincrator

Complexily: The process is relatively simple 10 operate since product is air conveyed and no moving parts are needed. Extensive leed preparation; however, adds some complexity. Basically a simple system to operate.

HeS: Process operales as a sealed vessel. Downgraded for production of a dispersible ash.

Maintenance: Low mainlenanec deviecs even with frecguent thermal eycling. High temperalure process zone will lead to relatively more frequent relactory wear. 
Throughput: Throughput limited by ash handling capability. Unit capacitics available are quite large. In general, moderate throughput polential.

Multiple Hearth

Complexity: Air cooled rotating rabble arms in the chamber are used to move waste through process. Control on a highly variable waste leed type may be diflicult.

H\&S: $\quad$ Moderate temperatures but produces a dispersible ash. Vessels will not be totally sealable.

Maintenance: Moderate maintenance requirements due to internal moving parts. Refractory wear not a large issue.

Throughput: For the waste types evaluated, throughputs should be moderate. Systems are produced in moderate capacity sizes.

Slagging Kiln

Complexity: Handling of high temperature molten material a moderate complexity. Special materials required. Maintaining molten slag chemistry a operating concern. Rotating kiln problems same as rotary kiln. Oxygen enrichment or preheated combustion air required for adequate operation.

H\&S: Downgraded due to special high temperature and molten material. Slightly increased contamination control of vitrified ash. Potential for release on pressure excursion.

Maintenance: Refractory maintenance requirements will be extreme. Kiln seal maintenanec requirements high.

Throughput: High throughput potential, large capacity units.

Cyclone: Melter

Complexity: The process is relatively simple to operate since product is air conveyed and no moving parts are needed. Extensive feed preparation; however, adds some complexity. Preparing and feeding glass forming additives adds to complexity.

H\&S: Process operales as a sealed vessel. Provides for vitrification/agglomeration of ash, thus minimizes dispersion potential.

Maintenance: Low maintenance devices even with frequent thermal cycling. High temperature process zone will lead to relatively more frequent refractory wear.

Throughput: Throughput limited by ash handling capability. Unit capacities available are quite large. In general, moderate throughput potential. 


\section{Summary of Operallonal Considerations Scoring}

\begin{tabular}{|l|c|c|c|c|c|}
\cline { 2 - 5 } \multicolumn{1}{c|}{} & \multicolumn{4}{c|}{ Criterla Scores } & Total \\
\cline { 2 - 6 } & $\begin{array}{c}\text { Comp } \\
(1-3)\end{array}$ & $\begin{array}{c}\text { H\&S } \\
(1-3)\end{array}$ & $\begin{array}{c}\text { Madnt } \\
(0-2)\end{array}$ & $\begin{array}{c}\text { Thrpt } \\
(0-2)\end{array}$ & $\begin{array}{c}\text { Score } \\
(1,5)\end{array}$ \\
\hline Rotary K1In & 3 & 1 & 1 & 2 & 3.5 \\
\hline Fontrolled Air & 3 & 2 & 2 & 1 & 4 \\
\hline Molten Salt & 2 & 2 & 1 & 2 & 3.5 \\
\hline Cyclone & 1 & 2 & 1 & 0 & 2 \\
\hline Multiple Hearth & 2 & 2 & 1 & 0 & 2.5 \\
\hline S.lagglng Kiln & 2 & 2 & 1 & 2 & 3.5 \\
\hline Cyclone Melter & 1 & 2 & 0 & 2 & 2.5 \\
\hline
\end{tabular}

\section{Cosit}

Rotary Kiln

The rotary kiln is a moderate cost lechnology, experiencing some additional cost drivers bascel on kiln and seal difficulties. Feed handling equipment minimal.

\section{Controlled Air}

A simple design, simple constructed system, will be among the lowest of cosst.

fluidised Bed

Also a simple design, with lew moving parts.

Mollon Silt

Highly complex process that has not been eonstructed on any kind of routine basis. Will require special materials of eonstruction due to extreme process envirenment. Will be one of the highest cost ecchmologics.

(yelone Incinerater

The special feed sysem conliguration, and additional feed preparation equipment will atde ar the cost, driving the technolegy 6 a moderale cost rating. 
Multiple Hcarth

Will also be a moderate cesst facility, as not many have been made recently, and also requires foed preparation equipment.

Slagging Kiln

Special materials of construction concerns and product handling system will drive the cost for the slagging kiln to the higher end of esst.

Cyclone Melter

Again, special materials of construction and product handling system coneerns will drive the lechnology to the higher end of esst.

Summary of Cost Scoring

\begin{tabular}{|l|c|}
\cline { 2 - 2 } \multicolumn{1}{c|}{} & $\begin{array}{c}\text { Total } \\
\text { Score } \\
(1,3,5)\end{array}$ \\
\hline Rotary Kiln & 3 \\
\hline Fontrolied Air & 5 \\
\hline Molten Salt & 5 \\
\hline Cyclone & 1 \\
\hline Multiple Hearth & 3 \\
\hline Slagging Kiln & 3 \\
\hline Cyclone Melter & 1 \\
\hline
\end{tabular}




\section{IVVALIIAIION OF MLLIERS}

\section{Level of Develomenent and Availability}

finsil fucked Hearth Molser

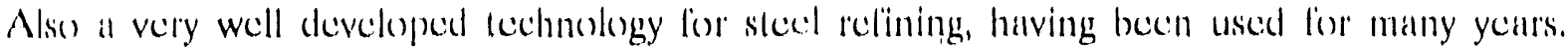
Processes are commercially avidibble.Not demenstraled on waste processing in any greal detail, and cannen be considered time proven for waste applications.

Plasma lorch Ilearth Molter (P'THM)

The PTHM is a technolegy that has been used lor many years in the metals produclion industry. P'THM is an emerging technology in the area of waste treatment, and has been demonstrated at what can be considered to be lield scale. Equipment is commercially available from a number of venders. The echnology has been demonstrated on several elose variations of the lype of waste being considered. It is not a time-proven waste trealment technology.

\section{Graphite Lilectrode Hearth Melter (GEHM)}

The (iliHM is a cechnology that has been used for many years in the production and recyeling of stecl. Some limiled work in the area ol waste trealment has been done for what can be considered liekd scalle. The lechnology is commercially available and, based on sted operations, can be said lo be lime preven.

Fossil fincled Shalt Moller

A well understood and developed process for scrap steel recycling and precessing. Technolong is operational; however, has not been demonstrated on waste applications. Equapment is commercially available, but is not lime proven on waste applications.

\section{Plasma l'orch Shall Meler (P'ISM)}

P'TSM lechnology is gaining experience in waste treatment technolengy, principally in trealment of waste melal. However, the lechnology should still be considered demonstrated all lield scale, as only one processing system has been built recently. Equipment is commercially available, but the: echnolegy cannot be said to be time preven. 
(iraphile: Likectrode Shalt Molter (GliSM)

A novel adaptation of a woll used shall melter ecthonology, having thus far only to be demenstrated at the liede scale. Has been demenstraled on a basically combustible waste matrix. Equipment is not commercially available ut this time, and the lechnology is not time proven.

Joule-Heated Melter (JHM)

The JHM is operational and commercially available as "glass production technology. As a derivative of technology utilized lor glass making, there are more than $8($ ) units throughout the world. Equipment is commercially available. Several waste treatment applications are being pursued, but the technology cannot be sald to be an operational waste treatment technology. Since there is only one unit processing hazardous waste, the system is not lime-proven.

\section{Microwave Molter}

The microwave meller is (on selected homoggeneous waste streams) an emorging technology which has been demonstrated at pilot scale at the Rocky Flats Plant and in Japan. The technology is not available commercially or time-proven.

Mollen Melal Bath

A derivative of sted making technology, this lechnology relies on a molen sted bath for processing of the waste. The technology itsell is malure, but has not been demonstrated for waste trealment. Equipment can be said to be commercially available, but the technology is not time proven.

Cyclone Melter

The eyclone meler has been demonstrated at a lield scale, but is not an operational lechnology. The cyclone meller is a derivative application of the cyclone incincrater, and is therefore commercially available. However, it is not a time proven technolegy.

\section{Slagging Kiln}

Gencrally, slagging kiln echnology is operational and commercially available. At least I0) slagging kilns are in operation on hazardous waste in the United States and several more are in the planning or construclions phase. Slagging kiln technology is very similar in application and operation to a rotary kiln process, for which a greal deal of operational experience exists. The technology is commercially available, but should not be considered as time proven. 
Summary of Scoring for Level al Development

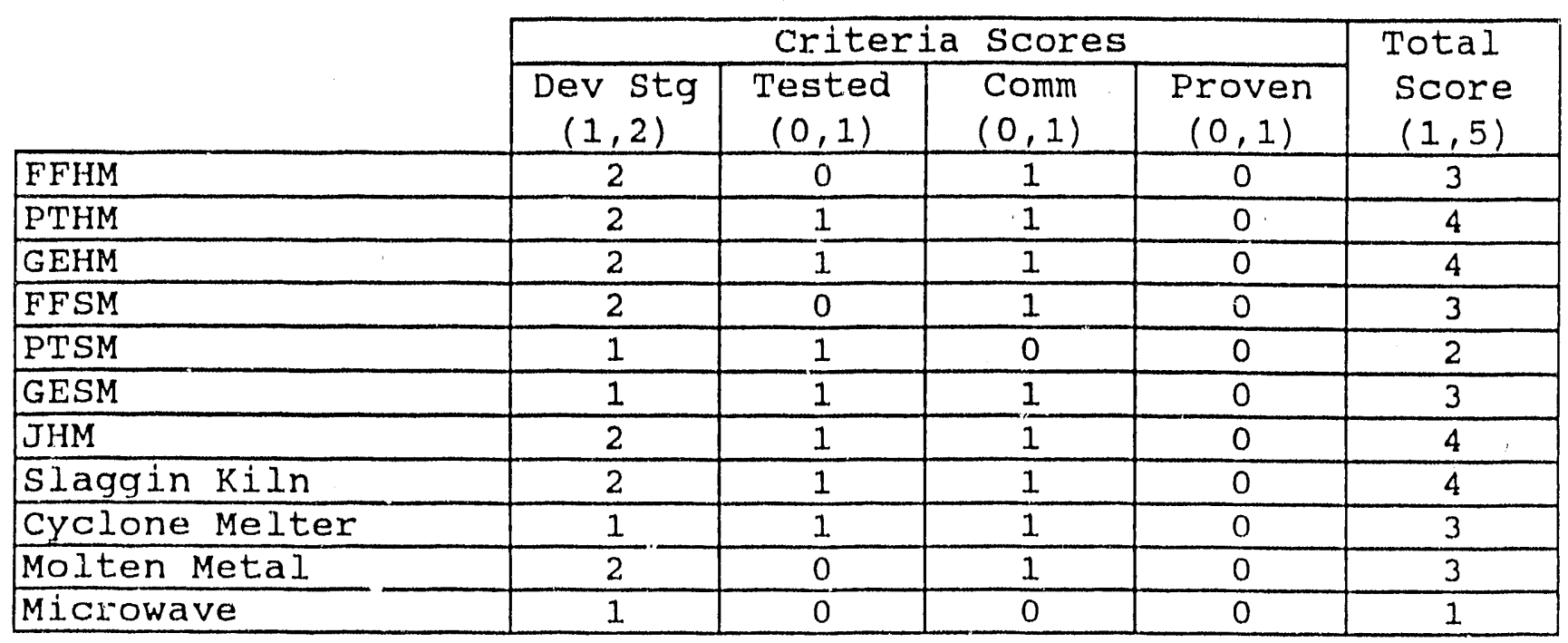

\section{Versiatility}

Fossil Fueled Hearth Melter

None of the subject waste feed being eonsidered should present a probiem for feeding to the process. Pretreatment requirements will be minimal. Variability in leed should not pose a problem to operation of the system. Upper temperature range is high so that melt temperature is flexible.

Plasma Torch Hearth Melter

Although its versatility has not been proven completely, the PTHM is eonsidered to be an omnivorous lechnology. It is claimed to be capable of handling any of the waste associated with the RWMC: Plasma systems have been demonstrated on soil matrices with minor organic and metallic contaminants, as expected in the RWMC incrt waste. Bulk sludges have not been demonstrated, but should pose no special problems. Waste pretreatment should be minimal. Feed variability would appear to pose no problem in the system. Upper temperature sange is very high, leading to particular llexibility in operation. 


\section{Graphite Electrode Hearth Meller}

In this calegory, there is no apparent dillerence between the P'THM and the GEHM. The same description as above applies.

\section{Fossil Irueled Shalt Melter}

The FFSM should be able to adequately process any of the materials being considered. Pretreatment requirements will be relatively high, based on optimal densification of the waste material and carcful control of fuel assist material. Feed variability may tend to cause operational problems due to lack of eontrol lunctions. Data indicate that not significantly high temperature ranges are allainable.

\section{Plasma Torch Shaft Meller}

The P'TSM should also not be limited by any of the postulated material feed. Pretreatment will also be high in this application. Feed variability will not likely be as much of a concern as controlling the torch will control the process parameters. Potentially higher temperatures may be obtained with plasma assist.

\section{Ciraphite Electrode Shatt Melter}

Same discussion as PTSM applies here.

\section{Joule-Hleated Melter}

The glass furnace is an omnivorous technology within its temperature range and is capable of processing all of the waste types present at the RWMC. It is less well suited to high eonecntrations of metals and high melting temperature soils, requiring flux additives to eontrol melt viseosity.

Microwalve Meler

The mierowave melter has been demonstrated only on sludges and fincly divided inerts (ash). It is not capable of effectively processing tramp combustibles or nonuniform incrts. Pretreatment requirements are high for the material to be processed. Variability of feed material is not likely (o) be a greall concern. Upper temperature range is limited.

\section{Mollen Metal Bath}

The molten metal bath technology should not have a problem with any of the waste components heing considered here, except possibly the hydrated sludges, due to satety concerns. Waste 
pretrealment will be recpuired ler some larger bulk objects 10 allow lheir leed below the mell surlace as designed. Feed variability shoukd be no problem. Upper lemperature range is high.

Cyclone Melter

Larger tramp metallic objects and bulk organic materials will not be effectively processed based on the difliculty of introducing the materials to the process (via pneumatically conveyed feed stream), and short retention lime in the chamber. Pretreatment requirements will be very high to condition feed stream. Variability of feed will be a concern from a control standpoint as fuel requirements will difler. Upper temperature range is limiled, limiting versatility.

\section{Slagging Kiln}

The slagging kiln is considered to be an omnivorous technology. No pretreatment would be required for most types of RWMC wastes being considered in the inerl waste callegory. Increasing metal content in the feed has a direct impact on producing a molten product. It is better il metals are excluded from the feed. Slag forming materials have to be added to the leced. Pretreatment requirements are relatively high. Feed variability may cause problems as sulficient formers are needed lo ensure proper operation. With temperatures commonly approximating 250()$^{\circ} \mathrm{F}$ the slagging kiln is not a very high temperature process.

Summary of Versalility Scoring

\begin{tabular}{|l|c|c|c|c|c|}
\cline { 2 - 5 } \multicolumn{1}{c|}{} & \multicolumn{4}{c|}{ Criteria Scores } & Total \\
\cline { 2 - 6 } \multicolumn{1}{c|}{} & $\begin{array}{c}\text { Wst Ex } \\
(1,2)\end{array}$ & $\begin{array}{c}\text { Pre-Tr } \\
(0,1)\end{array}$ & $\begin{array}{c}\text { Var } \\
(0,1)\end{array}$ & $\begin{array}{c}\text { Temp } \\
(0,1)\end{array}$ & $\begin{array}{c}\text { Score } \\
(1,5)\end{array}$ \\
\hline FTHM & 2 & 1 & 1 & 1 & 5 \\
\hline GEHM & 2 & 1 & 1 & 1 & 5 \\
\hline FFSM & 2 & 1 & 1 & 1 & 5 \\
\hline PTSM & 2 & 0 & 0 & 0 & 2 \\
\hline GESM & 2 & 0 & 1 & 1 & 4 \\
\hline JHM & 2 & 0 & 1 & 1 & 4 \\
\hline Slagging Kiln & 1 & 1 & 1 & 0 & 3 \\
\hline CyClone Melter & 2 & 1 & 1 & 0 & 4 \\
\hline Molten Metal & 1 & 0 & 1 & 0 & 2 \\
\hline Microwave & 2 & 1 & 1 & 1 & 5 \\
\hline
\end{tabular}




\section{Residual Product Forme}

Fossil Fueled Hearth Melter

The potential lo establish proper DRE has mot been done for this technology. (hemistry should be readily controllable for achiceving desired outpul. Demonstraled leaching data of residual product does not appear to exist. The potential for volume reduction should marginal based on the need for additives 10 lower process temperatures and addition of ash from fuel where coke is used.

\section{Plasma Torch Hearth Melter}

The P'THM should be capable of meeting DRE lor organics, and, based on preliminary data, at least one current project should determine this. Chemistry of the melt should be readily controllable, particularly when considering the option of using differing plasma gasses. The PTHM produces a vitrified ash waste lorm which has been demonstrated to exhibit favorable leaching characteristics. Because of the loss of the loss of void space from vitrification and the lack of need for lluxes lo obtain lower temperature melting, volume reduction is achieved.

\section{Graphite Electrode Hearth Melter}

Based on some PCB testing, DRE potential appears to be readily obtainable. Chemistry control of the melt should be easy 10 aceomplish. Currency leaching data from residual slag appears to be: lacking. For the same reasons as the PTHM, volume reduction is obtained.

Iossil Fucled Shaft Melter

The shalt meleers will all appear to be inflexible as to the fate of metals in the residual. Chemistry control will be diflicult to elfect based on preleceding materials and short column residence limes. Leaching data has not been displayed. Volume reduction will not ocecur as additive malerials will be necked to assure proper melting.

\section{Plasma Torch Shalt Melter}

The same basic discussion applies as lor the fuel lired shaft melter. The exception is that higher cemperatures are possible, and the overall volume should be smaller due to the lack of need for lluxcs.

Giaphite Liketrode Shalt Melter

The same basic discussion applies as for the fuel fired shaft melter. The exception is that higher emperalures are pessible, and the overall volume should be smaller due to the lack of need for Huxes. 
Jouk-Healed Meller

Metals could be oxidized in the JHM or allowed to collect at the bollom ol the vessel for removal. Chemistry is readily controllable in this technology, and it has been demonstraled to provide a highly leach resistant product. Because of the addition of glassmaking materials, the final volume will increase.

\section{Microwave Meller}

The microwave will not be llexible in its handling of tramp metals. Chemistry control is somewhat obtainable lor the molten product. Leach data doesn't appear to have been obtained. Fluxing agents will be needed to produce the molten product from the high melting point INEL. constituents.

\section{Molten Metal Bath}

Control of the metal fraction of the waste is actually not applicable, but a lavorable score will be granted. Chemistry eontrol of the slag is touted as one of the prime benefits of the technology. No leaching data is available, as the echnology is so new. Volume reduction of the material is obtained sine temperatures shoukt be high enough to provide melting without lluxes.

Cyclone Melter

Control of the metal fraction is not leasible for this technology. Chemistry control would be very diflicult to effect based on the need to preleed materials and the very short process zone residence time. Leaching tests have been conducted on some waste matriess. Volume reduction probably not be oblained based on the need for lluxes.

\section{Slagging Kiln}

Again, control of the metal lraction is not feasible for this technology. Chemistry control would be very difficult to eflect based on the need to prefeed materials into the process, thus estimating proper chemistry with no method to make changes. Leaching lests have been conducted on some waste matrices. Volume reduction probably not be obtained based on the need for fluxes. 


\section{Summary of Residual Solid Product Sororing}

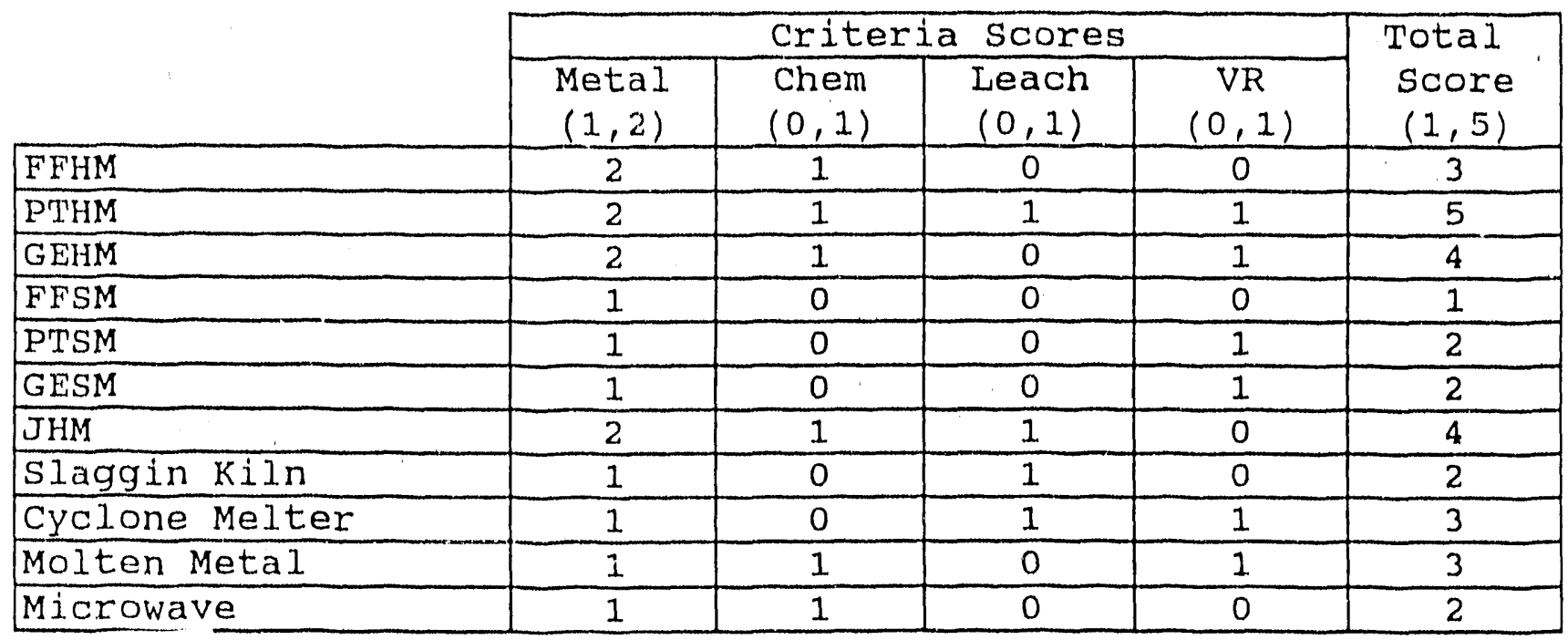

\section{Ofligas Ellluents}

Fossil rucled Hearth Melter

Being a fossil fueled process, the volume of the offgas will be high. A relatively large fraction of particulate can be expected based on the use of eoke for processing. The process is not particularly high temperature, and should create litte concerns in offgeds handling, execpt for the size of the system.

Plasma Torch Hearth Mclter

Being an electrical process rather than a lessil fuel fired process, the PTim produces lar less oflgas volumes. Due to the low air rales in the primary, particulate entrainment and carryover should be reduced. Plasma systems operating on air have a endency to produce high levels of NOx. however, olher torch gasses can be used. The very high temperatures of the process have a ingh cendency to volatilize heavy metals. Overall, ollgas considerations are moderate. 
Graphite Electrode Hearlh Meller

Similar arguments apply for the GEHM as the P'THM above.

Fossil Fueled Shalt Melter

Being a lossil fueled process, the volume of the offgas will be high. A relatively large fraction of particulate can be expected based on the use of eoke for processing. The process is not parlicularly high temperature, and should create litle concerns in offgas handling, execpt for the size of the system.

\section{Plasma Torch Shat Meller}

Being an electrical process rather than a fossil fuel lïed process, the P'TSM produces far less oflgas volumes. Due to the low air rates, particulate entrainment and carryover should be redueced. Plasma systems operating on air have a tendency to produce high levels of NOx, however, other toreh gasses can be used. The very high temperatures of the process have a high tendency to volatilize heavy metals. Overall, olfgas considerations are moderate.

Graphite Electrode Shalt Melter

The situation for the GESM is similar to that of the P'TSM.

Joule-Ileated Melter

Because electrical energy provides the melt heat rather than direct combustion heating, the quantity of the oflgats is redueed and the quality is improved. The particulate load and the amount of gas 10 be treated is minimized, resulting in good contamination control and minimal oflgats requirements. Lower operating temperatures lead to lower NOx generation and lower tendency to volatilize heavy metals.

Microwave Melter

Because electromagnetic energy provides the heat lor vitrification, the quantity of offigas very is low and particulate carryover is minimized. The technolegy operates in a glovebox, providing complete sealing. NOx is not a concern, especially il nitrogen is excluded. Relatively lower cemperatures minimize the potential volatilization of metals. 
Mollen Motill Ballh

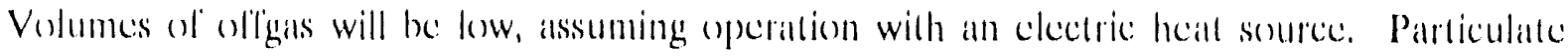
control should be goed based on under melt leeding of material. Metals volatilization will be a concern, as will NOx, based on the high temperature operalion.

Cyclone Mcller

Due to the elficiency of mixing and lurbulenes, the cyclone melter reguires smaller quantitiess of excess air, but due to being a lossil lueled process, is much higher compared to olher melters. The high lurbulenes and small leed malerial siee required will lead lo particulate lormation and contranment. The relatively higher process zone lemperaltures will creale some concerns in the formation of $\mathrm{NO} x$ and the volatilization of heavy metals.

Slagging Kiln

The slagging kiln will require fuel feed to creale the high temperatures, generating relatively high volumes ol'olligas. This results in relatively higher particulate generation and carryover than for other melters. The offgas trealment requirement of the slagging kiln is given a moderate because of the high temperature gas handling requirement, requiring special materials, consideration for metal volatilization and NOx gencration.

Summary of Elfluent Seoring

\begin{tabular}{|l|c|c|c|c|c|}
\cline { 2 - 5 } \multicolumn{1}{c|}{} & \multicolumn{4}{c|}{ Criteria Scores } & Total \\
\cline { 2 - 5 } \multicolumn{1}{c|}{} & $\begin{array}{c}\text { Vol } \\
(1,2)\end{array}$ & $\begin{array}{c}\text { Part } \\
(0,1)\end{array}$ & $\begin{array}{c}\text { Metals } \\
(0,1)\end{array}$ & $\begin{array}{c}\text { Nox } \\
(0,1)\end{array}$ & $\begin{array}{c}\text { Score } \\
(1,5)\end{array}$ \\
\hline FFHM & 1 & 0 & 1 & 0 & 2 \\
\hline GEHM & 2 & 1 & 0 & 0 & 3 \\
\hline FFSM & 2 & 1 & 0 & 0 & 3 \\
\hline PTSM & 1 & 0 & 1 & 0 & 2 \\
\hline GESM & 2 & 1 & 0 & 0 & 3 \\
\hline JHM & 2 & 1 & 0 & 0 & 3 \\
\hline Slaggin Kiln & 2 & 1 & 1 & 1 & 5 \\
\hline Cyclone Melter & 1 & 0 & 0 & 1 & 2 \\
\hline Molten Metal & 1 & 0 & 1 & 0 & 2 \\
\hline Microwave & 2 & 1 & 0 & 0 & 3 \\
\hline
\end{tabular}




\section{Operational Comsiderutions}

Fossil Fucled Hearth Molter

Complexily: The FIHM will be a relative simple process to operale. Vessed conliguration simple.

Hes: Downgraded on high lemperatures. Pressure sealed vessels will be hard to obtain. Mainlenance: Increased reftactory problems expected.

Throughput: These systems are available to a very large capacity balied on stecl making equipment. Good elficiency in transferring encergy to waste. Extreme high emperature possibility will increase throughpul on a relative basis, but heating of offgas from combustible material processing will rob available heal.

Plasma Torch Hearth Mclter

Complexily: The P'THM will be a moderately complex process. Handling of high temperature molten material a concern. Vessel conliguration simple.

H\&S: Downgraded on high temperatures and high voltages an industrial salcety concern. Water breech lrom torch could lead to problems. Vacuum sealed water cooled vessiels common and a big plus.

Maintentunce: Frequent torch electrode replacement required $(10)$ to 200 hours operating time; modular replacement possible. Increased retractory problems expected.

Throughpua: Plasma systems are available to a moderale size capacity on the order of 6 MW. Good elliciency in translerring encrgy to waste. Extreme high temperature possibility will increase throughpul on a relative basis.

Graphike Eilectrode Hearth Melter

Complexity: The GEHM will be a moderalely complex process. Handling of high temperature molten malerial a concern. Vessel configuration relatively simple. Control of are process diflicult.

H\&S: Downgraded on high temperalures and high voltages an industrial salety concern. pressure sealed vessels can be designed and used, but are usually not.

Maintenance: Frequent toreh electrode replacement required, but nowhere near as often als P'THM. Increased reliaclory problems expected.

Throughput: Very large systems are available. (jocol efliciency in translerring energy (o) waste. Extreme high comperature possibility will increase throughput on a relative basis. 
fossil Fucked Shall Moller

Complexity: The FFSM will be a slightly more complex process 10 operate than a hearth process, due to waste leed process reyuirements, and concern for bridging. Vessel configuration simple.

H\&S: Downgraded on brielging problems. Pressure sealed vessects will be hard lo design.

Maintenance: Bridging will reguire extreme measures lo solve. Mainlenanee of waste feed processing equipment will be necded. Some refractory problems expected.

'Throughpul: Heating of offgas from combustible matcrial processing will rob available heat, lowering throughpul on a relative basis.

Plasma Torch Shalt Mcler

Complexity: The PTSM will be a slightly more complex process to operate than a hearth process, dae 10 waste leed process requirements, and concern lor bridging. Also torch operating lunction adds level of difficulty. Vessel conliguration simple.

HaS: $\quad$ Downgraded on bridging problems. Pressure scaled vessels will be somewhal casier to design. Electricall salety concerns.

Maintenanes: Torch electrodes require frequent replacement. Bridging will require extreme measures to solve. Maintenance of waste feed processing equipment will be necded. Some refractory problems expected.

Throughput: Using electrical heal input, and with utilization of ollgas to heat incoming feed, throughpul should be among the highest.

Graphite Electrode Shalt Melter

Complexity: The GESM will be very similar to the P'ISM to operate and will seore the same.

H\&S: Downgraded on bridging problems. Pressure scaled vessels will somewhat casier 10 design. Electrical safely concerns are present.

Matintenance: Torch electrodes require less lrequent replacement than PTSM. Bridging problems will require extreme measures (o) solve. Maintenance ol waste feed processing equipment will be needed. Some refractory problems expected.

Throughpoul: Using electrical heat inpul, and with utilization of ofl'gats to heat incoming feed, throughput should be among the highest.

Jouke-Healled Mcler

Complexily Relatively simple system; downgraded for handling of high temperature molten material. Chemistry eontrol to keep hath molten will require allention. Presence of bulk metal could be a problem. Simple system lo operate, thermally very stable.

H\&S Credited lor increased contamination control through low particulate. Possible to make a sealed process. Removing metal from precess could be a problem. 


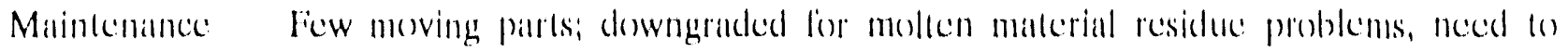
remove motal from bollom of ballh.

Throughpul Overall, throughpul will be lower than oplimum, based an the low process comperaltures achieved, and thus the low healt transler rate to the feed mallerial.

Microwalve Melter

Complexily Relatively simple; sludge predrying is required. Simple device lo operate.

HeS Total glovebox operation is used, providing eprimum contamination control. A plus is that the material is vitrilied in its disposal containes, enhancing contamination control. Molten materials are contained, no handling required; downgraded for uncertainty of electromagnetic energy leakage

Maintenance Downgraded for lack of available information. Microwave generators are known to fail lairly ollen.

Throughput Will be among the lowest in throughpul. Very small size equipment available. Done a drum al a time.

Mollen Melal Bath

Complexity Moderalely simple process to operate, seores the same as are mellers. Simple device lo operale.

HeS Same heallh and saldety concerns as are mellers. Adeled cencern for the introduction of water to the molten metal pool, possible steam explosion.

Maintenance Again similar to hearth are processises.

'Throughput Will be among the highest in throughput, having any one of many heal inpul devices possible.

Cycione Meller

(emplexily: The process is relatively simple to operale since product is air eonveyed and no moving parts are needed. Extensive beed preparation; hewever, adds some complexily. Preparing and foeding glass forming additives ands lo complexity.

HeS: Process operales as a sealed vessed. Provides lon vitrilieation/agghemeration of ash. thus minimizes dispersion polential.

Maintenance: Low maintenance deviess even with freguent themal cycling. High temperatture process ene will lead to relatively more frequent refractery wear.

Throughput: Throughpul limited by ash handling capability. Unit capaciries availahle are quite large. In gencral, low throughput potential. 
Slingging kiln

Complexity: Handling of high temperalue mollen material a moderale complexily. Special malcerials recpuired. Maintaining molten slag chemistry a operating concern. Roballing kiln problems sabne as rotary kiln. Oxygen enrichment or preheanted combustion air recpuired for adecpuate operation.

H\&S: Downgraded due lo special high cemperature and mollen material. Slightly increased contamination control of vitrilied ash. Potential lor release on pressure excursion.

Mantenance: Refactory maintenance repuirements will be extreme. Kiln scal maintenance requirements high.

Throughput: High throughput potential, large capacily units.

Summary of Operability Scoring

\begin{tabular}{|l|c|c|c|c|c|}
\cline { 2 - 5 } \multicolumn{1}{c|}{} & \multicolumn{4}{c|}{ Criterla Scores } & Total \\
\cline { 2 - 6 } \multicolumn{1}{c|}{} & $\begin{array}{c}\text { Comp } \\
(1,2)\end{array}$ & $\begin{array}{c}\text { H\&S } \\
(0,1)\end{array}$ & $\begin{array}{c}\text { Main } \\
(0,1)\end{array}$ & $\begin{array}{c}\text { Thru } \\
(0,1)\end{array}$ & $\begin{array}{c}\text { Score } \\
(1,5)\end{array}$ \\
\hline FFHM & 3 & 1 & 1 & 1 & 3 \\
\hline GTHM & 2 & 1 & 0 & 2 & 2.5 \\
\hline FFSM & 2 & 2 & 1 & 2 & 3.5 \\
\hline PTSM & 2 & 1 & 1 & 1 & 2.5 \\
\hline GESM & 1 & 1 & 0 & 2 & 2 \\
\hline JHM & 1 & 2 & 1 & 2 & 3 \\
\hline Slaggin Kiln & 2 & 2 & 1 & 1 & 3 \\
\hline CYClone Melter & 1 & 1 & 1 & 2 & 2.5 \\
\hline Molten Metal & 2 & 2 & 1 & 0 & 2.5 \\
\hline Mlcrowave & 2 & 2 & 0 & 2 & 3 \\
\hline
\end{tabular}


Relulive Coss Souring

\begin{tabular}{|l|c|}
\cline { 2 - 2 } \multicolumn{1}{c|}{} & $\begin{array}{c}\text { Total } \\
\text { Score } \\
(1,5)\end{array}$ \\
\hline PTHM & 5 \\
\hline GEHM & 3 \\
\hline FFSM & 3 \\
\hline PTSM & 3 \\
\hline GESM & 1 \\
\hline JHM & 1 \\
\hline Slaggin K1In & 3 \\
\hline CyClone Melter & 1 \\
\hline Molten Motal & 1 \\
\hline Microwave & 3 \\
\hline
\end{tabular}


Appendix D

Technology Summary Descriptions 
D. 2 


\title{
Appendix D
}

\section{Technology Summary Descriptions}

\author{
Rotary Kiln Incincrator
}

\section{Technology Description}

The rotary kiln is a cylindrical relractory-lined shell mounted on a slight incline. Rotation of the kiln provides for movement of waste through the kiln as well as for enhancement of waste mixing. Rotary kilns normally require a secondary combustion chamber to assure complete destruction of hazardous constituents. The primary chamber functions to pyrolyze or combust solid waste to gases. The gas-phase combustion reaction is completed in the secondary. Both primary and secondary chambers are generally supplied with auxiliary luel systems. An extensive offigas system is generaily required to control the high volume of emissions.

\section{Past/Current Applications}

\section{Advantages}

The most versatile lype of conventional incinerator, it can handle a wide variety of solid and liquid waste types; a wider range of physical waste feed configurations is possible; ash is removed continuously and does not interfere with waste oxidation; can be operated at very high temperatures to handle ditlicult to destroy constituents; good turndown ratio.

\section{Disadvantages}

High capital cost for installation; high particulate loadings are often experienced; drying of some aqueous sludge waste or melting of some solid wastes can result in clinker or ring formation on refrac:ory walls; spherical or cylindrical objects may roll through the kiln before complete combustion; not very thermally efficient, cannot be thermally cycled often (shutdown/startup cycle).

\section{$\underline{\text { Problems }}$}

Maintaining proper seals at both ends of the kiln is a design and operational problem. Large volumes of air required lor combustion give rise to large, costly, and dilficult to operate offigas treatment systems. Offgas systems generate secondary by-product wastes that are often difficult $t^{\prime}$ handle. Offgas systems are not capable of removing $100 \%$ of radioactive constituents, and thus some small amount of discharge is expected. 
Rescarch Noeds

Betler kiln seal design, advanced offgas systems, better stack monitoring and other real-time performance assurance capabilities; control of heavy metal emissions; combustion by-product formation; sub-micron particulate emissions.

Process Data

Slalus: Operational - Conventional

RCRA Handling Code: T07

Thermal Capacity Range: Low: MMBtu/hr

High: $\quad 150 \mathrm{MMBlu} / \mathrm{hr}$

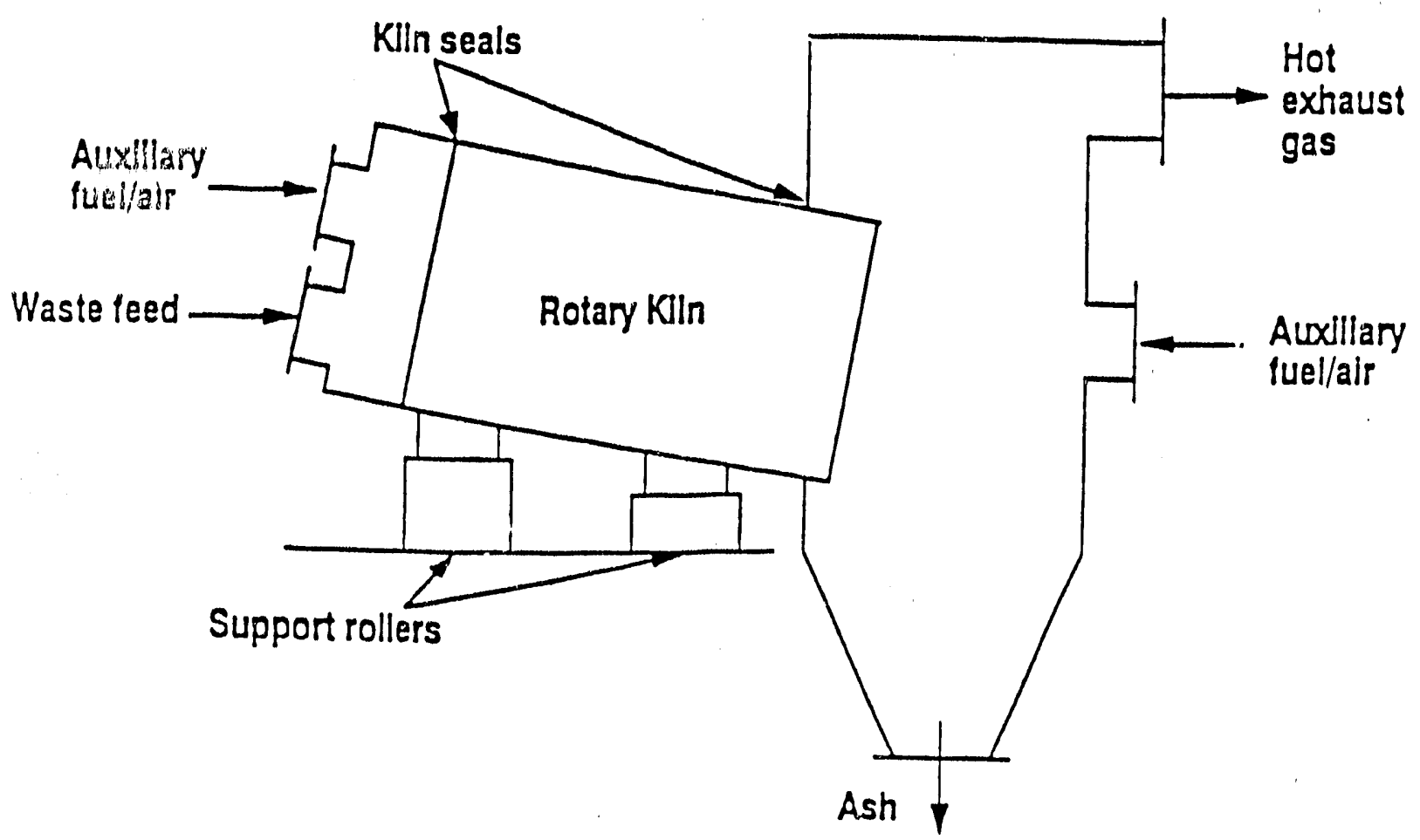

Rotary Kiln Incinerator 


\section{Controlled Air Incinerator}

\section{Technology Description}

A controlled air incinerator is the name often used for the stationary hearth class of incinerator. This type of incinerator is usually designed as a two-stage combustion process with some systems using three chambers. Solid waste is fed into the primary chamber and burned at roughly 50 to $80 \%$ of the stoichiometric air requirement (starved air condition). This pyrolizes the waste, thus emitting a volatile fraction with the required heat supplied by partial combustion and oxidation of the fixed carbon. The resultant smoke and pyrolytic products, consisting primarily of volatile hydrocarbons and carbon monoxide along with some combustion products, pass to the secondary chamber. Excess air is provided in the secondary chamber to assure complete combustion. Liquid waste can be incincrated in either the primary or secondary chambers. An offgas treatment system is required to provide emission control, dependent on the application and waste type.

\section{Past/Current Applicalions}

\section{Advantages}

The starved air condition in the primary chamber leads to a lower air velocity thus minimizing particulate entrainment and carryover; can be used to process a wide variety of wastes including solids, liquids, and sludges; can utilize a wide range of supplementary fuels; can handle wastes with high water content; low cost modular design; easy to control.

\section{Disadvantages}

Solid wastes gencrally have to be pre-treated or packaged in some fashion before they can be fed to the incincrator; not well suited for wastes containing fusible ash, large bulky solid wastes, or large quantities of essentially non-combustible materials (i.c. metal and glass); batch feeding of waste can lead to pressure spikes in the primary chamber.

\section{Problems}

Large volumes of air required for combustion give rise to large, costly, and difficult to operate offgas treatment systems. Offgas systems generate secondary byproduct wastes that are often diflicult (0) handle. Offgas systems are not capable of removing $100 \%$ of radioactive constituents, and thus some small amount of discharge is expected. 


\section{Rescarch Necds}

Advaneed offgas systems, better stack monitoring and other real-time pertormance assurance capabilitics; control of heavy metal emissions; combustion by-product formation; sub-micron particulate emissions.

\section{Process Data}

Status: Operational - Conventional

RCRA Handling Code: T18

Thermal Capacity Range: Low: $0.1 \mathrm{MMBtu} / \mathrm{hr}$

High: $\quad 50 \mathrm{MMBtu} / \mathrm{hr}$

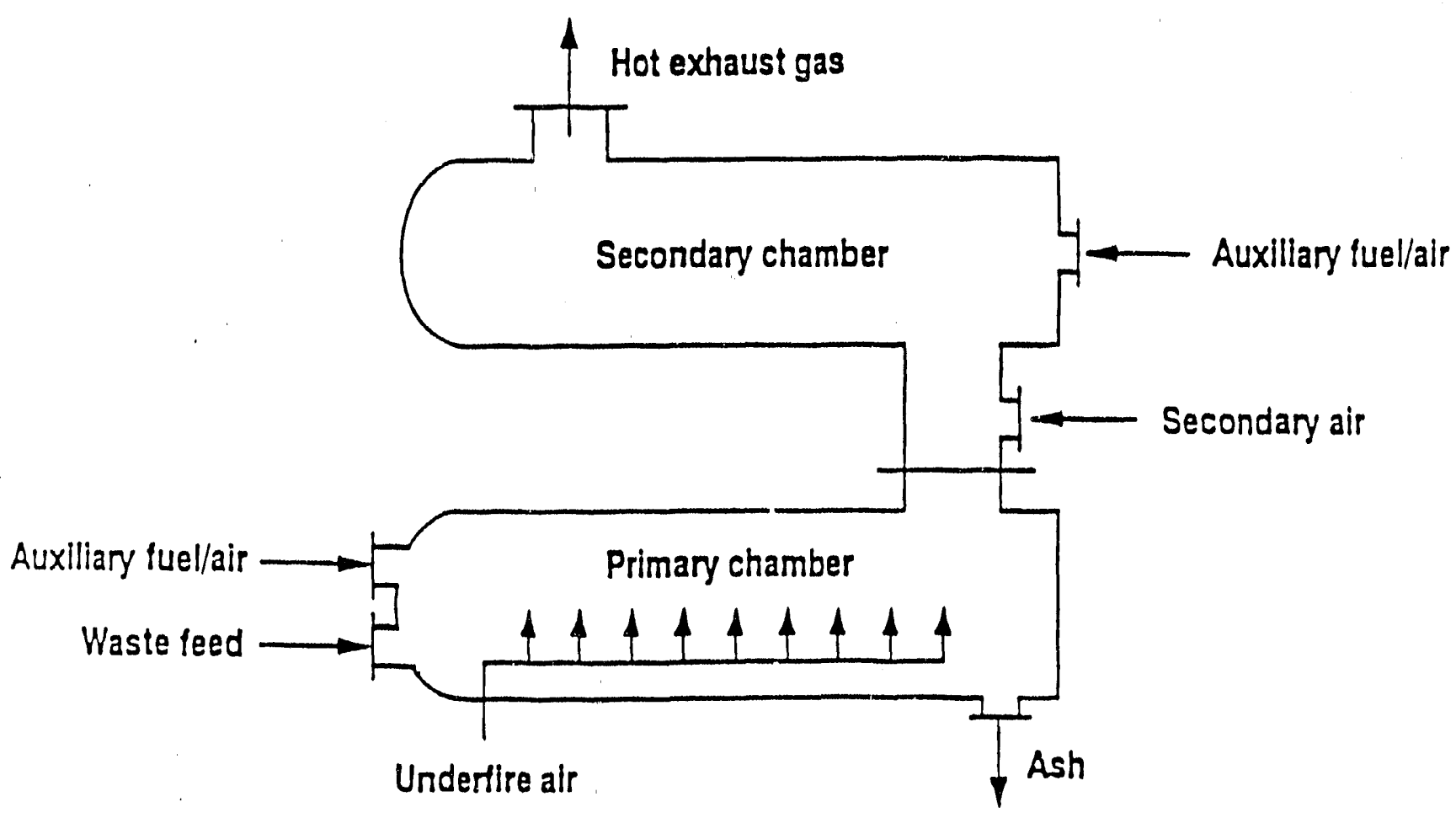

Controlled Air Incincrator

D-6 


\section{Fludized Bed Incincrator}

\section{Technology Description}

A vertical refracting fincd vessel containing a bed of an inert granular material. The bed is "fluidized" by passirie aim, which serves as combustion air, through a perforated plate at the bottom of the vessel. Waste is fed to the hot bed for combustion where the high thermal mass and turbulent mixing action of the bed material rapidly transfers the heal to the waste. Auxiliary fuel is often used to maintain bed temperature. A secondary chamber may be required to ensurs complete combustion for hazardous wastes. Limestone is usually added to the bed to provide capability for in-bed acid gas scrubbing capability (no scrubber required). Offgas particulate removal is required. A variation of lluidized bed technology is a circulating bed system where higher air velocities cause high carryover rates. The earryover material is recovered and returned to the system.

\section{Past/Current Applications}

\section{Advantinges}

Relatively simple design (few moving parts); relatively lower capital and mainlenance eosts; long incincrator life; simplicity of operation; ease of process control; high thermal efficiency; lower operating lemperatures leading to lower $\mathrm{NO}_{\mathrm{x}}$ formation and metal emission rates; capability for in-bed scrubbing (eliminates the need for an offigas scrubber system); versatility (can aceept solids, liquids, sludges, and gases).

\section{Disadvanlages}

Relatively low throughput capacity; difficulty in removing residuals from the bed; high operating costs; solids will likely have to be pre-treated prior to introduction (shredded or sized); non-uniform residenec times; high particulate entrainment rates.

\section{Problems}

Erosion of vessel and related components; oflgas systems are not capable of removing $10(0) \%$ of radicactive constituents, thus some small amount of discharge is expected; low melling point malcrials in the bed may cause the bed to luse. 


\section{Resciarch Necds}

Advanced oftgas systems, better stack monitoring and other real-time performance assurance capabilitics; control of heavy melal emissions; combustion by-product formation; sub-micron particulate emissions.

\section{Process Dala}

Stalus: Operational-Conventional

RCRA Handling Code: T()8

Thermal Capacity Range: Low: $\quad 0.1 \mathrm{MMBtu} / \mathrm{hr}$

High: $70 \mathrm{MMBtu} / \mathrm{hr}$

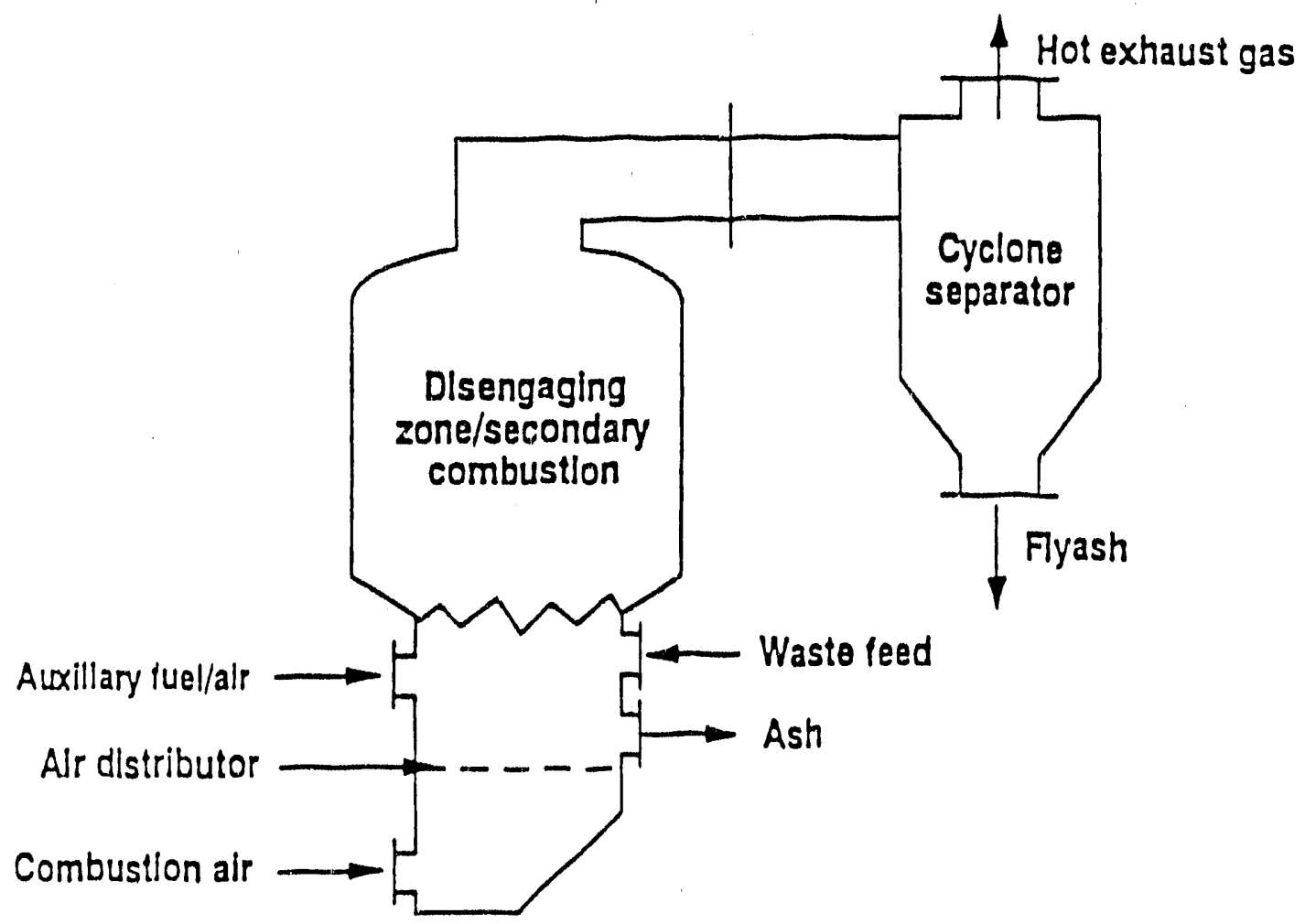

Fluidized Bed Incincrator

D-8 
Molten Salt Furnace ${ }^{a}$

\section{Technology Description}

In the molten salt (MS) process, waste and air are continuously introduced bencath the surface of a sodium carbonate $\left(\mathrm{Na}_{2} \mathrm{CO}_{3}\right)$ melt at a temperature of $750^{\circ}$ to $100\left(0^{\circ} \mathrm{C}\right.$. Supplemental fuel may be required if the waste is not sulficiently combustible. Rapid destruction of the waste results from the catalytic effect of the salt, and from the intimate contact of the waste with air and the hot molten salt, which provides rapid transfer of heat to the waste. The molten salt forms chemical complexes with toxic metals and radionuclides which reduces their thermodynamic activity and thus retains them in the salt. Sodium carbonate is used because it prevents emission of acidic gasses, such as $\mathrm{HCl}$ (ordinarily produced from organic chloride compounds) and $\mathrm{SO}_{2}$ (from organic sulfur compounds). Also, it is stable, nonvolatile, inexpensive, and nontoxic. The carbon and hydrogen of the waste are converted to $\mathrm{CO}_{2}$ and steam; halogens form their corresponding sodium halide salts; phosphorus, sulfur, arsenic, and silicon (from glass or ash in waste) form oxygenated salts; and the iron from metal containers forms iron oxide. The ash is trapped in the melt. The melt is removed periodically or batch-wise to prevent excessive build-up of halide salts or ash. If required, the melt can be immobilized prior to disposal in the appropriate burial facility. Molten salt produces clean gases which are released to the atmosp. are, and spent salt. Spent salt can be disposed of without treatment, immobilized in eement or glass, or processed for metals recovery.

\section{Past/Current Applications}

\section{Advanlages}

High waste destruction efficiency, high heat transfer rates; no liquid waste effluent; combustor is versatile, handling a wide variety of wastes; excellent temperature control due to thermal inertia of melt bed; no production or emission of acid gases; radioactive elements of heavy metals retained in salt.

\section{Disadvantages}

High ash waste requires greater salt make-up than liquid wastes (e.g. solvents); restricted to low-ash, low-water content wastes; feedstock must be size-reduced (will not accept large forms, e.g. 55 gal drum).

a. Cay, Richard L., Contact, Rocketdyne Division, Rockwell International Corp., 66333 Canoga Ave., Canoga Park, CA 91303, (818) 70()-3505. 


\section{Problems}

Special feed preparation and handling required for ecetain waste forms; material eompatibility problems maly result from some wastes; molten salt is corrosive to most metals.

\section{Rescarch Needs}

Performance of materials of construction over rang of salt chemical compositions and temperatures. Develop process lor treatment of spent melt, e.g. process to separate ash from salt; develop process $t$ (o recover radioactive elements or heavy metals from salt.

\section{Process Data}

Stalus: Emerging-Pilot/Emerging-Demonstration

RCRA Handling Code: T11

Thermal Capacity Range: $\quad$ Low: $\quad 0.2 \mathrm{MMB}$ (u/hr

High: $\quad 16 \mathrm{MMBtu} / \mathrm{hr}$

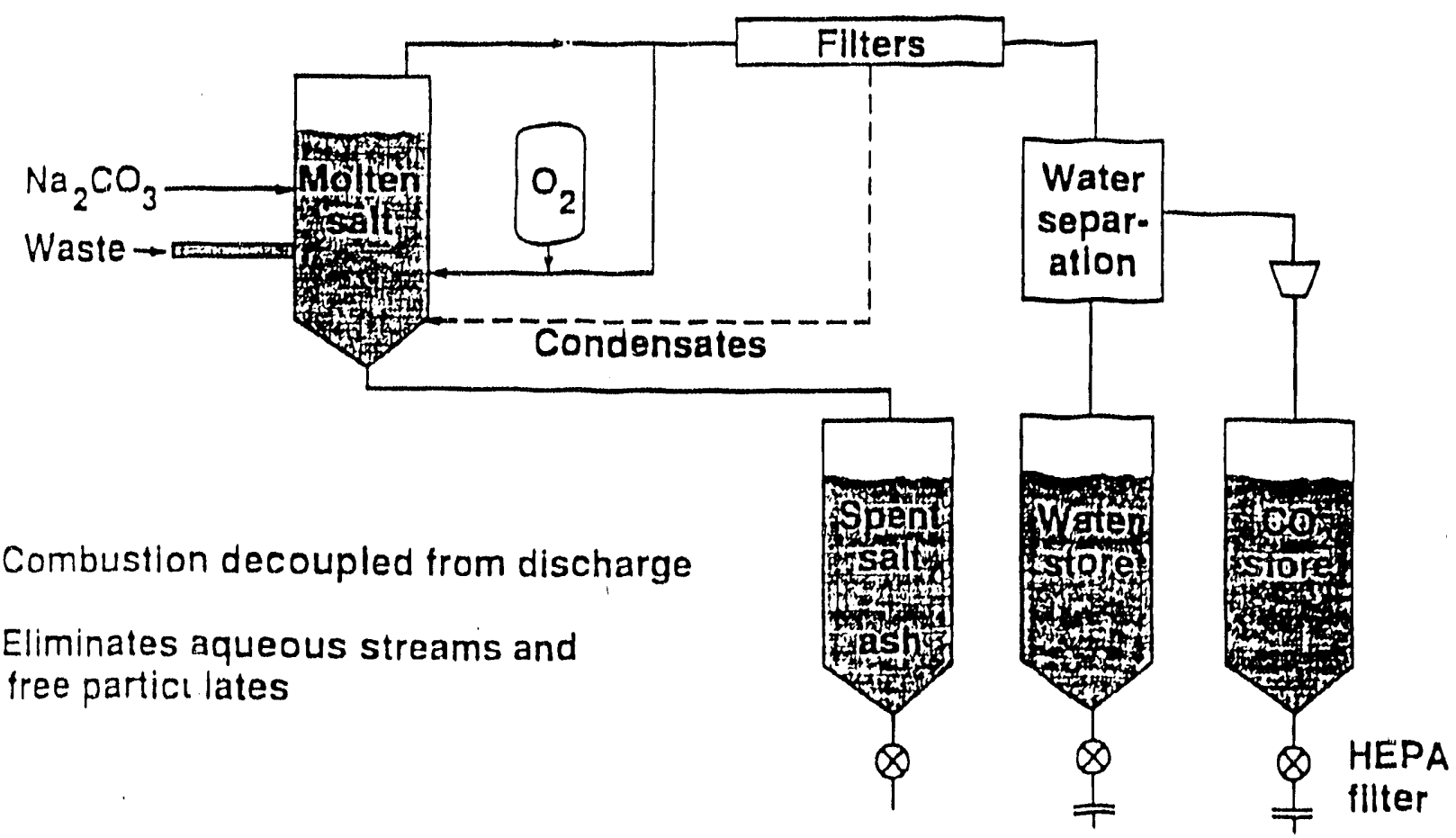

Molten Salt Furnace 
Cyclone Incincrallor

\section{'Lochnology Description}

The cyclene incincralor is a single hearth, vertical cylindrical vessel that by the langential introduction of fuel and air, cyclonic flow is induced. The high-shear cyclonic flow provides intense mixing and complete eombustion. Cyclonic incincrations are primarily used for shedeses, bul special lumaces have also been designed for gases or liguids. Typically, the hearth rotates with stationary rabble lecth for moving ash 10 a center discharge. Hertizontal cyclone furmaces without hearths are: also employed. These units carry the ash away with the offigas for downstream eollection.

\section{Past/Current Applicalions}

\section{Advinnlinges}

Stable and efficient combustion, small combustion volume, high energy density, centrifugal separation of oflgas and particulate loading, long refiactory life, low temperature requirements, last startup and cool down, inexpensive, mechanically simple.

Disarlvanlingess

Limiled (o) giseous, liquid, and sludge wastes.

\section{Problems}

Nonc identified.

\section{Rescarch Needs}

Destruction and removal elficiency determination.

\section{Process Dalla}

Stalus: Operalional-Unique

RCRA Hanciling Code: T18

Thermal Capacily Range: Low: $1 \mathrm{MMB}$ L/hr

High: 150 $\mathrm{MMBlu} / \mathrm{hr}$ 


\section{Resciach Nouds}

Aclvanced oflgas systems; better stack monitoring and other real-time performance assurance capabilitics; control of heavy metal emissions; combustion by-product formation; sub-micron particulate cmissions.

\section{Process Dala}

Status: Operational-Conventional

RC.RA Handling Code: T(o)

Thermal Capacity Range: Low: $1 \mathrm{MMBlu} / \mathrm{hr}$

High: 50 MMBtu/hr

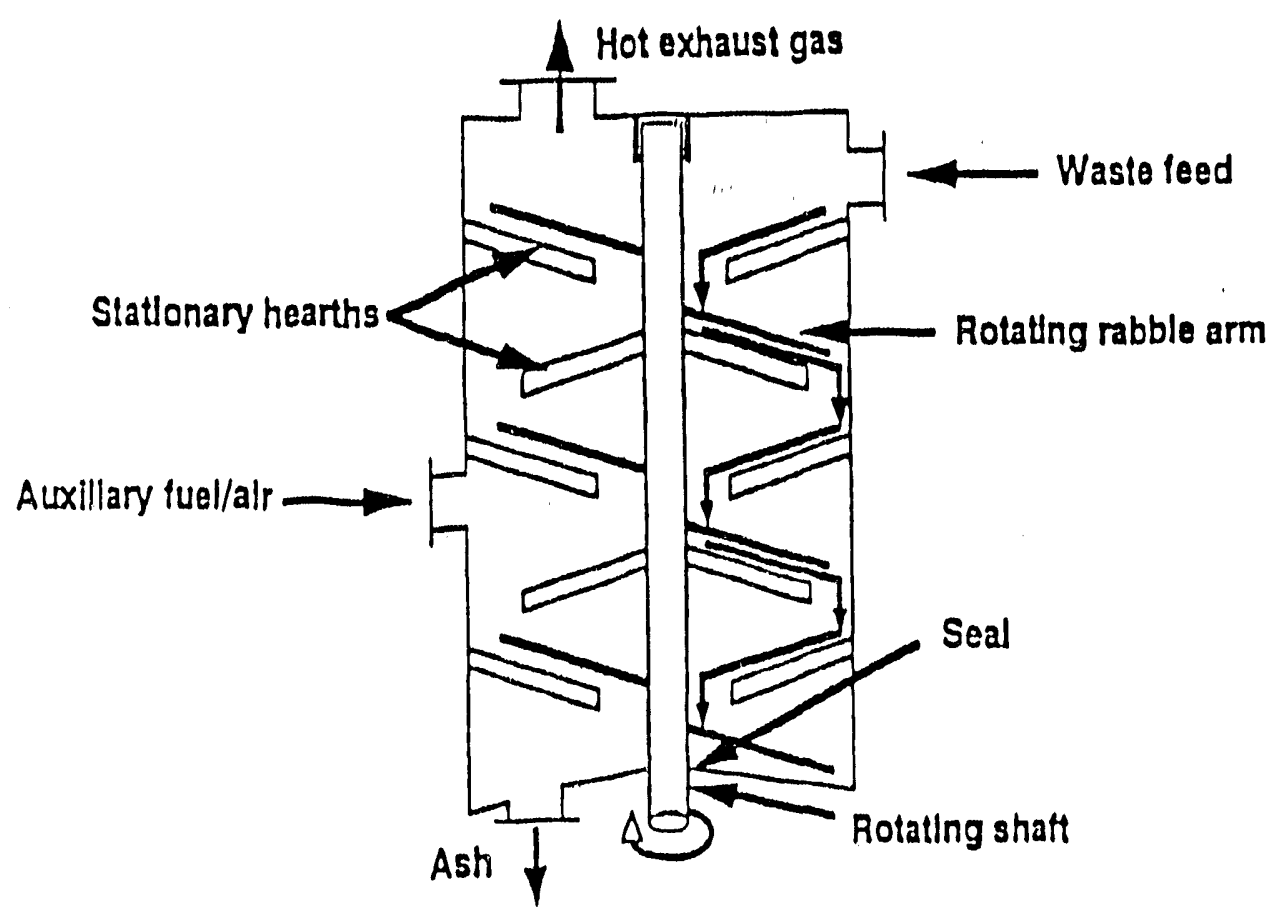

Multiple-Hearth Incinerator

D-12 


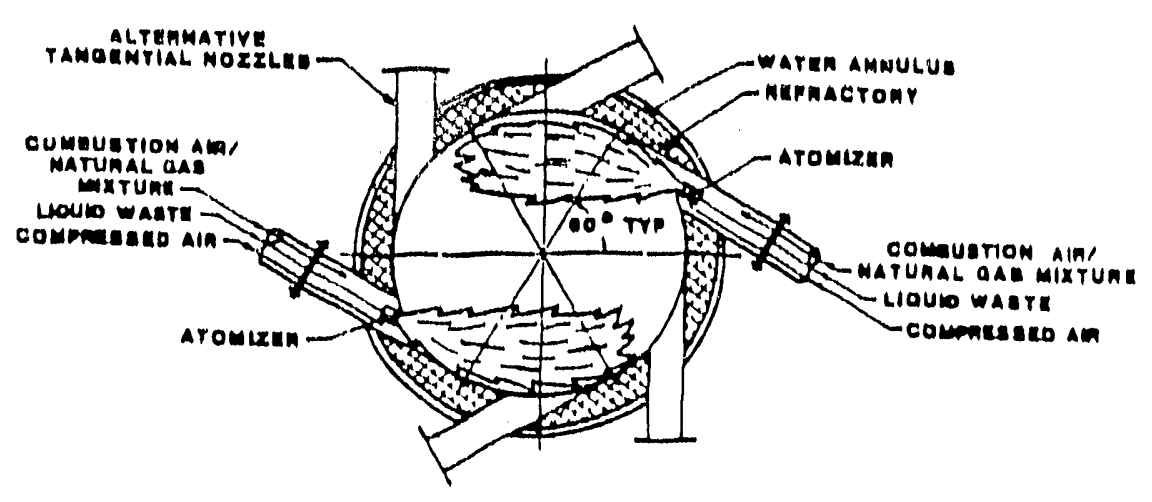

Cyclone Incincrator

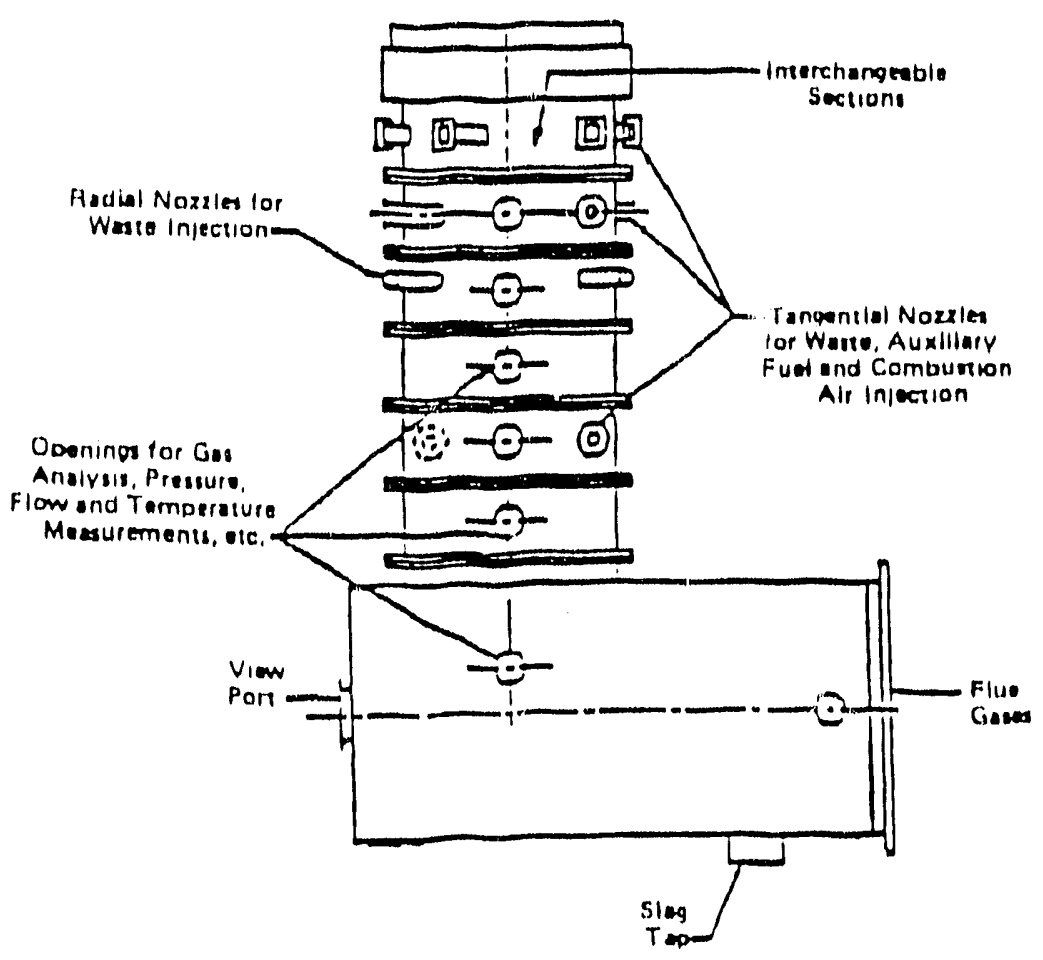

Cyclone Incincrabler Burner Cross Section 


\section{Multiple-Hearth Incincrator}

\section{Tochnolugy Description}

A multiple-hearth incineralor consists of a relrachory-lined sled shell with a series of circular hearths arranged in a vertical design. A scrics of rotating, air-eosled rabble arms conveys the solid waske from upper to lower hearlhs. As the waste is conveyed down through the incinerator the successive hearthe are used for drying, heating, combustion, burnoul, and eooling of the waste. Fuel burners are mounced on the side of the vessel in the hearths where combustion and burnout oceur. These burners can be used for high heal value hazardous liquids if desired. A secondary chamber may be reguired for complete destruction of hazardous wastes. Some form of air pollution control equipment will be required, and will vary with the waste being processed. This type of incinerator has been used principally lor sludges, tars, or other low-heal value solids requiring long solids relention times, and has been commonly used for disposal of de-watered activated waste-water treatment sludges. Use of this type of incinerator has been largely abandoned.

\section{Pass/Current Applications}

\section{Advinlanges}

Long solids retention times; ability to handle a wide range of wastes, including solids, sludges, liquicks, and gases; ability to evaporate large amounts of water; ability to utilize a wide range of fuels.

\section{Disadvantiages}

Inability to handle wastes that fuse into large chunks during incincration; high maintenance costs; nol good for wastes requiring high destruction temperatures; susceptibility to thermal shock; solid wastes may have to be pre-trealed (shredded) before processing.

\section{Problems}

Large volumes of air recquired for combustion give rise to large, costly, and difficult-to-operate offgas treatment systems. Offgas systems generate secondary byproduct wastes that are often difficult to handle. Offgas systems are not capable of removing $100 \%$ of radioactive constituents, and thus some small amount of discharge is expected. 


\section{Slagging Kiln Incincrulor}

\section{Technology Descriplion}

A slagging kiln is an incinerator designed to operate al sulliciently high temperatures so that the entire charge of waske malcrial cissentially melts into a "slag". Almost all slagging kilns are based on an impreved rotary kiln incinerater design (sec "Rotary Kiln" entry for details), requiring more attention to the refractory lining and the slag handling equipment. Other designs are possible, however, as evideneed in one particular application of a Cerman-designed multi-chamber slagging kiln. Slagging kilns normally recpuire a secondary combustion chamber a assure complete destruction of hazardous constituents. The primury chamber functions to combust solid waste to gatios all comperatures of $20(0)^{\prime \prime}$ to 220$) 0^{\circ} \mathrm{F}$, thus leaving a molted slag residue of the noncombustible components (i.e. alumina and silica compounds, metal, glass). The slag melt progresses through the kiln into a waler quench, where it solidifies and tractures into small pieces, and is then drawn from the process. Both primary and secondary chambers are generally supplied with auxiliary fuel systems which can be used for liguid waste incineration. An extensive oll'tgas system is generally required o control the high volume of emissions. Slagging kilns are generally used in applications involving high calcrilic value lype wastes.

\section{Pas//Currenl Applicalions}

\section{Advantanges}

Can handle a wide varticty of solicl, liguid and sludge waste types; can aceept whole melal drums of waste without breaching or shredding; slag is removed continuously and does not interfere with waste oxidation; when operaled at very high temperatures leads 10 more eomplete burning and belter destruction of difficult to destroy compounds; reduced ofligas particulate loadting due to adsorption inte the slag; lower execss air requirements.

\section{Disindvinlinges}

High capilat cost for installation; spherical or cylindrical objects may woll through the kiln before complete combustion; need lo replace the reliactory lining more often; higher temperatures increase: probahility of volatizing heavy metals; not elfieient lor low valorific wastes; cannol be thermally cycled olten (shutdown/startup) cycte); foed composition must be tighlly controlled. 


\section{Problems}

Maintaining proper seals at both ends of the kiln is a design and operational problem. Large: volumes of air required for combustion give rise to large, costly, and difficult to operate offgas treatment systems. Offgas systems generate secondary byproduct wastes that are often difficult to handle. Offgas systems are not capable of removing $100 \%$ of radioactive constituents, and thus some small amount of discharge is expected.

\section{Rescarch Needs}

Better kiln seal design, slag chemistry, advanced offgas systems, stack monitoring and other real-time performance assurance capabilities; control of heavy metal emissions; combustion by-product formation; sub-micron particulate emissions.

\section{$\underline{\text { Process Data }}$}

Status: Operational - Unique

RCRA Handling Code: T18

Thermal Capacity Range: Low: $5 \mathrm{MMBtu} / \mathrm{hr}$

High: $150 \mathrm{MMBtu} / \mathrm{hr}$

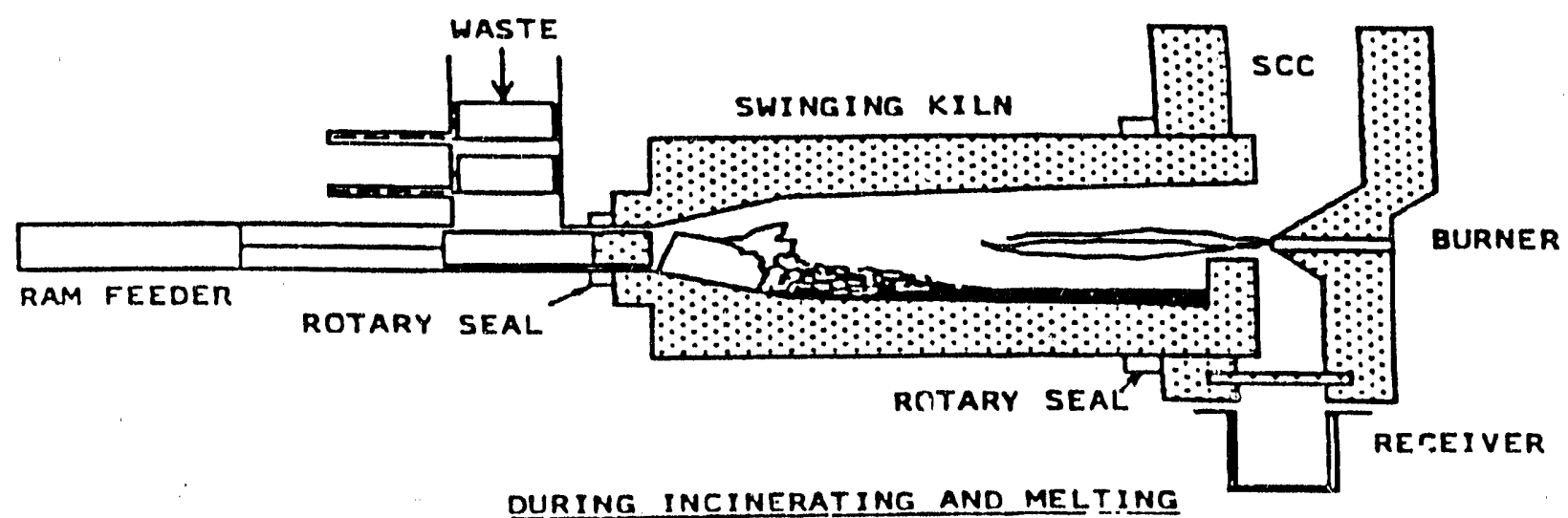




\section{Cyclone Melter}

\section{Technolugy Description}

A cyclone melting system utilizes cyclonic tlow patterns to create high turbulence, which produces good mixing and heat transfer, enhancing combustion of organics and promoting melting, agglomeration, and separation of inorganics. Preheated combustion air $\left(800\right.$ to $1100^{\circ} \mathrm{F}$ ), fucl (natural gas, fuel oil, or powdered coal) and the waste is injected tangentially into a cyclone barrel. Temperatures within the combustion chamber can reach $30(0) 0^{\circ} \mathrm{F}$. At this operating temperature the inorganic components of the feed material are melted and transported to the outer wail of the cylinder. The slag formed is tapped irom the bottom of the chamber and quenched in a water bath. The resulting residue composition and quality is dependent on the waste feed composition and the addition of any glass making constituents. The organics are oxidized either within the primary chamber or in a secondary chamber with a separate burner.

\section{$\underline{\text { Past/Current Applications }}$}

Original development eentered around the combustion of crushed coal in electrical generating facilities. Past vaste applications of the cyclone furnace/melting technology have been for the incineration of sewage sludge, liquid waste destruction, and the combustion of high inorganic (ash) coal. Current applications for incineration/vitrification of municipal solid waste (MSW) ash, incincrator ash, soils with particle size reduction, asbestos, and waste insulation fiberglass are being studied and are in various stages of development.

\section{Advantages}

The Cyclone melter is capable of achieving high destruction and removal efficiencies for organics mainly due to the high turbulenee/mixing of the waste with the fuel/air mixture. This turbulence and mixing also promotes rapid heat transfer, allowing for the melting of inerts ir a short residence time. The resulting slag residue is a glass-like matcrial that should prove leach resistant.

\section{Disadvantages}

Chemistry of the residual solid product is difficult to control due to up-front estimation of waste feed characteristics, prefeeding estimated quantities of chemistry control additives, and short residence time effecting waste mixing and homogeneity. Other disadvantages include: restricted waste feed particle size, little control of late of bulk metals, high temperatures and turbulenee in the system generates thermal NOx, and high temperature also volatilizes some heavy metals(c.g., $\mathrm{Cd}, \mathrm{Pb}, \mathrm{Cr}$ ) which are transported into the off-gas system. 


\section{$\underline{\text { Research Necds }}$}

Research is needed to better define the slag characteristics resulting from the processing of various waste streams. Physical characteristics and chemical leaching characteristics are dependent on the types of waste processed and additives that may be added. Advaneed testing needs to be performed on various anticipated waste compositions.

\section{$\underline{\text { Process Data }}$}

Status: Emorging-pilot

RCRA Handling Code: T18

Thermal Capacity Range: Low: $.70 \mathrm{MMBtu} / \mathrm{hr}$

High: $425 \mathrm{MMBtu} / \mathrm{hr}$

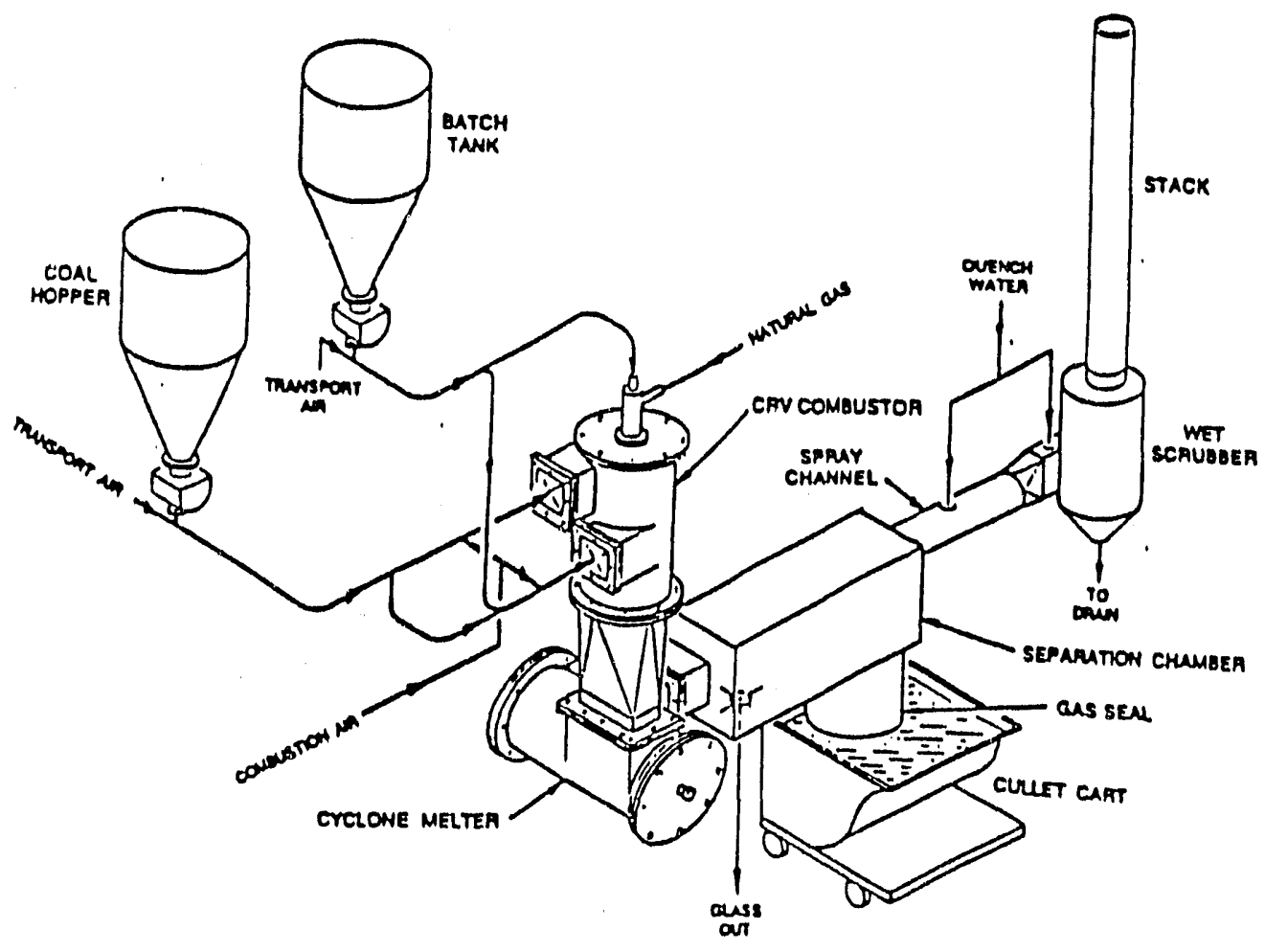

Cyclone Melter 


\section{Technology Description}

A plasma arc furnace uses the energy generated by what is known as a plasma arc "torch" to melt and vitrify inert waste components. The plasma torch is installed into a primary process chamber where the waste materials are fed. Organics present in the feed are processed through a combination of combustion and pyrolysis, depending on the atmosphere maintained in the primary. Pyrolized organics are further treated in a secondary combustion chamber to ensure complete destruction. The remaining inert material is brought to a molten state by the torch. The molten material is discharged from the chamber and forms a leach-resistant, vitrified (glassy) waste form when it cools. Furnace operation is similar to a dual chamber controlled air incinerator, where a plasma arc torch is used in the primary chamber rather than a fuel burner. This configuration allows operation with low primary chamber gas flows and, therefore, low particulate emissions.

One process variation of the plasma torch is called the Plasma Centrifugal Reactor (PCR). The PCR is a (wo-chamber incinerator that operates semi-continuously. Waste matcrial is fed to a rotating primary chamber where rotation of the chamber at $50 \mathrm{rpm}$ forces the molten slag toward the outer walls. After feeding approximately $1000 \mathrm{lbs}$. of inert material, the primary chamber rotation speed is decreased; the molten slag flows to the center of the chamber; the slag pours through a hole in the center of the primary chamber, falls through a secondary chamber, and is collected in a mold below the secondary chamber. Gaseous products are fully combusted in the secondary combustion chamber. The use of an air plasma and pure oxygen for combustion results in very low offgas volumes.

\section{Past/Current Applications}

Plasma arc torches have been used primarily in the metals production industry, particularly in the production of specialty metals, where control of the processing aimosphere is essential. The plasma are torch has been demonstrated as a process for melting and vitrifying incinerator ash, and systems are now being constructed in Japan for this application. Two PCRs have been built, one of which has been demonstrated on a soil matrix, the other on a heterogeneous hazardous waste.

\section{Advantages}

Solid byproduct is a vitrified "glassy" slag that is excellent for stabilization of toxic metals and radionuclides; quiescent combustion in primary chamber results in reduced particulate emissions; plasma energy assists carbon burnout; reduced offgas volume decreases air pollution control equipment costs.

b. Eschenbach, R. C., private communication, June 1990, Retech Inc, Ukiah, CA. 


\section{Disadvantages}

Signilicant electrical energy requirements; operation, start up, and control are more complex than conventional incineration. For the PCR, it is a complex system, with moving parts and rotating seals. The electrode in the plasma torch requires frequent replacement, with current life on the order of $1(0)-200$ hours.

\section{$\underline{\text { Research Needs }}$}

Optimization of slag chemistry for metals stabilization; evaluation of variation in slag chemistry resulting from variations in the input stream; re-introduction of condensed volatile metals into slag phase; clectrode life studies; DRE of hazardous organics.

\section{Process Data}

Status: Emerging-Bench

RCRA Handling Code: T18

Thermal Capacity Range: Low: $100 \mathrm{~kW}$

\section{High: $6 \mathrm{MW}$}

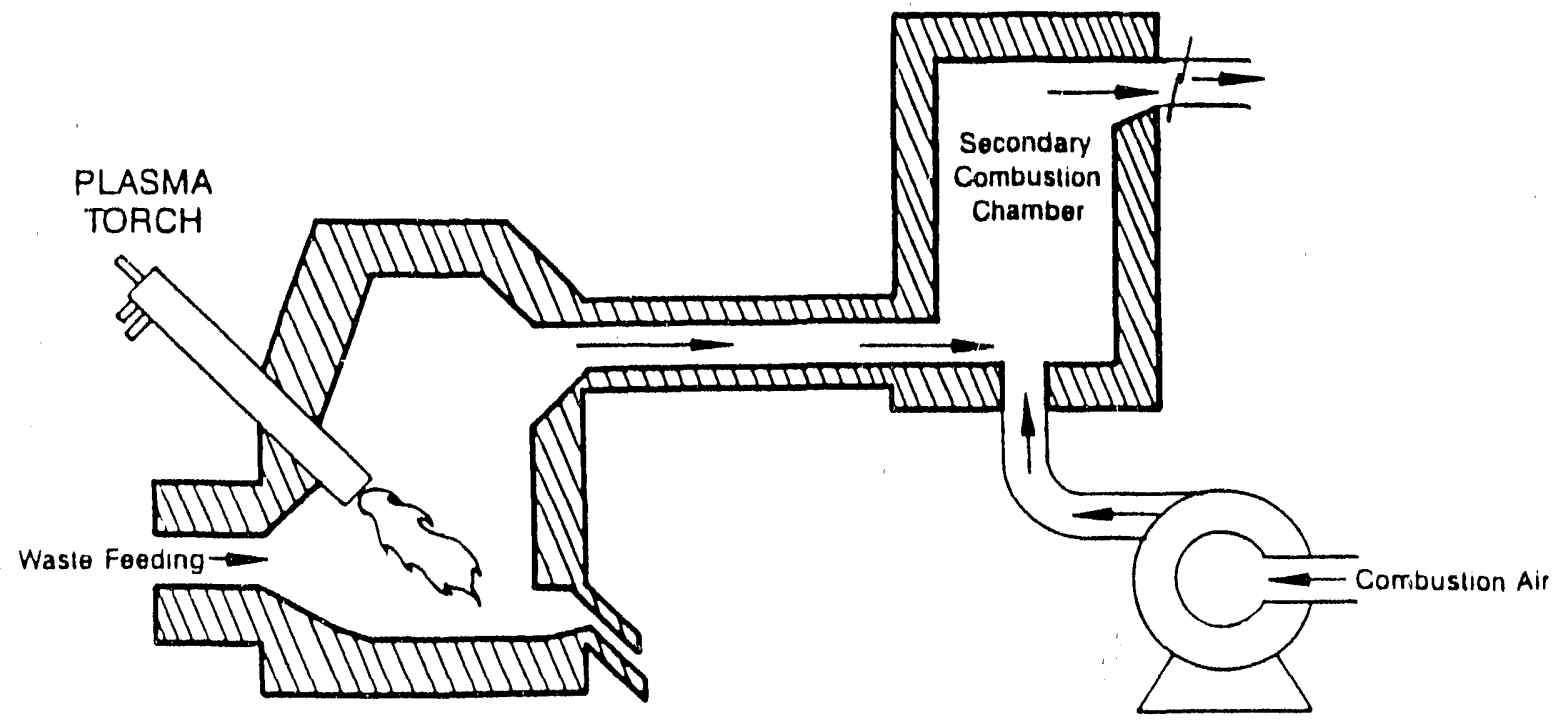

Plasma Torch Hearth Melter

D-20) 


\section{Graphite Electrode Hearth Melter ${ }^{c}$}

\section{Technology Description}

The graphite electrode hearth melter technology encompasses a variety of electrically powered furnaces/melters. These furnaces use electrical energy transferred through graphite electrodes to melt raw materials (ore, slag waste, scrap, etc.) charged into a molten bath. The electrodes may be submerged in the molten bath where the resistance to the electrical current passing between the electrodes creates the temperatures necessary to melt the material, or they may remain above the surface of the bath creating an arc plasma zone of high temperature. Temperatures up to $3000^{\circ} \mathrm{F}$ are routinely maintained within the furnace chamber with even higher temperatures achievable. The high temperatures of the molten bath quickly destroy the organic components while melting the inert material into a glassy slag. A closed-furnace (sealed) system design would provide better offgas contamination control when dealing with radioactive and hazardous waste. Material feed for the closed furnace arrangement can be provided through feed handling chutes, hollow electrodes, or a series of air-lock doors. Material with grain sizes from $1 / 4^{\prime \prime}$ to $2^{\prime \prime}$ diameters can be fed through the chutes while fines $\left(<1 / 4^{\prime \prime}\right)$ can be fed through the electrodes. Larger containers and objects can be fed through the air-lock door system.

\section{Past/Current Applications}

The electric-arc melting technology has been used in the steel industry for many years. Applications have focused on secondary smelting ard metals recovery from steel making dusts and scrap iron. Current steel applications for sealed systems are for pig-iron smelting in a reducing atmosphere. New applications in the waste processing area are being demonstrated. An Arc Pyrolysis unit using a direct current electric arc furnace has been designed specifically for the treatment of solid hazardous waste. Limited data on this process is available at this time.

\section{Advantages}

Electric-arc furnaces can handle a wide variety of waste forms and sizes, depending on whether an open or closed system is used. The use of electrical energy rather than a fossil fuel for melting and combustion of the waste material significantly reduces the volumes of offgas and associated pollution control equipment requirements. Additionally the slag residue produced is a vitrified material that is likely to be a very stable waste form.

c. Cotchen, J. K., private or mmunication, Lectromelt Corporation, Pittsburgh, PA, July 1991. 


\section{Disadvantages}

The high operating temperatures of the system volatilize heavy metals such as cadmium, lead, and chromium. Electrode consumption is high, particularly in an oxidizing environment. The potential for accidental feed of water below the molten surface of the melt could cause a steam explosion. Additionally high turbulence causing offgas control difficulties may result from the introduction of high combustible waste streams.

\section{Research Needs}

Optimization of slag chemistry for heavy metals stabilization; evaluation of variations in slag chemistry resulting from variations in the input waste; reintroduction of condensed volatile metals into the slag phase. Additional testing and evaluation of technology performance on anticipated waste compositions must be performed.

\section{Process Data}

Status: Emerging-pilot scale RCRA Handling Code: T18

Thermal Capacity Range: Low Range: $0.2 \mathrm{MMBtu} / \mathrm{hr}$

High Range: $164 \mathrm{MMBtu} / \mathrm{hr}$

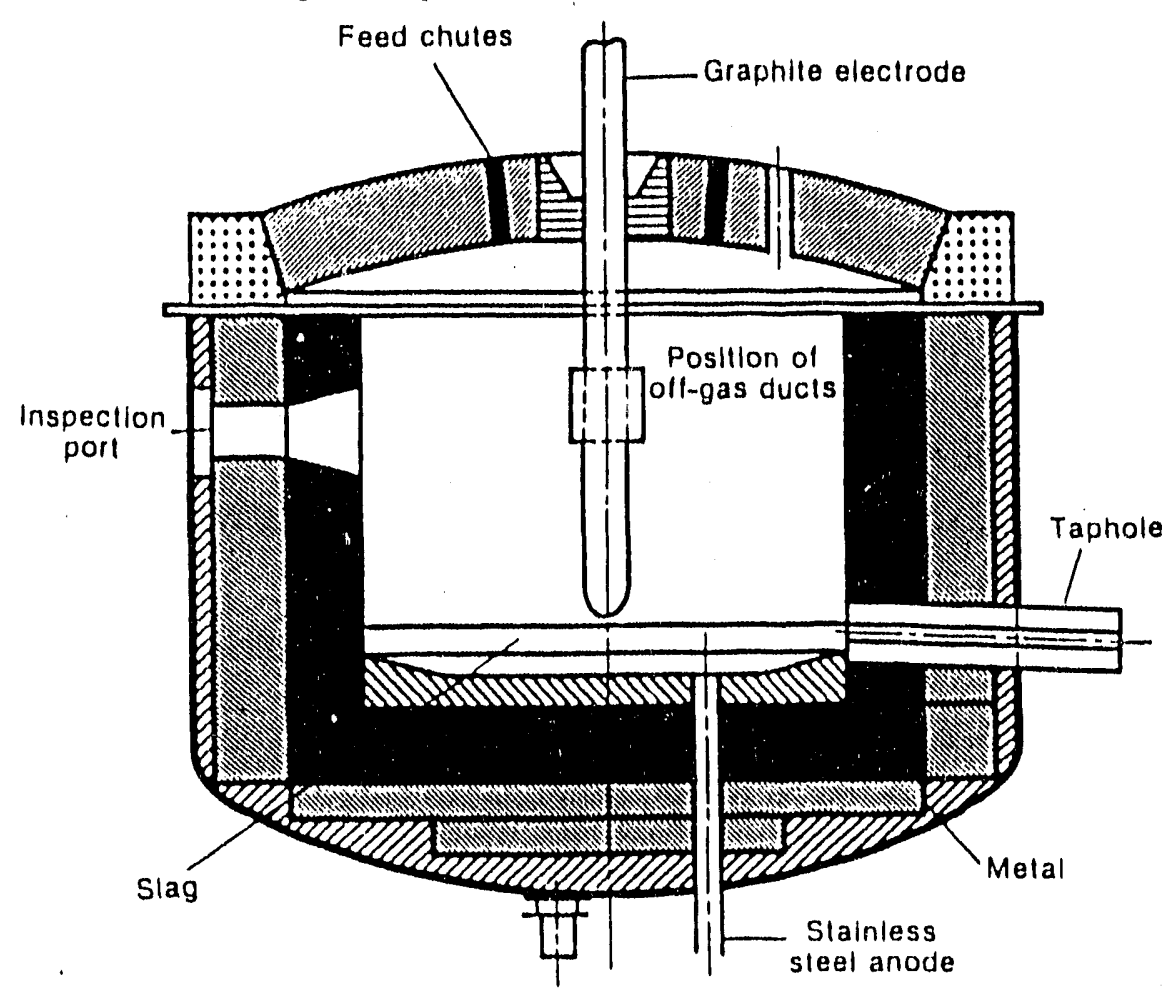

Graphite Electrode Hearth Melter 
Fossil Fucled Shat't Furnace (Cupola)

\section{Technology Description}

The traditional cupola is a vertical cylindrical water-cosled shaft furnace commercially used in the foundry industry. The process feed material, typically consisting of scrap iron and steel along with coke and limestone, is led into the furnace from the top, and the combustion (blast) air is introduced through tuyeres at the base of the vessel. The combustion of the coke and the counter current llow of the product gases through the charge material supply the heat necessary to melt the iron. The cupola furnace is operated in a reducing atmosphere to promote the reduction of metallic oxides associated with the iron scrap charge. The primary product gases are carbon monoxide $(\mathrm{CO})$ and hydrogen $\left(\mathrm{H}_{2}\right)$. Limestone is the primary fluxing agent added to slag the coke ash and other non-combustibles. Metal and slag are tapped from the bottom of the lurnace and the $\mathrm{CO}$ and $\mathrm{H}_{2}$ are led into an air enriched afterburner to complete combustion of the $\mathrm{CO}, \mathrm{H}_{2}$, and any volatiles. Conventional cupola furnaces operate with a metal to coke weight ratio of approximately $10: 1$ with 9()$\%$ of the coke is consumed in heating and $10 \%$ added as carbon to the metal.

Variations of the basic cupola "cold-blast" (no waste heat recovery) furnace have been developed over the years. A hol-blast cupola furnace was developed to recover the sensible heat in the exhaust gases and increase the blast temperatures to

$4(0){ }^{\circ} \mathrm{C}$. Additional developments have entered around the use of auxiliary fuels such as natural gas, oil, anthracite coal and plasma are (electrical) to minimize the quantity of coke needed as well as increase the productivity while decreasing the environmental impact of off gas products.

\section{Past/Current Applications}

The cupola (shaft) furnace is a very mature secondary smelting foundry technology. New areas of application are focusing on the waste treatment potential of these furnaces. With the addition of plasma torches and other auxiliary sourees of heat energy, the cupola furnace may have potential waste processing applications.

\section{Advantages}

Shat furnace smolting is a mature technology and considerable experience in adapting auxiliary heal sources (c.g., plasma are) to enhance system flexibility have been tested and verified in the foundry industry. This experience will influence future development, however the echnology is limited by the lack of development for waste treatment. 


\section{Disadvantages}

Conventional lossil lucl-fired cupola furnaces have significant gas velocilies which prevent the charging of fine material. Fines and small particles are casily entrained and carried into the pollution control equipment. Bridging and freezing of the charge material can occur. Nonhomogeneity of feed material can cause slag chemistry control problems and temperature excursions within the furnace.

\section{Process Data}

Status: Emerging technology

RCRA Handling Code: T18

Thermal Capacity Range: Low: $4 \mathrm{MMBtu} / \mathrm{hr}$

High: $250 \mathrm{MMBtu} / \mathrm{hr}$

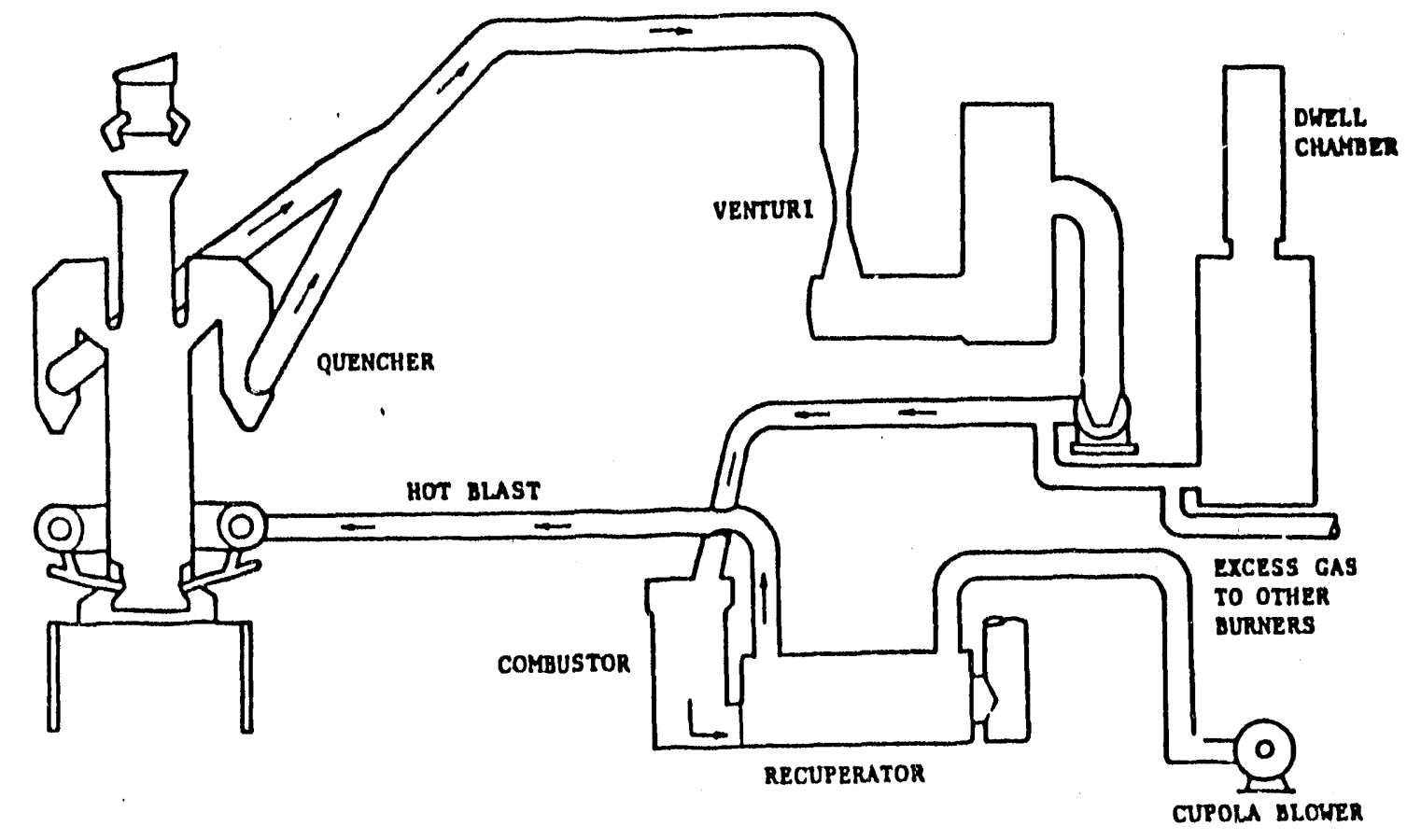

Fossil Fuel Shaft Furnace 


\section{Plasma Torch Fired Shaft Furnace ${ }^{d}$}

\section{Technology Description}

The Plasma-fired cupola operates in much the same way as the conventional fossil fuel-fired cupola except it utilizes plasma torches as an auxiliary source of thermal energy. The plasma torches are symmetrically located at the base of the vessel in the areas of the tuyeres. The plasma torches superheat the blast air up to $1000{ }^{\circ} \mathrm{C}$. This heat source decreases the amount of coke necessary in the feed, which greatly reduces the volume of offgas generation. The decrease in offgas generation reduces the gas velocities within the furnace allowing finer material to be charged and processed. Process gases (e.g., $\mathrm{CO}, \mathrm{H}_{2}$ ) from the top of the furnace are recycled through the plasma torches additionally reducing off'gas volumes. The product gases not recycled are fully oxidized in an air enriched afterburner as in the conventional cupola.

\section{Past/Current Applications}

Plasma-fired cupola furnaces have been commercially applied in the foundry industry. Plants applying this technology both in the U.S. (General Motors) and abroad (Peugeot) have verified the benefits of using plasma are fired cupolas in foundry applications. Westinghouse Electric is presently involved in extending the application of this technology to hazardous waste treatment. Limited information is currently available on the testing of this pilot scale system.

\section{Advantages}

The Plasma-fired cupola has a number of advantages over the conventional coke fired cupola. The reduction of coke use reduces cost, decreases offgas generation and particulate emission by reducing superficial velocities within the furnace. The auxiliary heat source provided by the plasma allows flexibility in waste input characteristics and melt temperatures can be controlled rapidly reducing bridging problems.

\section{Disadvantages}

As with conventional cupola furnaces the "bridging" of the charge material can occur. Residual solid product chemical and physical characteristics is very difficult. Slag chemistry is only controllable based on initial feed characteristics, waste density and waste mixtures. Estimation of feed parameters, fluxing additives, and non-homogeneity of waste will cause final waste form

d. Dighe, S. V., private communication, Westinghouse Electric Corporation, Madison, PA, September 1991. 
variations. Additionally channeling of offgas through the charge material causes variation in bed temperatures and other operational parameters.

\section{Research Needs}

Continued testing and development for waste treatment applications is necessary. Characteristics and mixes of charge material variations and resulting slag chemistry needs further study.

\section{Process Data}

Status: Emerging-bench scale RCRA Handling Code: T18 Thermal Capacity Range: Low: $4 \mathrm{MMBtu} / \mathrm{hr}$

High: $41 \mathrm{MMBtu} / \mathrm{hr}$

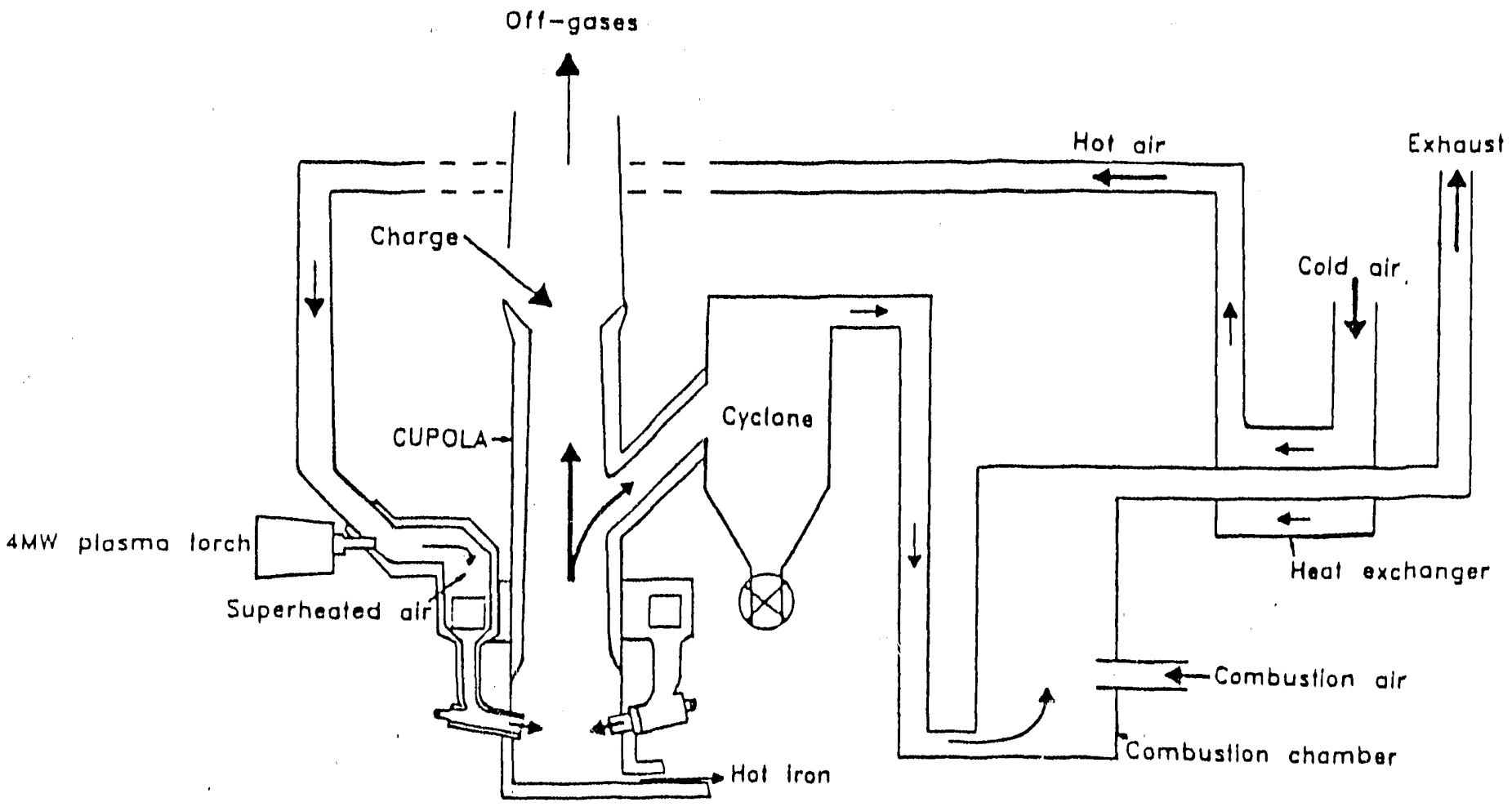




\section{Graphite Electrode Shall Furnace}

\section{Technolugy Description}

The graphite electrode shalt furnace technology focuses around the use of electrical energy rather than fossil fuels, transmitled through an electric are to pyrolyze hydrocarbons into partially oxidized gaseous components $\left(\mathrm{CO}, \mathrm{H}_{2}\right.$, tars,gums, etc) which are subsequently fully oxidized in an air rich afterburner. The pyrolyzing eoneept of incineration utilizes a starved air environment in the primary chamber to obtain the partially oxidized effluent.

A variation to the typical pyrolysis process is known as the Skygas proesss. The skygas process depends on an electric are initiating the dissociation and activation of water within the reactor and the feed to create gaseous radicals of $\mathrm{H}_{2}$ and $\mathrm{OH}$. The gascous radicals pass up through the waste initiating a chain reaction and propagation of additional frec radicals and nonradicals. The large hydrocarbon molecules are thus broken down into partially oxidized gascous components. Predominate gas products from the skygas process are the same as the basic pyrolysis process and consist primarily of $\mathrm{CO}$, and $\mathrm{H}_{2}$.

The gases exiting the primary chamber are again subjected to an electric are and passed through a coke bed for additional refining and breakdown of lars and gums.

\section{Past/Current Applications}

Controlled air pyrolysis using fossil fuels as the heat sourec have been used as a waste treatment process for many years. The use of a controlled air electric are process in a waste treatment application is new. Limited data is currently available on the application of this technology to waste treatment.

\section{Actvantagcis}

The use of an electric are rather then fossil fuels to pyrolyze and/or initiate radical chain reaction chemistry will reduce the offgas volume generation which will reduce pollution control handing requirements. Muitiple sets of reactor units in the skygas process would further reduce carbon dioxide and tars/gums resulting in a higher quality ol gas procluct lor reuse.

\section{Disadvantages}

As with other shaft furnace lechnologies bridging of the charged matcrial within the shaft is a problem, especially if high percentages of low melting materials (c.g. glass) exist within the feed material. The resulting residue from the primary reactor of the SkyGas process is a non-vitrified 
ash. Limited feed handling capabilities were noted in testing of chopped tire feed and high moisture content sludges.

\section{Rescarch Needs}

Limited data exists on the application of this technology on waste streams of mixed composition. Additional testing and documentation of process data, operational parameters and waste acceptability needs to be performed. Final waste form (ash) stabilization not well addressed in the Skygas process.

\section{Process Data}

Status: Emerging technology

RCRA Handling Code: T18

Thermal Capacity Range: Low: $4 \mathrm{MMBtu} / \mathrm{hr}$

High: $41 \mathrm{MMBlu} / \mathrm{hr}$

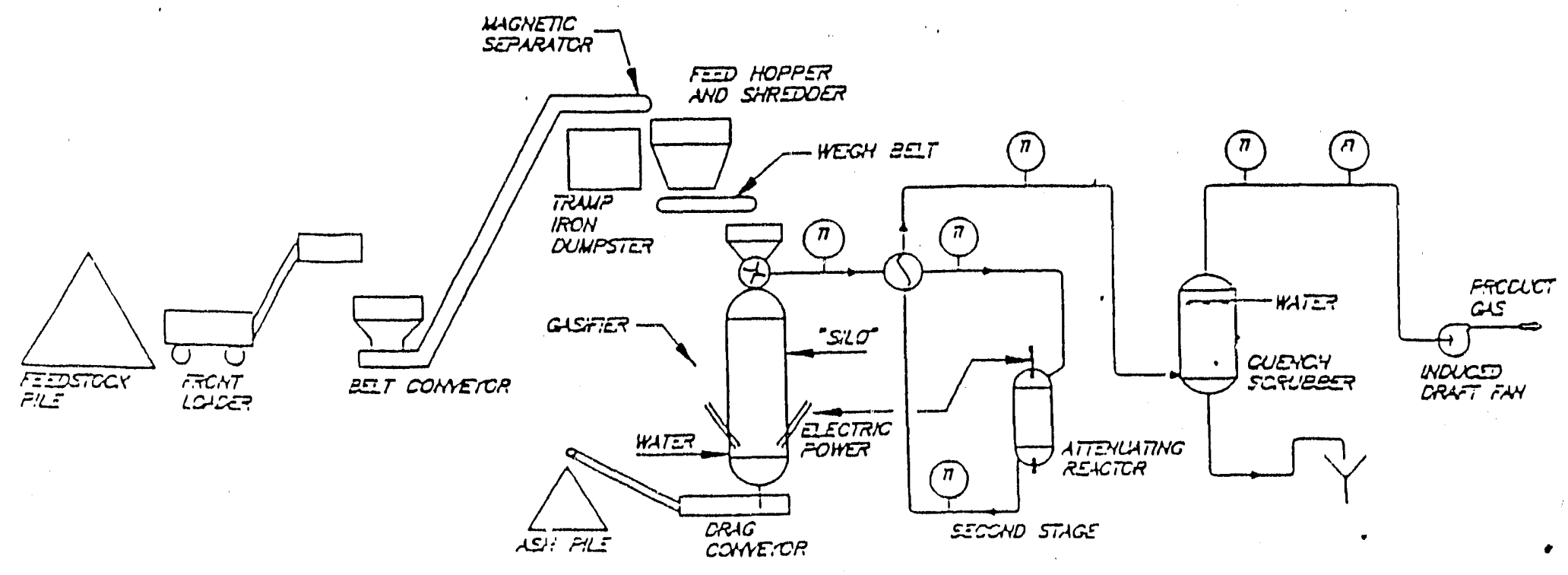

Graphite Electrode Shaft Furnace

D-28 


\section{Joule-Heated Mclter ${ }^{\mathrm{e}}$}

\section{Technology Description}

A refractory lined reactor in which a pool of glass is initially melted by auxiliary heating, then maintained in a molten state $\left(2000^{\circ}-2300^{\circ} \mathrm{F}\right)$ by joule heating (electric current passing through the glass between submerged electrodes). Waste is introduced into one end of the furnace above the molten glass along with combustion air. Combustion is achieved by exposure to the radiant heat above the pool or by contact with the molten pool. Exhaust gases flow out the opposite end of the furnace. Solid products of combustion and noncombistible materials are encapsulated in the glass, which can be continuously removed or batch discharged to solidify into a non-leachable matrix. A feeding variation by one developer introduces the waste and air into the body of the molten glass via a drop tube. This arrangement is intended to confine most of the combustion below the surface of the pool, enhance intermixing of the waste and combustion gases with the glass, and attain higher particulate retention.

\section{Past/Current Applications}

\section{Advantages}

Compatible with most forms of hazardous wastes; high temperatures result in high DRE's; encapsulation of hazardous matcrials in non-leachable glassy matrix; simple and compact design; technology proven for non-waste applications; non-flame combustion climinates fuel-PIC contamination of offgas; offgas treatment residues (filter, ash, scrub liquors) can be disposed of by processing through the melter; high thermal stability provided by molten pool.

\section{Disadvantages}

High moisture content wastes must be pre-treated to minimize moisture; dense solids tend to settle out of the glass; significant waste metal content affects electrode operation; relatively high energy and capital costs; technology unproven for hazardous wastes.

\section{Research Needs}

Demonstrate effectiveness in treating hazardous wastes; investigate partitioning of nuclides and heavy metals in glass.

e. Penberthy, Larry, Contact, Penberthy Elecíromelt International, Inc., 631 S. 96 th St., Seattle, WA 98108, (206) 762-4244. 


\section{Process Data}

Status: Operational-Unique

RCRA Handling Code: T18

Thermal Capacity Range: Low: $1.8 \mathrm{MMBtu} / \mathrm{hr}$

High: $78 \mathrm{MMBtu} / \mathrm{hr}$

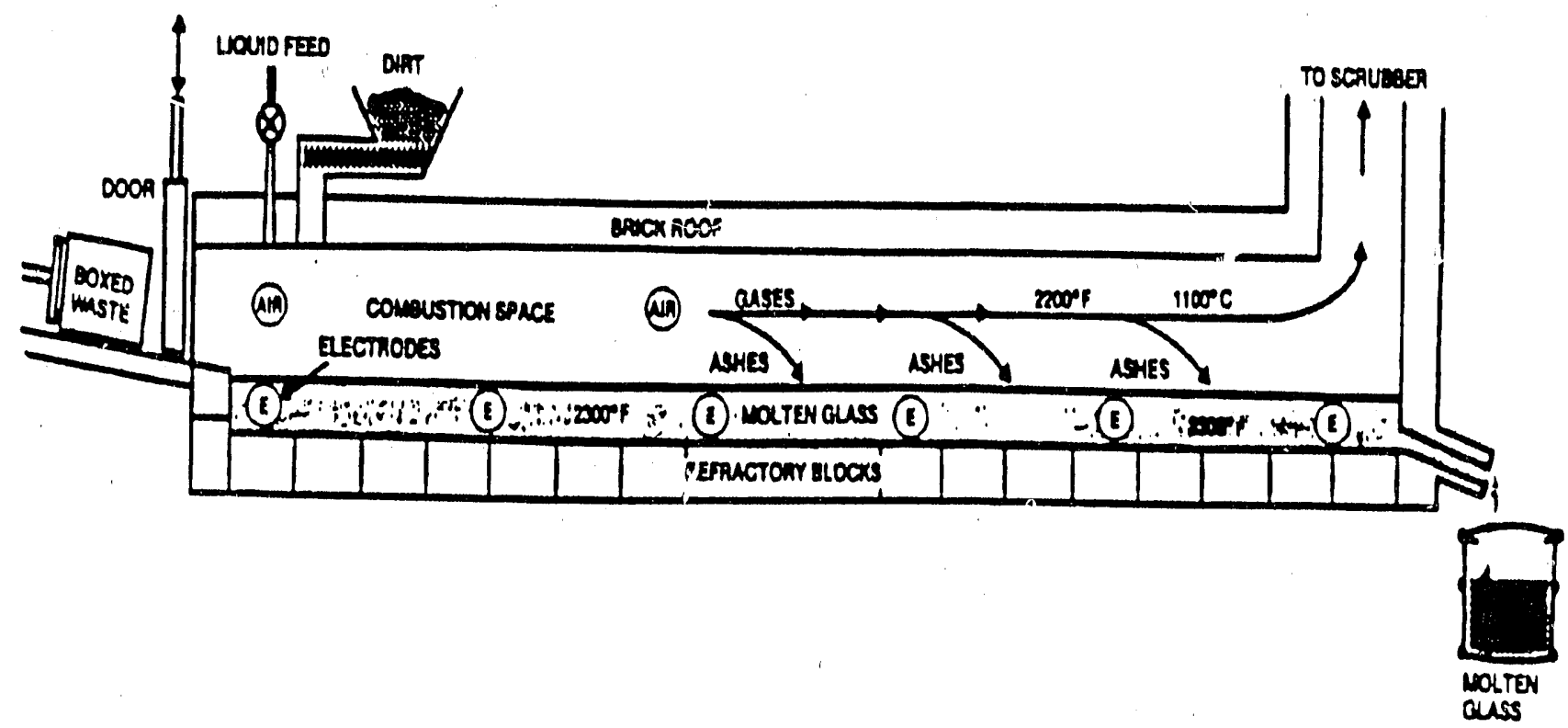

Joule-Heated Melter 


\section{Microwave Melter}

\section{Technology Description}

This process utilizes microwave energy for in-container solidification/stabilization of radioactively contaminated non-organic wastes such as incincrator ash, sludges, or soils. Waste moisture is removed in a belt-driven microwave dryer prior to treatment. The dry waste materials are vitrified inside a metal disposal container in either a batch or continuous feed mode. Melt temperatures range from $1800^{\circ}-2600^{\circ} \mathrm{F}$ and the resulting product is a glassy monolith that meets radi retive disposal criteria for liquid and particulate content, and RCRA LDR requirements for leaching of toxic hazardous constituents. The process results in volume reductions on the order of $80 \%$ with waste loadings on the order of $60 \%$.

\section{Pas/Current Applications}

\section{Advantagres}

Direct application of energy to the wastes - surrounding equipment remains relatively cool; process oceurs inside disposal container, minimizing waste handling.

\section{Disadvantages}

Applicable to dry or near-dry non-organic wastes only; waste must be relatively homogeneous fïncs.

Problemss

Uneven meltirg of the wastes, especially near the bottom and sides; some oxidation of the metal waste container; melt-through of the container at hot spots.

\section{Research Needs}

Evaluation of t.xe process for other applications, i.c. destruction of hazardous wastes; keachability of the vitrified waste. 


\section{Process Dala}

Stalus: Emerging-Pilot

RCRA Handling Code: T18

Thermal Capacity Range: Low: $0.02 \mathrm{MMBtu} / \mathrm{hr}$

High: $0.32 \mathrm{MMBtu} / \mathrm{hr}$

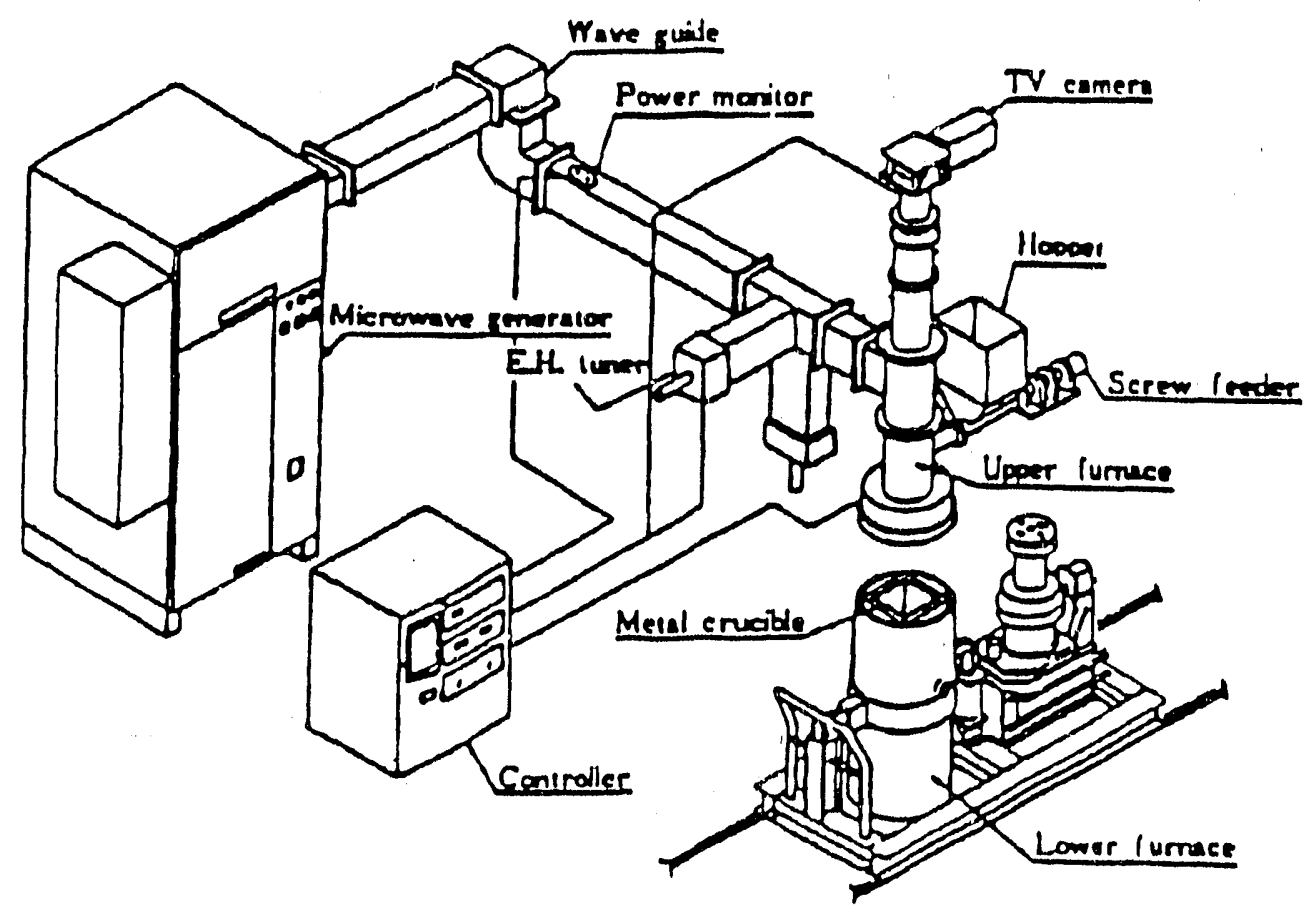

Micron ave Melter 


\section{Molten Metal Bath Technology}

\section{Technology Description}

The molten metal bath technology is a treatment process which utilizes a pool of molten metal as the medium to transfer heat to the waste material. The high temperatures associated with the molten metal destroys the organics and melts the inorganics into a glassy slag matrix. The slag is drawn off the top of the melt and the bath is maintained by tapping off or adding metal as required. As with other melting processes fluxing agents can be introduced to enhance the melting of the waste. Temperatures of the metal bath can range from $2500{ }^{\circ} \mathrm{F}$ to $3500{ }^{\circ} \mathrm{F}$ with $3000^{\circ} \mathrm{F}$ being the typical average. Acceptable waste forms are gases, liquids, sludges, and solids (with size reciuction). Oxygen can be injected into the bath to strip the carbon absorbed by the steel thus forming carbon monoxide. The furnace is operated in a reducing atmosphere to reduce the metal oxides.

\section{Past/Current Applications}

Metal bath processes have been used in the steel making industry for many years. Development of the technology for waste treatment applications is relatively recent. U.S. Steel developed a metal bath technology termed the catalytic extraction process (CEP). Testing has been conducted on organics with metals, municipal waste, sludges, flyash, and other chemical and industrial waste materials.

\section{Advantages}

With the high temperatures in the metal bath and the rapid heat transfer to the introduced waste a high destruction efficiency of organics can be achicved. The final waste form is a vitrified slag that is likely to be highly stable and leach resistant. Operation in a reducing mode minimizes the high thermal $\mathrm{NO}_{x}$ that is normally generated in a high temperature process.

\section{Disadvantages}

Slag chemistry is highiy dependent on waste characteristics and may be difficult to control with non-homogeneous waste inputs. High temperatures result in high volatilization of heavy metals which are carried into the offgas equipment. Introduction of significant quantities of wet solids or non-combustible liquids may cause steam explosion concerns.

f. Metelmann, O., private communication, Mannesmann Demag Corporation, Coraopolis, PA, July 1991. 
Rescarch Needs

Primary research needs are in the areas of partitioning of radionuclides and heavy metals within the bath, variation of slag chemistry resulting from variations in waste composition, and continued demonstration of effective hazardous waste destruction.

\section{Process Data}

Status: Emerging pilot

RC.RA Handling Code: T18

Thermal Capacity Range: Low:

High:

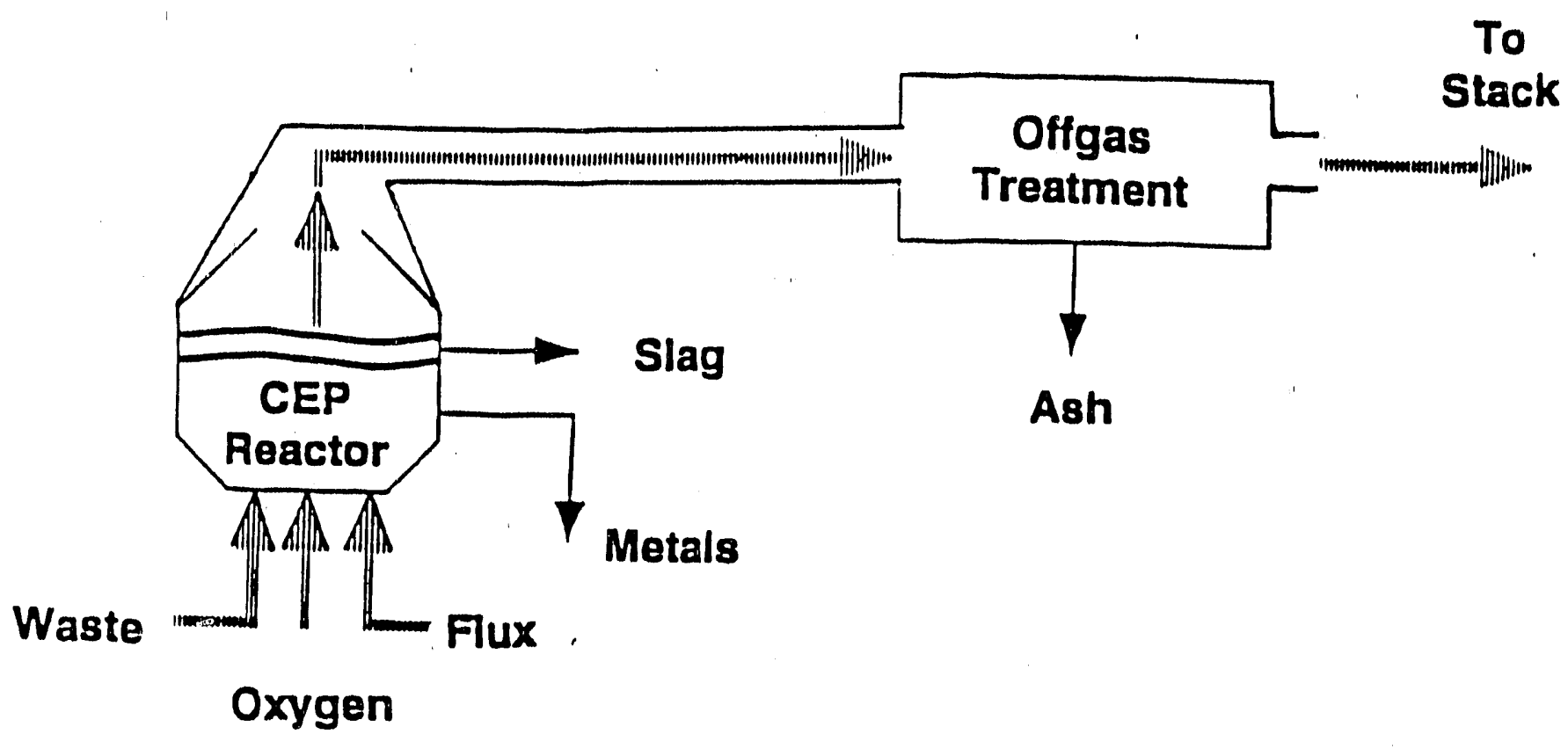

Molten Metal Bath Technology

D-34 


\section{Technology Description}

The fossil fuel hearth melting technology is a thermal smelting technology consisting of a molten slag bath into which metal ore, blast furnace slag, and viher waste materials are introduced. The specific process variation addressed here is an adaptation of a proprietary commercial metal smelting technology, known as "Sirosnclt." The sirosmelt process utilizes a lance through which air and fuel can be injected under the surface of the slag bath. This injection of air fuel mixture creates high turbulence within the bath providing good mixing and combustion of the waste. The system is flexible in producing an oxidizing or reducing environment depending on the waste being processed. Operational temperatures of the molten bath of as much as $1600^{\circ} \mathrm{C}$ destroy the organics and melts the inert fractions into a vitrified slag product. Fluxing agents can be introduced to enhance the process by lowering the melting temperatures of the inorganic mixture. Fine particulate wastes, such as llyash and dusts can be introduced into the bath through the lance while larger particle waste forms are fed through an auxiliary feed port. The resulting slag of melted inert material is removed and cast into 1 to 2 ton blocks.

\section{Past/Current Applications}

Past applications of the hearth melting technology has primarily been in the secondary steel smelting industry. The potential use of the Sirosmelt process in waste treatment applications is in very preliminary stages.

\section{Advantages}

Lance injection of air creates excellent waste/bath mixing for maximum combustion, relatively simple operating concept with few moving parts, high temperatures resulting in high waste destruction efficiencies.

\section{Disadvantages}

High temperatures within the system will volatilize metals and will generate NOx, the high turbulence will cause high particulate carryover, and contamination control problems in a nonscaled lurnace configuration.

g. Lightfoot, B., private communication, Ausmelt Pty. Ltd., Victoria, Australia, May 1991. 


\section{Research Needs}

The primary research need is to develop and demonstrate the operability of the technology as a waste treatment process. The Sirosmelt process has had very limited testing. As with other melting technologies effects of heterogeneous waste streams on slag chemistry and process operations well as fate of heavy metals and radionuclides needs further investigation.

\section{Process Data}

Status: Emerging bench

RCRA Handling Code: T18

Thermal Capacity Range: Low: $0.9 \mathrm{MMBtu} / \mathrm{hr}$

High: $4.5 \mathrm{MMBtu} / \mathrm{hr}$

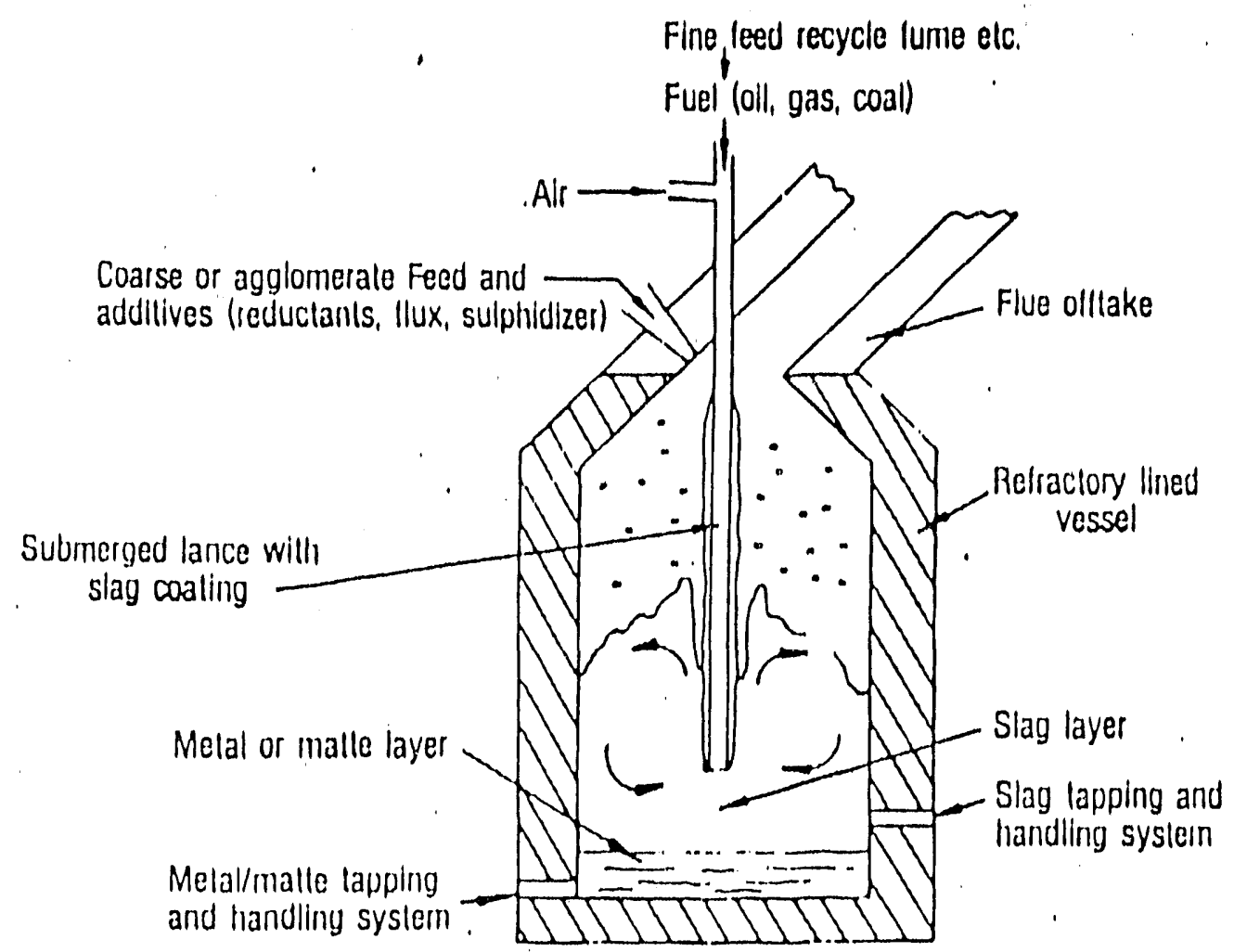

Fossil Fuel Hearth Melter 

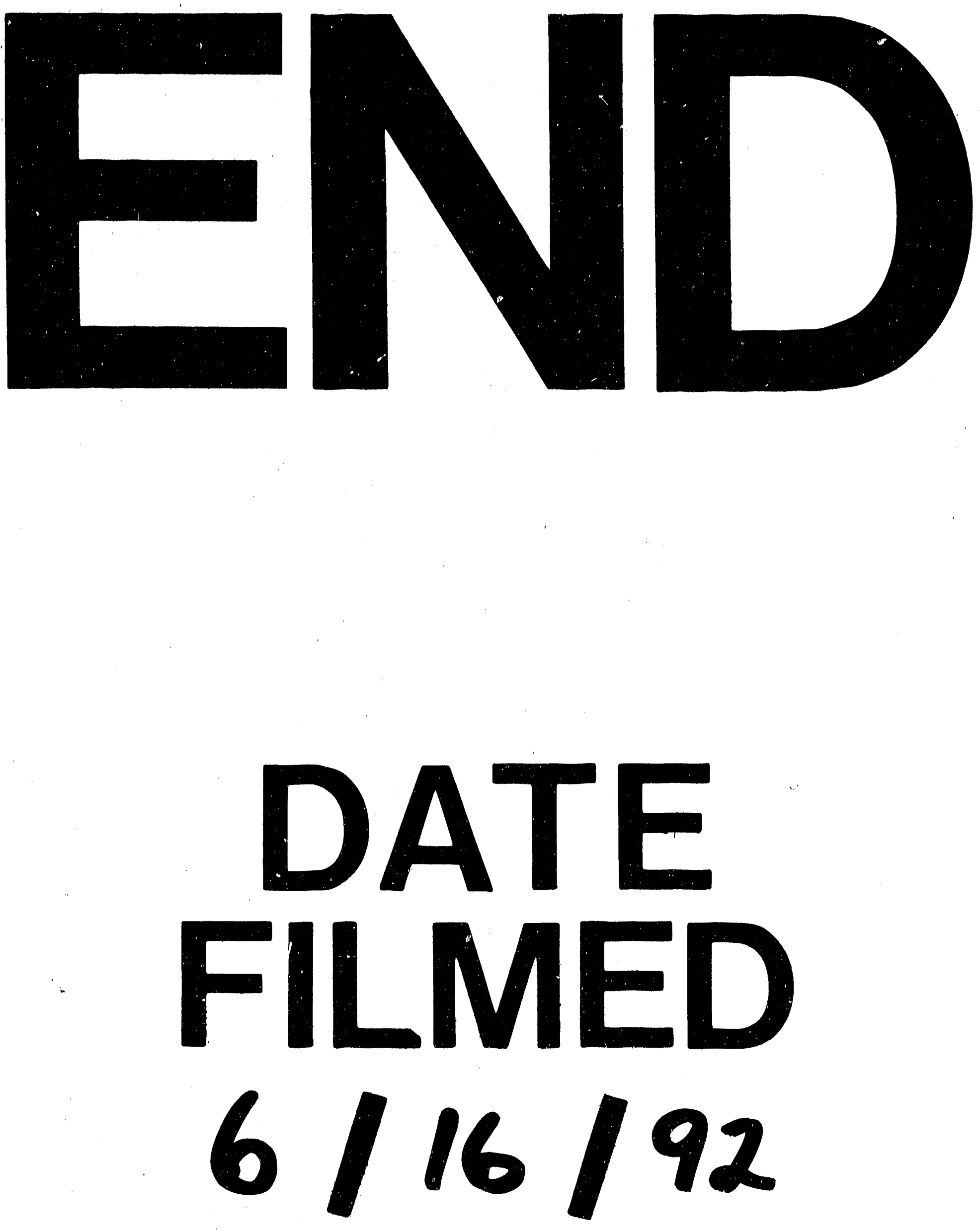

1 
